\title{
INDUSTRIAL POLLUTION IN OTA OGUN STATE, NIGERIA: THE DISCONNECT BETWEEN CITIZEN, INDUSTRY AND GOVERNMENT PERSPECTIVES
}

\author{
by \\ Olalekan Odunewu Onilude \\ BSc Agriculture, University of Ibadan, Nigeria 1990 \\ MSc Agricultural Economics, University of Ibadan, Nigeria 1995 \\ M.InfSc Information Science, University of Ibadan, Nigeria 2005 \\ A thesis
presented to Ryerson University
in partial fulfillment of the requirements for the degree of \\ Master of Applied Science \\ in the Program of Environmental Applied Science and Management
}

Toronto Ontario, Canada, 2015

(C) Olalekan Onilude 2015 


\section{Author's Declaration}

I hereby declare that I am the sole author of this thesis. This is a true copy of the thesis, including any required final revisions, as accepted by my examiners.

I authorize Ryerson University to lend this thesis to other institutions or individuals for the purpose of scholarly research.

I further authorize Ryerson University to reproduce this thesis by photocopying or by other means, in total or in part, at the request of other institutions or individuals for the purpose of scholarly research.

I understand that my thesis may be made electronically available to the public. 
Industrial Pollution in Ota Ogun State, Nigeria: The Disconnect Between Citizen, Industry and Government Perspectives.

Master of Applied Science, 2015

Olalekan Onilude

Environmental Applied Science and Management, Ryerson University

\begin{abstract}
This study examined how residents of Ota, in Ogun State Nigeria, perceive the effects of industrial pollution. It also reviewed the policies that the state government has adopted in controlling and preventing industrial pollution in the past years. Surveys and interviews were used to determine the perceptions of community members and the policy actions of government. The sampling technique used during the survey was purposeful sampling. Data were analyzed through Microsoft Excel and content analysis. Research results showed that residents perceive that industries in Ota pollute the environment a lot. The study also revealed that air pollution through smoke is the major environmental concern for residents in comparison to water and soil pollution. The study revealed that citizens believe the government has not been effective in managing industrial pollution despite its claim that various policy options are being used to address the issue. This study makes recommendations, which could further improve environmental issues in the communities. The successful implementation, monitoring, and enforcement of policies and involvement of residents has the potential to enhance environmental sustainability in Ota.
\end{abstract}




\section{Acknowledgements}

It is a pleasure to acknowledge those who made this thesis possible.

I must first thank my supervisor Dr. Christopher Gore for his consistent guidance and support throughout the period of this study. His constructive criticism was so valuable.

I also want to thank Dr. Michal Bardecki, Director Environmental Applied Science and Management for the department financial assistance during my survey in Nigeria. I want to acknowledge Dr. Mustafa Koc for his encouragement and support since the beginning to the final stage of the program.

I am also grateful to community residents, industry representatives in Ota, and Ogun State Ministry of Environment/Ogun State Environmental Protection Agency officials who were kind enough to share their thoughts and participated in my study.

Thank you to my wonderful and supportive friends Ramesh Lilwah, Emmanuel Ogunjobi and Waad Khogali who were always close by to lend support when needed.

Finally, I owe a great debt of gratitude to my darling wife Yemisi, my children - Olayinka, Oladimeji and Oladoyin, and my mother Esther for their unflinching support during this work and throughout my life. 


\section{Table of Contents}

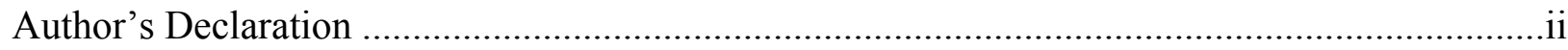

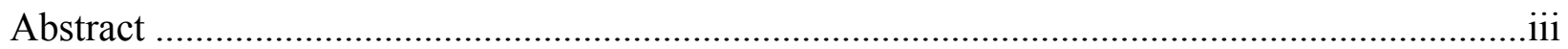

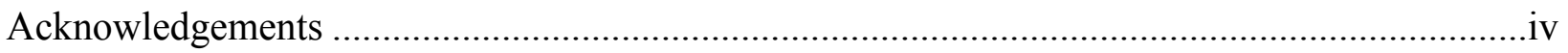

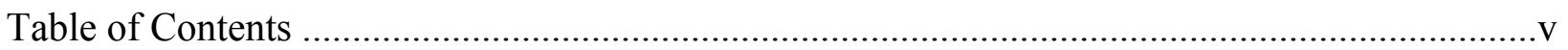

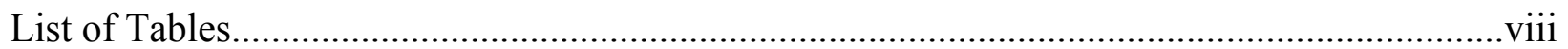

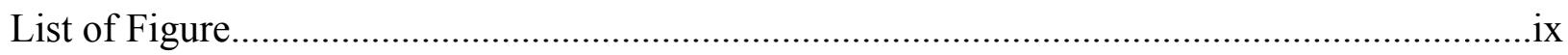

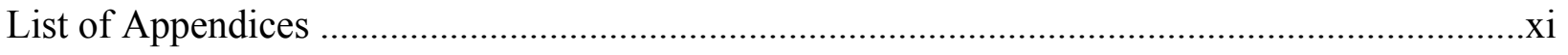

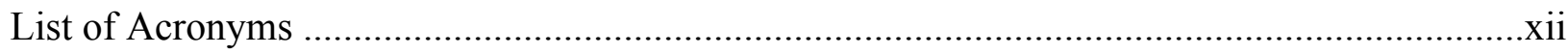

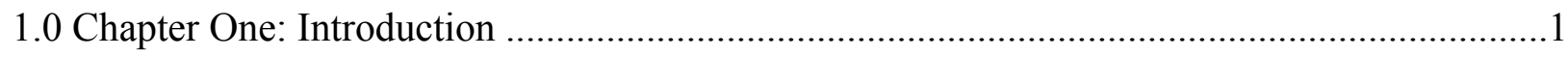

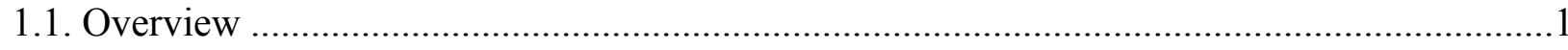

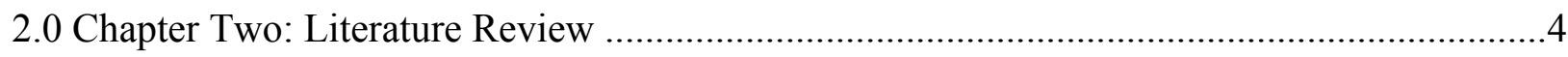

2.1. Historical Background of Environmental Initiatives in Nigeria ...........................................

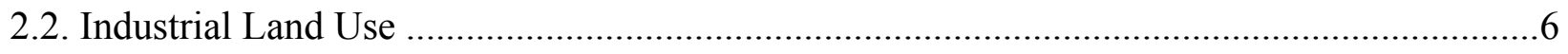

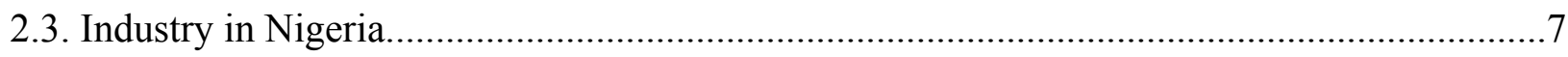

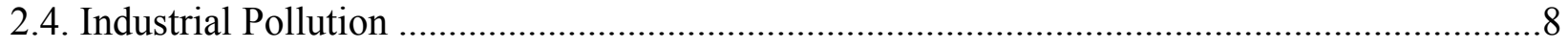

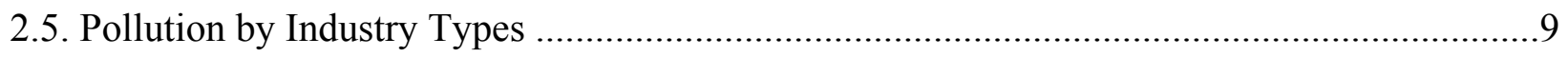

2.6. Industrial Pollution in Nigeria....................................................... 12

2.7. Industrial Pollution and Waste ...................................................... 14

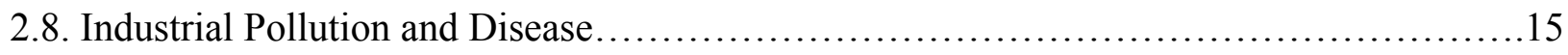

2.9. Environmental Stakeholders......................................................... 


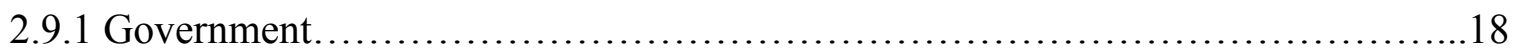

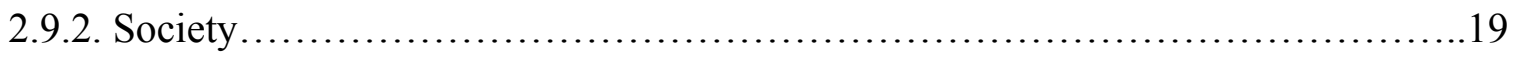

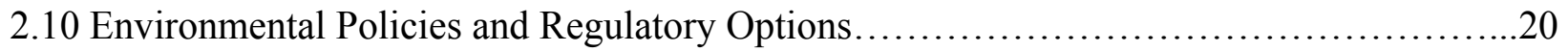

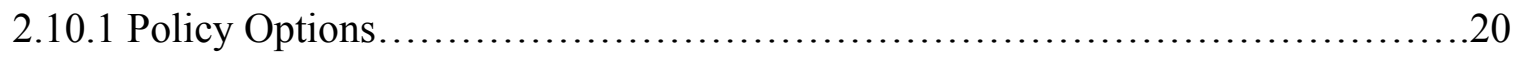

2.10.2 Statutes and Regulations in Nigeria.......................................22

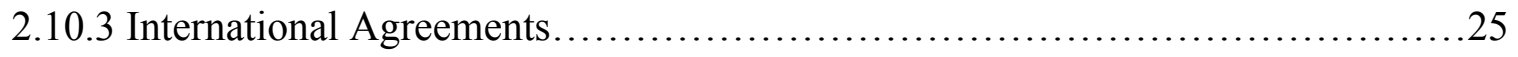

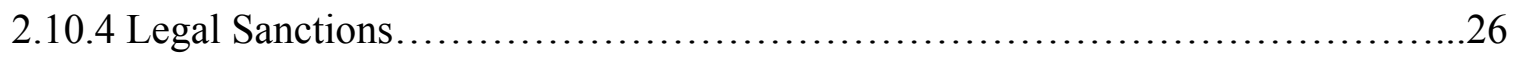

2.10.5 Inadequacies of Nigerian Regulatory Laws.................................27

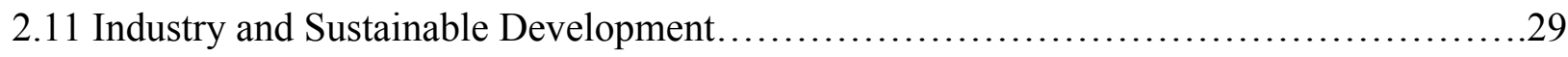

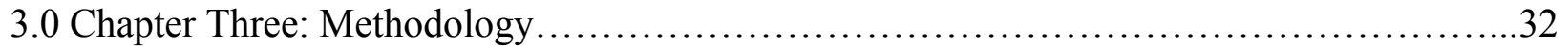

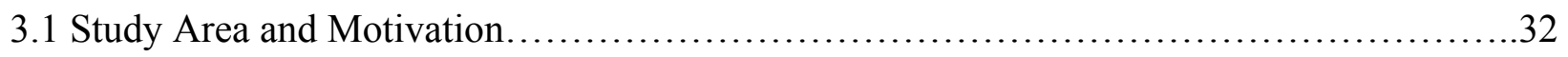

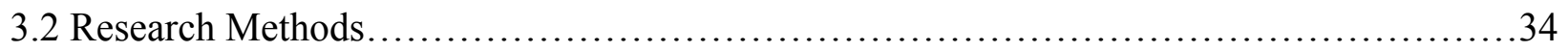

3.2.1 Sampling Technique..........................................................

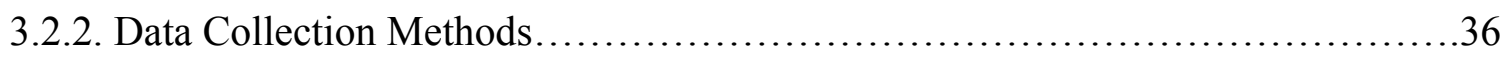

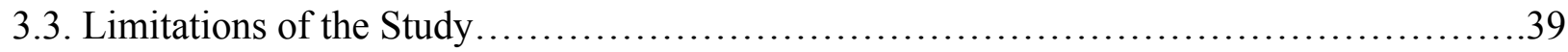

3.4 Statistical Analysis............................................................... 40

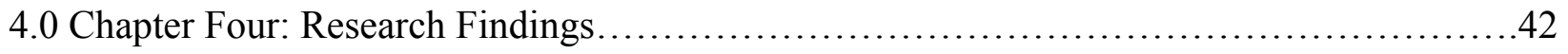

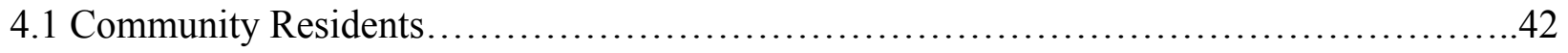

4.1.1 Perceptions of Respondents to Industrial Problems in Ota........................51

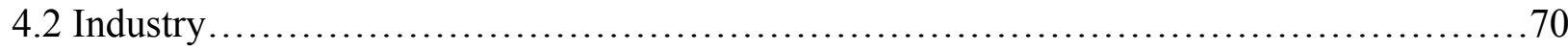

4.2.1 Environmental Concerns/Pollution, Policy initiatives and Corporate Social

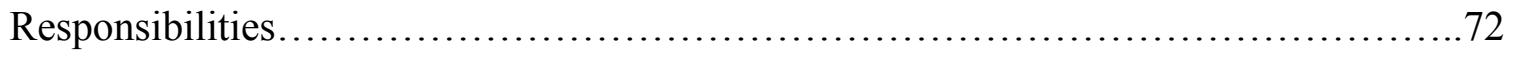

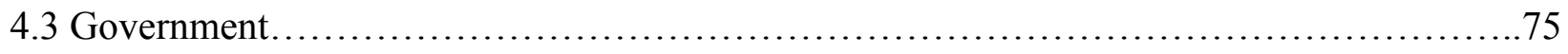


4.3.1 Government officials

4.3.2 Commissioner.................................................... 78

4.4 Overview: Pollution Management in Ogun State.................................... 82

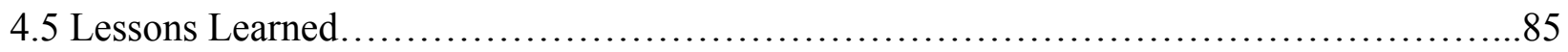

5.0 Chapter Five: Policy Recommendations.......................................... 87

6.0 Chapter Six: Conclusion................................................. 92

Appendices................................................................. 96

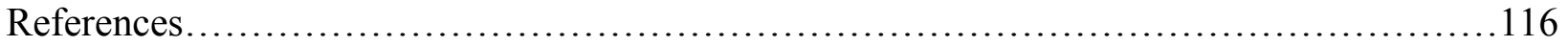




\section{List of Tables}

Table 2.1: Industrial processing plants in Ota Ogun State Nigeria............................7

Table 2.2: Pollutant types from different industries................................... 11

Table 2.3: Total pollution load (PL) to all media by sector in Ota and Agbara Industrial Estates,

Ogun State Nigeria........................................................... 13

Table 2.4: NESREA Compliance Flag Award..............................................24

Table 4.1: Do you think industries near you pollute the environment?..................................52

Table 4.2: Main sources of water/soil pollution.....................................61

Table 4.3: Community development initiatives of companies..........................63

Table 4.4. Information about companies............................................. 71 


\section{List of Figures}

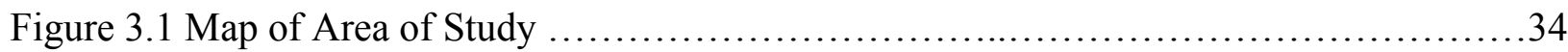

Figure 4.1 Households close to a factory in Ota Industrial Housing Estate......................43

Figure 4.2 Households close to a factory in Ota Township..................................43

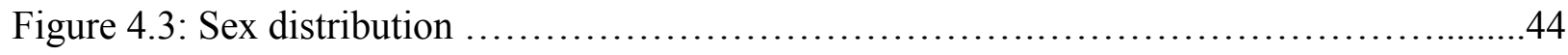

Figure 4.4: Age distribution............................................................ 44

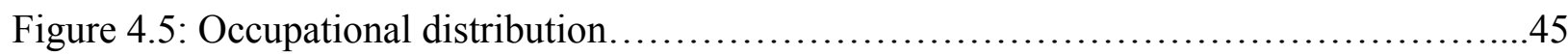

Figure 4.6: Distribution of educational qualification........................................46

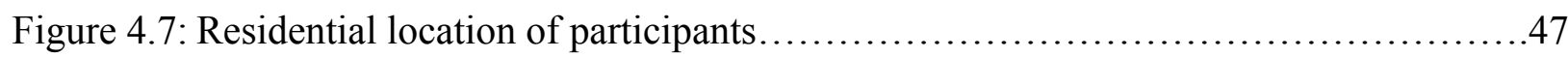

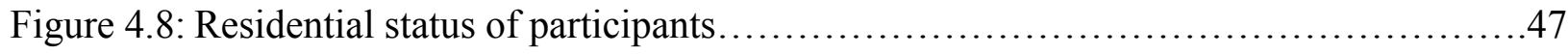

Figure 4.9: Length of residence in the community ........................................48

Figure 4.10: Distance of residence to the nearest industry ....................................49

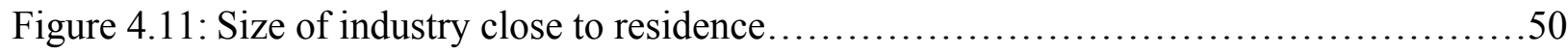

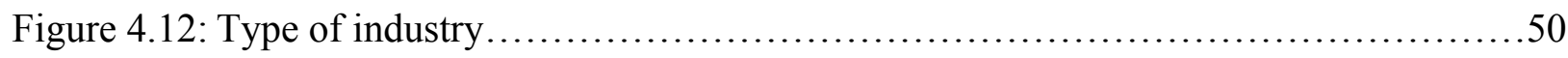

Figure 4.13: Media through which citizens heard about industrial pollution ...................53

Figure 4.14: Level of concern about types of air pollution..................................54

Figure 4.15: Types of air pollution that is of major concern................................55

Figure 4.16: How often about air pollution concern.......................................56

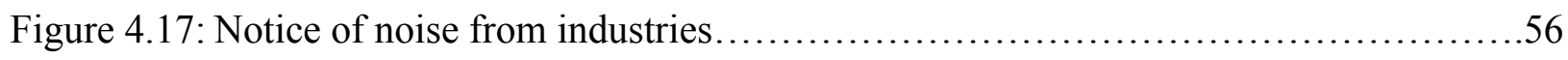

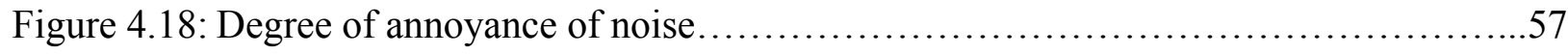

Figure 4.19: Concerns about water pollution............................................5

Figure 4.20: Concerns about soil pollution..........................................6 60 
Figure 4.21: Health (Medical) conditions of respondents..............................61

Figure 4.22: Corporate social responsibility of companies..............................62

Figure 4.23: Procedure to deal with industrial pollution complaints.......................64

Figure 4.24: Person that is reported to during environmental concern......................65

Figure 4.25: Person or group that directs environmental initiatives.........................66

Figure 4.26: Entity with central responsibility of managing pollution.....................67

Figure 4.27: Effectiveness of government in managing industrial pollution..................68

Figure 4.28: Has pollution become better or worse in the last 5 or 10 years?...........................69 


\section{List of Appendices}

Appendix 1: Verbal Recruitment Script - Community Residents ..........................96

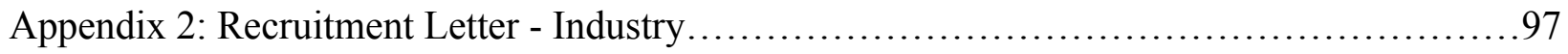

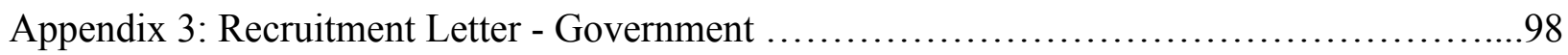

Appendix 4: Consent Agreement Form - Community Residents.............................99

Appendix 5: Consent Agreement Form - Industry................................. 102

Appendix 6: Consent Agreement Form - Government................................. 105

Appendix 7: Survey Questions..................................................... 108

Appendix 8: Interview Guide for Industry.......................................... 114

Appendix 9: Interview Guide for Government/List of Interviews at Ministry of Environment,

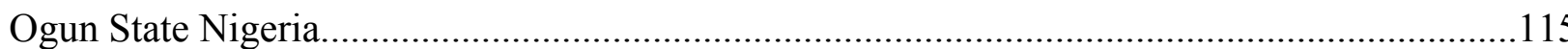




\section{List of Acronyms}

$\begin{array}{ll}\text { CBN } & \text { Central Bank of Nigeria } \\ \text { CBO } & \text { Community Based Organization } \\ \text { CSR } & \text { Corporate Social Responsibility } \\ \text { EMS } & \text { Environmental Management System } \\ \text { FEPA } & \text { Federal Environment Protection Agency } \\ \text { ICMD } & \text { Inspection and Compliance Monitoring Department } \\ \text { IPPS } & \text { Industrial Pollution Projection System } \\ \text { ISO } & \text { International Organization for Standardization } \\ \text { NESREA } & \text { National Environmental Standards and Regulations Enforcement Agency } \\ \text { OGEPA } & \text { Ogun State Environmental Protection Agency } \\ \text { SON } & \text { Standard Organisation of Nigeria } \\ \text { SRS } & \text { Simple Random Sampling } \\ & \text { United Nations Industrial Development Organization }\end{array}$




\section{Chapter 1: Introduction}

\subsection{Overview}

One of the local land uses in urban areas is industrial, sometimes using ten percent of land in a city (Foley et al, 2005). The percentage of industrial land use in any urban area might look small relative to other land uses, but its impact on the socio-economic milieu of the neighbourhood and city can be enormous. Though industrial development offers some opportunities such as employment, roads and other services to the neighbouring communities, the possibilities of adverse effects on the environment also increase if they are not properly controlled or minimized (Adebayo \& Oni, 2011). Nuissl et al. (2009) stated that land use due to industrial development exerts serious environmental pressure on landscapes which inevitably leads to change that has an impact on ecological quality and human health. This is particularly true in parts of the world which are poor and where regulations to control pollution are weak or weakly enforced, such as in many sub-Saharan African countries. This study examines a community effected by industrial pollution in one West African country: the community of Ota, in Ogun State, Nigeria.

Since the 1980s there has been a proliferation of industries in the city of Ota due to its proximity to Lagos (former capital of Nigeria), and the availability of land to accommodate the establishment of industries. The influx and cluster of these industries in close proximity to residential buildings, and the haphazard and scattered manner in which they were sited makes the residents vulnerable to industrial pollution and health hazards. It is in this context that an investigation was proposed to know the environmental problems encountered by Ota community residents who live close to the industries. 
The broad objective of this research, therefore, is to examine how residents perceive the effects of industrial pollution in the city of Ota, in Ogun State, Nigeria. There are two central questions: how do government, industry and residents perceive the effect of industrial pollution in Ota town; and what actions, if any, have been taken to try to address industrial pollution?

The sub-objectives of the study are:

- To examine the extent and the perceived effects of industrial pollutants on neighbouring communities/indigenous people

- To ascertain policies that the state government has adopted in controlling and preventing industrial pollution in the past years.

- To make policy recommendations, and propose areas of further research.

The research findings from this study reveals that while government and corporations claim to be doing a moderate or adequate job managing pollution, residents report a different perspective: they do not receive adequate communication about pollution from firms or government and perceive there is a high level of pollution, particularly air pollution. Therefore, the research shows that there is disconnect between government and corporate positions on pollution management and citizen perceptions.

Chapter 2 provides a background of environmental initiatives in Nigeria, and examines the concept of industrial pollution, industrial pollution in Nigeria, industrial pollution and diseases, environmental stakeholders, environmental policies and regulatory options. Environmental issues and sustainable development are also discussed in relation to Nigeria. Chapter 3 explains the methodology for this study which includes the area of study, approach/methods of data collection, limitations of the study, and method of statistical analysis. 
Chapter 4 discusses the key findings of the study and Chapter 5 provides policy recommendations in addressing industrial pollution in Ota. Chapter 6 concludes the thesis. 


\section{Chapter 2: Literature Review}

\subsection{Historical Background of Environmental Initiatives in Nigeria}

Nigeria is a federal constitutional republic comprising 36 states and its Federal Capital Territory, Abuja. It gained independence October 1st 1960 from the United Kingdom, and it is the most populous country in Africa with approximately 174 million inhabitants. The country is located in West Africa and shares land borders with the Republic of Benin in the west, Chad and Cameroon in the east, and Niger in the north. Its coast in the south lies on the Gulf of Guinea in the Atlantic Ocean. It lies between latitudes $4^{\circ}$ and $14^{\circ} \mathrm{N}$, and longitudes $2^{\circ}$ and $15^{\circ} \mathrm{E}$. Politically, the country regained democracy in 1999 ending almost 33 years of military rule, excluding the short-lived second republic (between 1979 and 1983) (Library of Congress, 2008).

Nigeria has a history of environmental policy that is traceable back to the early postindependence period. It was not until the 1980 s and 1990s that serious attention was given to the protection of the nation's environment. The country's environmental paradigm shift was prompted by the 1987 illegal dumping of toxic wastes, made up principally of polychlorinated biphenyls (PCBs) at the Koko Port, a small town situated in the south of the country. The media reaction that accompanied the discovery hastened the creation of the Federal Environment Protection Agency (FEPA) since Nigeria lacked both the institutional and legal framework to tackle the issue.

In December 1988, as part of an emerging coordinated approach to environmental issues, the Federal Government of Nigeria established FEPA by Decree $58^{1}$ to protect, restore and preserve the ecosystem. The coming of FEPA through the FEPA Act 1988 represented a

\footnotetext{
${ }^{1}$ The decree 58 of 1988 requires FEPA to establish environmental guidelines and standards for the
} 
milestone in environmental management effort in Nigeria. Once the decision was taken to confront the problem of environmental abuse, Nigeria led the fight against hazardous wastes dumping until the signing of the Basal Convention against trans boundary transportation of hazardous, toxic and radioactive wastes in 1989 (Adelegan, 2008). With the setting up of the FEPA (FEPA became the Federal Ministry of Environment in January 2000), State Environmental Protection Agencies (SEPAs) were established by States in the first half of 1990s (Adeoti, 2008). The Ogun State Environmental Protection Agency (OGEPA) complements FEPA's functions at the state level and uses different types of tools and instruments to achieve policy objectives; it also maintains connections with the local government environmental protection agencies (LGEPAs) to monitor environmental conditions at the local level. The role of the Local Governments within Ogun State are: monitoring and enforcing the industrial regulations and standards set by OGEPA; monitoring the environmental conditions in the LG areas; ensuring that all projects with potential environmental impacts within the LG area undergo an Environmental Impact Assessment (EIA) process (Adamson, 1996). Although the LGEPAs are established by law, this tier of government in Ogun State is not active in environmental protection. This assertion is based on the findings of the survey conducted in Ota in 2014.

Nigeria, in recent years, has been witnessing rapid industrial development mostly along its coastal cities. Ogun state is considered to be the Nigeria's current industrial hub with Ota as its largest industrial city (Etim, 2012). The presence of industrial facilities in close proximity to residential houses and the effects of industrial pollution on the communities give cause for concern. 


\subsection{Industrial land use}

Industrial land use is the usage of a piece of land for industrial purposes, and its supply is central to the pattern and process of economic regeneration and restructuring (Adams et al., 1994). Traditionally in Nigeria, land is used primarily for agriculture, but currently it is used for non - agricultural purposes due to population increase and the growth of the industrial economy (Bashorun, 2003). Dempwolf (2009) stated that industrial land uses have traditionally included manufacturing, transportation, warehousing and distribution, and utilities. In most places manufacturing is further divided into heavy and light. For the most part, industrial land uses have always been incompatible with residential and commercial uses. Hall (1988) grouped industrial land use types under eight headings as offices and commercial buildings; factories in urban situations; factories in rural situations; warehousing; transportation; extractive industries; special types of industries e.g. power stations, water reservoirs; and ancillary land uses such as cooling ponds, storage land and recreation.

With respect to Nigeria, Obateru (2004) classified industrial land use into four, namely: crafts making which include cloth (spinning, weaving dyeing), leather crafts, wood and sundry carvings, drums and musical instruments; light (non-manufacturing) industries comprising of printing, publishing, electrical/ auto-servicing and repair; general (manufacturing) industries to include textile mill, paper and beverage industries; and noxious (special) industries consisting of chemical, pharmaceutical and allied products, petroleum refining and associated industries. A cursory look at the classification shows that these industries might have serious environmental effects on the population of the neighbouring communities and the indigenous land owners. 


\subsection{Industry in Nigeria}

Industry plays an important role in the process of economic development of any nation. It improves the economic well-being of citizens and supplies the goods they consume. Business in Nigeria has been classified as small, medium and large. The Central Bank of Nigeria (CBN) (2005), broadly defines the small, medium and large industries as follows: small-scale industry is a business with a labour size of 11-100 workers or a total cost of not more than N50 million, including working capital but excluding cost of land; medium scale is an industry with a labour size of between 101-300 workers or a total cost of over N50 million but not more than N200 million, including working capital but excluding cost of land; large scale is an industry with a labour size of over 300 workers or a total cost of over N200 million, including working capital but excluding cost of land. The Ogun State Government Annual Report (2014) shows that ninety-one industrial processing plants are currently in Ota (Table 2.1) with the corresponding number of each plant:

Table 2.1 Industrial Processing Plants in Ota Ogun State Nigeria

\begin{tabular}{|l|c|}
\hline Types of Industrial Sector & Number of Establishments \\
\hline Food beverage and technology & 26 \\
\hline Chemical and pharmaceuticals & 21 \\
\hline Domestic and industrial plastic, rubber and foam & 16 \\
\hline Basic metal, iron and steel and fabrication metal products & 18 \\
\hline Pulp, paper and paper products, printing and publishing & 7 \\
\hline Wood and wood products & 2 \\
\hline Non-metallic mineral products & 1 \\
\hline Total & 91 \\
\hline
\end{tabular}

Source: Ogun State Annual Report, 2014 


\subsection{Industrial Pollution}

Pollution from industries negatively impacts the neighbouring communities, and poor urban communities are often overlooked by industries and sometimes even the government. Deficient environmental health awareness coupled with lack of sustainable environmental health programs is a major challenge in most developing countries (WHO, 2007). The areas in close proximity to industrial activities are marked by noticeable contamination of air, soil, and water that can ultimately lead to illness and/or harm to the residents in the affected areas (De Bartolomeo et al 2004; Landajo et al 2004; Mir et al 2004). Chapman \& Walker (1991) stated that the impacts of any factory extend beyond its boundary fence; the impacts may be beneficial or harmful to the surrounding community. On the positive side, income generated by employment and trade in the industry will have a multiplier effect on the local community as money circulates through the economic system, boosting trades and business. Negative impacts of industrial location are of greater concern from a welfare point of view because the community land owners are often neglected in evaluating the costs and benefits of industrial development. MacDonell, Morgan and Newland (2002) stated that environmental solutions could be realized through the involvement of affected communities in the decision process to broaden support and improve progress. Without the support of local groups, making cleanup decisions can be difficult at best, and in some cases actions have been delayed for years when not effectively coordinated with community members. The implementation of community involvement programs for cleanup projects are forms of environmental education that build capacity in the general population to participate in environmental studies and decisions. At the same time, there is a burden on industry and government to take the lead in managing or eliminating pollution. 
Puga and Venables (1996) posited that there is no consensus about whether small scale industries are more pollution-intensive than large-scale industries. Some scholars argue that small scale industries may be more environmentally sustainable because of such factors as informal community pressure and regulation. But there are also contrary opinions. Braden (1994) stated that small scale industries "often pollute more per unit of output than large firms operating in the same sector." This has been attributed to their failure to employ more efficient, updated technology; the difficulty of monitoring their compliance with regulations; their inability to safely dispose of their wastes; and their limited awareness of the potentially harmful effects of their activities. In the late 1990 s, approximately $70 \%$ of total global pollution (Smith \& Kemp, 1998) and $60 \%$ of carbon emissions (Marshall, 1998) were produced by SMEs. A study by Hillary (2000) showed that the total negative environmental impact from SMEs outweighs the combined environmental impact of large firms.

\subsection{Pollution by Industry Types}

There are several different types of industrial pollution. Severe metal pollution has been reported from areas surrounding mines and smelters in many countries (Martley et al, 2004; McMartin, et al, 2002; Rawlins, et al, 2006). Heavy metals have been seen as a major toxic substances released by industrial activities. Unlike organic pollutants which may degrade to less harmful components as a result of biological or chemical processes, metals such as lead, cadmium, copper, and manganese are not degradable and their effects on local environments and organisms may therefore be substantial and long lasting in spite of extensive remediation efforts (Amiard, et al, 1995). In most parts of the world, large quantities of trace metals are directly discharged to nearby agricultural lands and into surface waters and taken up by food crops (Perez-Sirvent et al, 2007). In recent years, many governments and policy makers have continued 
to strive for a more comprehensive understanding of environmental health hazards due to intensive industrial activities in order to inform future policy and abatement legislation (Parikh et al, 1995). Chemical and petrochemical industries have been identified as large emitters of not only metals but also a wide variety of pollutants (e.g., volatile organic compounds (VOCs), polycyclic aromatic hydrocarbons (PAHs), polychlorinated biphenyls (PCBs); these pollutants cause some adverse health effects in people living nearby (Nadal et al, 2009). Textile industries can act as one of the major sources of metal pollution in the environment (Deepali \& Gangwar, 2010). Solid and liquid wastes emanating from the leather/tanning industry are known to contain various toxic trace metals (McMartin, et al, 1999). In most developing countries, tannery effluents are directly discharged to nearby land where they adversely affect the quality of both soil and ground water (Kashem \& Singh, 1999). Non-metallic mineral industries such as cement, ceramic, and battery manufacturing facilities can act as a major source of trace metal pollution in soil (Al-Khashman \& Shawabkeh, 2006).

In recent years, researchers have analyzed the relationship between environmental damage and the growth of industries in developing countries. According to Scott (1998), the environmental impacts of the industries in the developing world have been ignored, and there is little evidence available on environmental impact and sustainability of such industries to guide decision makers. Wen (n.d.) posited that industrial pollution is more heterogeneous and complex in developing countries. The author identified that the situation is due to low level of technology in industrial processes in this part of the world. It was also reported that air pollution emissions can be caused for technical reasons, and unsuitable, worn-out or defective facility components. Wen (n.d.) argued that pollutants from industries are divided into three major categories namely gas, solid and water; other pollutant forms include noise and odour. 
Table 2.2. Pollutant types from different industries

\begin{tabular}{|c|c|c|c|c|}
\hline \multirow{2}{*}{$\begin{array}{l}\text { Industrial } \\
\text { Sectors }\end{array}$} & \multicolumn{4}{|c|}{ Pollutant forms } \\
\hline & Gas & $\begin{array}{l}\text { Solid waste and } \\
\text { soils }\end{array}$ & Water & Others \\
\hline Iron and Steel & $\begin{array}{ll}\mathrm{SO}_{\mathrm{X}}, \mathrm{NO}_{\mathrm{X}}, \mathrm{HC}, \\
\mathrm{CO}, \mathrm{H}_{2} \mathrm{~S}, \text { Toxic } \\
\text { chemicals }\end{array}$ & $\begin{array}{lr}\text { Slag, wastes, } \\
\text { sludge } \\
\text { effluent treatment }\end{array}$ & $\begin{array}{l}\text { BOD, COD, oil, } \\
\text { metals, acids, } \\
\text { phenol, cyanide }\end{array}$ & Noise, particulate \\
\hline $\begin{array}{l}\text { Textiles and } \\
\text { Leather }\end{array}$ & $\mathrm{SO}_{\mathrm{X}}, \mathrm{HC}$ & $\begin{array}{l}\text { Sludge } \\
\text { (Chromium) from } \\
\text { effluent treatment }\end{array}$ & $\begin{array}{l}\text { BOD, solids, } \\
\text { sulfates and } \\
\text { chromium, dyes }\end{array}$ & $\begin{array}{l}\text { Odour, noise, } \\
\text { particulate }\end{array}$ \\
\hline Pulp and Paper & $\mathrm{SO}_{\mathrm{X}}, \mathrm{NO}_{\mathrm{X}}$ & $\begin{array}{l}\text { Sludge from } \\
\text { effluent treatment }\end{array}$ & $\begin{array}{l}\text { BOD, COD, } \\
\text { solids, chlorinated } \\
\text { organic } \\
\text { compounds }\end{array}$ & $\begin{array}{l}\text { Noise, odour, } \\
\text { particulate }\end{array}$ \\
\hline Petrochemicals & $\begin{array}{ll}\mathrm{SO}_{\mathrm{X}}, \mathrm{NO}_{\mathrm{X}}, & \mathrm{HC}, \\
\mathrm{CO}, \mathrm{H}_{2} \mathrm{~S} \text { Toxic } \\
\text { chemicals }\end{array}$ & $\begin{array}{l}\text { Spent catalysts, } \\
\text { tars, sludge }\end{array}$ & $\begin{array}{ll}\text { BOD, COD, oil, } \\
\text { phenols } \\
\text { chromium }\end{array}$ & $\begin{array}{l}\text { Noise, odour, } \\
\text { particulate }\end{array}$ \\
\hline Chemicals & Organic chemicals & $\begin{array}{ll}\text { Sludge from } \\
\text { pollution } \\
\text { treatment and } \\
\text { process waste }\end{array}$ & $\begin{array}{l}\text { COD, organic } \\
\text { chemicals, heavy } \\
\text { metals, solids and } \\
\text { cyanide }\end{array}$ & $\begin{array}{l}\text { Odour, } \\
\text { chemicals }\end{array}$ \\
\hline
\end{tabular}

Source: Wen, X. (n.d.).

Industries in developing countries have few incentives to invest in pollution control because of lack of funds, weak regulation and oversight. Also, there is lack of necessary information to set priorities, strategies, and action plans on environmental issues. Plant-level monitoring of air, water and toxic emissions are deficient; data collection are problematic, and there is usually a lack of trained personnel on industrial sites. The lack of data prompted the World Bank to develop the Industrial Pollution Projection System (IPPS) as a tool to better understand the levels of pollution and policy development in developing countries (Aguayo, Gallagher, and Gohzalez 2001; Oketola and Osibanjo, 2007). 


\subsection{Industrial Pollution in Nigeria}

There is a high rate of atmospheric pollution especially in industrial areas in Nigeria. For example, the air over Lagos, where about $38 \%$ of the manufacturing industries in the country are located, has been credited with characteristic unpleasant odour (Nwachukwu and Ugwuanyi, 2010; Osuji and Avwiri, 2005). Also, environmental pollution has been seen as a constant problem in Nigeria especially in the Niger Delta region of the country. This region has recorded several cases of the effect of pollution such as gas flaring, and oil spillage in their environment due to pervasive presence and operation of oil and gas companies (Nduka and Orisakwe, 2009). Research conducted by Adebowale et al (2011) to investigate the effect of industrial water pollution on the livelihood of rural dwellers in Ado Odo/Ota and Yewa South Local Government areas, Ogun State showed that the impact of industrial water pollution is highest in Ado Odo Ota where effluent from industries had damaged their water resources and affected their livelihood a great deal. In Yewa South Local Government Area, the majority of the rural dwellers did not believe that industrial activities have impact on their stream because there are virtually no industries in that area.

According to Magbagbeola (2001), industrial pollution is a major environmental problem in Nigeria. It arises from lack of proper control of pollutant industries. The author stated that most industries that have the potential to seriously degrade the environment are mainly based in urban areas. Research findings from Etim (2012) and Odesanya et al. (2012) show that these kinds of pollution are relevant to the Nigerian context because there are different industrial processing plants such as chemical, pharmaceutical, plastics, paper and printing, and metal and steel industries located in close proximity to residential buildings in Ota that generate pollutants. 
One of the dominant ways that industrial pollution is controlled and regulated is by implementing environmental policies and regulations. The IPPS was used by Odesanya et al (2012) to estimate the pollution load to all media - (air, toxic chemical, toxic metal, and water) of industries in Ota and Agbara estates of Ogun state. The result is presented in Table 2.3 below.

Table 2.3. Total pollution load (PL) to all media by sector in Ota and Agbara Industrial Estates, Ogun State Nigeria

\begin{tabular}{|l|l|l|l|l|l|l|}
\hline Sector & PL(air) & $\begin{array}{l}\text { PL(Toxic } \\
\text { Chemical) }\end{array}$ & $\begin{array}{l}\text { PL(Toxic } \\
\text { Metal) }\end{array}$ & PL(Water) & $\begin{array}{l}\text { Total } \\
\text { Pollution } \\
\text { Load }\end{array}$ & $\begin{array}{l}\text { \%ontribution } \\
\text { Cod }\end{array}$ \\
\hline $\begin{array}{l}\text { Food, Beverage and } \\
\text { Tobacco }\end{array}$ & 20658.44 & 698.97 & 0.30384 & 6063.195 & 27420.91 & 11.81 \\
\hline $\begin{array}{l}\text { Wood and Wood } \\
\text { Products }\end{array}$ & 262.79 & 22.58 & 0.34664 & 5.937907 & 291.6536 & 0.13 \\
\hline $\begin{array}{l}\text { Paper and Pulp } \\
\text { products }\end{array}$ & 410.22 & 41.44 & 0.164123 & 305.2986 & 757.1199 & 0.33 \\
\hline $\begin{array}{l}\text { Chemicals and } \\
\text { Pharmaceuticals }\end{array}$ & 90799.65 & 17961.53 & 402.3281 & 10468.4 & 119631.9 & 51.52 \\
\hline $\begin{array}{l}\text { Non-metallic } \\
\text { Mineral Products }\end{array}$ & 344.20 & 1.65 & 0.144812 & 2.237863 & 348.2343 & 0.15 \\
\hline $\begin{array}{l}\text { Domestic and } \\
\text { Industrial Plastics }\end{array}$ & 3527.68 & 1265.71 & 0.144812 & 210.4198 & 5051.91 & 2.18 \\
\hline $\begin{array}{l}\text { Electrical and } \\
\text { Electronic sector }\end{array}$ & 21.53 & 6.19 & 8.46198 & 1.60077 & 37.78803 & 0.02 \\
\hline Basic Metal & 27960.7 & 4950.02 & 2133.273 & 43511.59 & 78555.58 & 33.84 \\
\hline $\begin{array}{l}\text { Motor vehicle } \\
\text { assembly }\end{array}$ & 76.29 & 14.83 & 0.691783 & 0.255809 & 92.0722 & 0.04 \\
\hline Source: Ods & & & & & \\
\hline
\end{tabular}

Source: Odesanya et al (2012).

The result of the study shows that Chemicals and Pharmaceuticals is the most polluting sector with a total pollution load of 119631.9 ton/year or $51.52 \%$ of the emissions followed by Basic Metal with a total contribution of $33.83 \%$ (78555.58 ton/year). The next highest polluting sector is Food, Beverage and Tobacco with a total pollution load of 27420.91 ton/year (11.81\%) 
and Domestic and Industrial Plastics with a contribution of 5051.91 ton/year $(2.18 \%)$. All the other sectors contribute negligibly to pollution load, with Electrical and Electronic sector as the least polluting sector.

Dasgupta, Lucas, and Wheeler (2000) used data from Brazil and Mexico to analyze relationships linking economic development, the size distribution of manufacturing plants, and exposure to industrial pollution. Based on their findings, they posited that the IPPS estimates were not an alternative to proper monitoring of pollution sources but aimed to provide regulatory agencies with information that could help them to prioritize the monitoring effort and more efficient allocation of resources (Dasgupta et al 2000).

\subsection{Industrial Pollution and Waste}

Industrial pollution and waste can be understood as the full range of unwanted substances and externalities generated by industrial activities, including emissions to air or surface waters and the substances sent to sewage treatment plants, deposited in landfills, released or applied to the land, treated, injected underground, controlled through storage, recycled or burned for energy recovery (The North American Mosaic 2008). This pollution and waste can be classified into six categories: toxic chemicals, criteria air contaminants, greenhouse gases, hazardous wastes, nonhazardous wastes and radioactive wastes.

Industrial pollution and waste pose potential threats to human and ecological health if not properly managed. The concerns range from toxic effects on fetuses and children to the health implications of low-level exposures to multiple pollutants and the degradation of habitats and ecosystems. Some pollutants can travel long distances and waste is shipped to recycling and disposal sites across political boundaries (The North American Mosaic, 2008). 
There are also important economic costs from industrial pollution which include paying to clean up contaminated sites, regulating waste-generating industries and ensuring medical treatment for the adverse effects of environmental exposures. The non-monetary costs include the depletion of non-renewable resources, consumptive land use and degradation of ecosystems. These factors contribute in no small way to the impact of environmental pollution on overall human and ecological well-being.

\subsection{Industrial Pollution and Disease}

Industrial activities are also a major source of air, water and land pollution, leading to illness and loss of life all over the world. The World Health Organisation (2005) stated that the proportion of the global burden of disease associated with environmental pollution hazards ranges from 23 percent to 30 percent. These diseases include infectious diseases, respiratory diseases and vector borne diseases, each contributing approximately 6 percent to the global burden of disease. The World Health Organisation estimated that outdoor air pollution contributes 0.6 to 1.4 percent of the burden of disease in developing regions especially Nigeria, and other pollution from water, air, and soil, may contribute 0.9 percent.

Samet (2000) identified that pollutants affect human health in numerous ways. For example, exposure to too much smoke, fumes or dust evokes a burning sensation in the airways, tightness in the chest and possible suffocation. Also, asbestos fibres can penetrate deep into lung tissue and evoke reactions, and it might take years for the illness to manifest. In 1991, the World Bank wrote that, "water related diseases are the most important health problem in Ogun State and the most critical health issue linked with environmental degradation" (World Bank Report Republic of Nigeria, 1991). 
In Nigeria,, a study conducted by Aribigbola et al (2012) to examine the health and environmental challenges encountered by the community residents of Ewekoro, Ogun State Nigeria, due to the siting of the Cement Industry in their neighbourhood confirmed the extensive incidence of land, air, and noise pollution over and above recommended minimum limits. Also it was discovered that four diseases (asthma, heart disease, skin cancer and diarrhea) were associated with the area as a result of the proximity of the cement factory to their homes.

In a related research conducted by Oyinloye (2015) on environmental pollution and health risks of residents living near Lafarge Cement Factory, Ewekoro, Ogun State Nigeria, it is confirmed that air pollution is the major environmental problem experienced in the community. Although, water bodies are contaminated and unsuitable for domestic and agricultural purposes due to the effects of pollution from the cement factory. Again, research result shows that asthma is the major health challenge in the community because the residents are exposed to dust during production process. Other diseases reported are cough, heart diseases and skin cancer.

Fatima et al. (2013) conducted research in Sheikhupura, an industrial city in Pakistan to assess the awareness of people about industrial air pollution and its effects on human's respiratory system. The result showed that people who resided near industrial areas were affected more with diseases such as asthma and lung cancer due to industrial air pollution than those who lived far away from industries. Also, a majority of people faced respiratory health problems, and hurdles in their routine work and social life due to industrial smoke. The WHO (2004a) and Ugwuanyi and Obi (2002) listed other diseases associated with industrial air pollution in Nigeria to include: pulmonary tuberculosis, pneumonia, eye and nasal irritation, chronic anoxia due to carbon monoxide, weakness, headache and nausea. 
According to Rumcher et al. (2004); Suh et al., (2000), there is growing evidence that chronic exposure to Volatile Organic Compounds (VOCs) have adverse health effects on humans. Kim et al. (2002) and Kerbachi et al. (2006) stated that the short term adverse effects of VOCs include conjunctive irritation, nose and throat discomfort, headache and sleeplessness, allergic skin reaction, nausea, fatigue and dizziness. The authors identified the long term adverse effects as loss of coordination, leukemia, anaemia, cancer, and damage to liver, kidney and central nervous system. Research conducted by Ojiodu (2013) on VOCs pollution in Isolo Industrial Area of Lagos Nigeria revealed that the major sources of VOCs in the industrial area are mainly anthropogenic, and that Industrial emissions were identified as the major sources of VOCs.

It is evident from the literature and research findings that pollution by industries has adverse effects on the immediate environment and well-being of the public in Nigeria. It is pertinent to further discuss about various stakeholders that are involved or are affected by industrial pollution.

\subsection{Environmental Stakeholders}

Stakeholders can influence companies in a number of ways and to various extents. The management of industries need to understand and integrate the stakeholders to ensure relatively stable environments and long-terms success of the firm (Freeman \& Mcvea, 2001). Freeman is one of the pioneers of stakeholders theory; the author came up with broad and narrow definitions of stakeholders: the broad definition suggests that stakeholders are "any group or individual that can affect or is affected by the achievements of the organizations objectives"; the narrower definition describes stakeholders as "groups who are vital to the survival and success of the

company" (Freeman, 2002, p. 41). Stakeholders could be primary and secondary. Primary 
stakeholders are those that the company cannot survive without, such as shareholders, employees, customers and suppliers (Clarkson, 1995). Their formal relationships with firms have a great influence on a company's environmental strategy success or failure (Buzzelli, 1991). Clarkson (1995) argued that secondary stakeholders include those that affect or are affected by the company, but are not "engaged in transactions with the corporation and are not essential for its survival", such as media and other interest groups. They have the ability to influence both the public opinion and the company in a positive or negative way, but the company does not depend on them as in the case for the primary stakeholders. In this study, secondary stakeholder best matches the situation because the groups that are involved or are affected by industrial pollution are community residents, government regulators and social/community-based organisations.

Henriques and Sadorsky (1999) argued that a firm's level of environmental activeness is related to the pressure it receives from the organizational and community stakeholders, i.e. customers, suppliers, employees, shareholders and for example NGO's and other social groups. The authors also suggested that environmental reactivity is related to high pressure from governments and media.

\subsubsection{Government}

Government is considered to be one of the most influential stakeholders in industrial pollution. Government regulations can exert a great power on industries, and if companies do not meet requirements, fines and penalties are imposed as consequences, which in turn have led companies to adapt and respect the environment more (Fraj-Andrés et al., 2009). Wong et al. (1996) found that environmental regulation represent a major force encouraging firms to invest in more harmless environmental technologies. Menon and Menon (1997) further suggested that firms acting in highly regulated industries are more likely to develop environmental strategies to 
keep their competitive position. Moreover, Saha and Darnton (2005) argued that environmental regulation represents a major pressure for firms to adopt an environmental strategy. The Inspection and Compliance Monitoring Department (ICMD) of the Ogun State Environmental Protection Agency in the Ministry of Environment is the body that monitors and enforces the industrial environmental regulations in Ogun State. It is the duty of the inspectors to visit the facility to ensure compliance of the industries in Ota with environmental regulations, and submit the report of their activities to the General Manager of the agency.

\subsubsection{Society}

Fraj-Andrés et al. (2009) said that corporations act towards social values to achieve a social image. "Size does make a difference since the greater scale, complexity and potential to pollute of many large companies' operations means that a site is more visible and more likely to attract public interest if any problems are caused" (Baylis et al., 1998, p. 289). Esty and Winston (2009) stated that firms that do not pay attention to the local community are prone to future problems. Shrivastava (1995) stated that corporate social responsibility (CSR) play a major role in the welfare of the people. The author said the society will be better off if the industries are strong defenders of the environment because they possess organizational capacity for environmental protection. There is the need for community residents to place responsibilities on industries; monitor, challenge, and establish checks and balances on them to ensure an acceptable level of environmental performance.

In Nigeria, it is clear firms do not address environmental concerns. A good example is the oil industry in the Niger Delta region of the country. According to Idemudia and Ite (2006), despite the fact that the oil industry in Nigeria is predominantly located within the Niger Delta region, there is high incidence of poverty because of environmental degradation. This has 
culminated in violent conflicts between host communities and oil companies. Orubu et al., (2004) stated that structural and institutional factors within Nigeria have made community participation in the decision-making process within the oil industry extremely difficult. Local communities were marginalized and excluded as stakeholders of the oil industries, while they continued to bear the burden of oil production.

Egbu (2000) asserted that some community based organisations have made invaluable contributions towards achieving an effective environmental control and management system. For instance, the outcry from the Finima community, in Bonny, River State, concerning land devastation and lack of Environmental Impact Assessment report by Mobil Producing Nigeria Limited in 1996, prompted FEPA to intervene and monitor the project site.

In this study, the Ota community members (stakeholders) include the civil servants, factory workers, artisans, farmers and traders who collaborate to protect the public interest against industrial pollution in their neighbourhoods through community development efforts.

\subsection{Environmental Policies and Regulatory Options}

\subsubsection{Policy Options}

Policy is a course of action or principle adopted or proposed by a government, party, business or individual. According to Greenbaum and Wellington (2010), a policy incorporates broad goals, procedures, techniques, strategies or tools. Policy instruments are specific methods or tools used by governments to achieve their policy goals and guide the present and future decision making; policy instruments and programs operationalize policy goals. The major categories of environmental policy instruments include: command and control regulations; economic instruments such as tradable pollution permits, pollution taxes and subsidies; voluntary 
measures; and persuasion (Ibid p. 240). The command-penalty is the most common instrument, and it creates a rule prohibiting an activity and imposes penalties for a violation of the rule. Examples of these regulations include: bans and phase-outs of particular substances or kinds of activities. Responses to violations may include forbearance or negotiation; non-penal administrative remedies; quasi-criminal prosecution, and administrative monetary penalties ( $\mathrm{p}$. 241).

In Nigeria, Adeoti (2008) argued that the present approach to industrial pollution control is 'command and control'. The author also posited that the mechanisms for using economic instruments are at present practically non-existent. Medupin and Adedoyin (n.d.) argued that the voluntary measures used by some companies to minimize their harmful effects on the environment is the international industry Environmental Management System (EMS) ${ }^{2}$ standards, e.g. ISO 14000 series. This system is administered by the standard organisation of Nigeria (SON). According to ISO Project Overview (2010), ISO 26000 is another initiative that has already been adopted in Nigeria to guide industries to operate in a socially responsible manner without jeopardizing the environment. This means acting in an ethical and transparent manner that contributes to the environment and well-being of the society. It has seven core expectations: organizational governance, community involvement and development, human rights, labour practices, the environment, fair operating practices and consumer issues. ISO 26000 contains voluntary guidance, not requirements, and it is not a certification standard like ISO 9001: 2008 and ISO 14000:2004. Alli (2013) reported in the Vanguard Newspaper that 33 organisations in

\footnotetext{
${ }^{2}$ An Environmental Management System (EMS) is "a framework that helps a company achieve its environmental goals through consistent control of its operations. It also helps a company address its regulatory demands in a systematic and cost-effective manner. This approach can help reduce the risk of non-compliance and improve health and safety practices for employees and the public." US Environmental Protection Agency Glossary, http://www.epa.gov/ems/
} 
Nigeria have adopted the ISO 26000 standard for use in their operations. The Organisations include Etisalat Nigeria, Nigeria Breweries, Guinness, Federal Inland Revenue Services, Nestle, Unilever; Ashaka Cement, Keystone Bank, First Bank, Access Bank, Diamond Bank, Thistle Praxis Consulting Ltd, and so on. Also, the National Environmental Regulations in Nigeria state that every industrial property should have a sustainable community relations programme as part of demonstration of compliance with Corporate Social Responsibility (CSR).

In Nigeria context, Ogundele (2005) argued that when a government lacks the ability to persuade corporations operating in a particular locality to adopt socially responsible practices to address environmental degradation, the inhabitants of such a community may adopt strategies to ensure compliance. For example, in the oil rich Niger Delta region of Nigeria, the strategies used by the militant groups to fight the multinational companies against environmental degradation were protests, kidnapping of both foreign and indigenous oil staff, and damage to oil installations. Okafor et al (2008) in a study titled "Environmental Issues and Corporate Social Responsibility: The Nigeria Experience" argued that the creation of a better social environment benefits both society and business. "Society benefits through better economic conditions and employment opportunities, while corporate organisations gain from a better community, since the community is the source of its human and natural resources and the consumer of its products and services".

\subsubsection{Statutes and Regulations in Nigeria}

The National Environmental Standards and Regulations Enforcement Agency (NESREA) is the lead environmental agency charged with the protection and development of the environment, biodiversity conservation and sustainable natural resources in Nigeria. NESREA 
was established by NESREA Act 2007, and this superseded the FEPA Act (1988) ${ }^{3}$. The FEPA Act and Regulations were repealed due to lack of or weak enforcement of existing environmental laws and regulations (Ladan, 2012). The 2007 NESREA Act and Regulations aimed to address the preponderance of obsolete environmental regulations, standards and enforcement mechanisms, which resulted, over the years, in the high rates of non-compliance with environmental laws and regulations (ibid). Section 34(c) of the NESREA statute empowers the Minister to make regulations 'generally for the purposes of carrying out or giving full effect to the functions of the Agency' under the Act.

The following regulations that relate to industrial pollution were passed in 2009: National Environmental (Sanitation and Wastes Control) Regulations; National Environmental (Food, Beverages and Tobacco Sector) Regulations; National Environmental (Textile, Wearing Apparel, Leather and Footwear Industry) Regulations; National Environmental (Noise Standards and Control) Regulations; and National Environmental (Chemical, Pharmaceutical, Soap and Detergent Manufacturing Industries) Regulations. In 2011, National Environmental (Electrical/Electronic Sector) Regulations; National Regulations (Non-Metallic Minerals Manufacturing Industries Sector) Regulations; National Environmental (Base Metals, Iron and Steel Manufacturing/Recycling Industries Sector) Regulations; and National Environmental (Domestic and Industrial Plastic, Rubber and Foam Sector) Regulations came into existence (Okorodudu-Fubara, 2012). Some features of these regulations relevant to ensure effective compliance, monitoring and enforcement include: the adoption of a licensing and permit system; the inclusion of the polluter pays principle; the use of environmental management plans; the installation of anti-pollution equipment to meet the prescribed effluent and emissions standard;

\footnotetext{
${ }^{3}$ The Federal Environmental Protection Agency Act is repealed. Repeal of Cap. F 10 LFN, 2004.
} 
the use of monthly discharge monitoring reports; the recognition of environmental auditing; obligations to embrace best practices from other countries whose policy systems have some similarities with Nigeria; introduction of pollution control organizational system and capacity building initiatives to help environmental Pollution Control Managers (PCM) to obtain required competence; and the implementation of stiffer fines, punishment and sentencing (ibid). In

order to encourage compliance by the regulated community, the NESREA compliance Flag Award was established as an incentive-based pollution mechanism performance given to deserving facilities who comply with regulations, guidelines and standards. There are five levels of ratings that range from outstanding to non-compliant using five colour codes. Green flag represent the best performing company.

Table 2.4. NESREA Compliance Flag Award

\begin{tabular}{lcl}
\hline Rating & Level & Range/Colour \\
\hline Above $75 \%$ & 1 & Outstanding - Green \\
$50 \%-75 \%$ & 2 & Good - Blue \\
$35 \%-49.9 \%$ & 3 & Average - Yellow \\
$25 \%-34.9 \%$ & 4 & Poor - Red \\
$155-24.9 \%$ & 5 & Non-compliant - Black
\end{tabular}

Source: National Environmental Regulations (2010) Schedule XIX

According to Ladan (2012), NESREA collaborates with international bodies, Agencies and Non-governmental organisations e.g. UN Agencies; the World Bank; United Kingdom Environment Agency etc. It also shares ideas and disseminates relevant information to key stakeholders including trade unions, professional and business associations, civil society organisations and community based organisations. 
In Ogun State, where data were collected for this research, the following Acts and Regulations are aimed at preventing pollution generally and controlling activities of industrial and commercial activities: the Ogun State Environmental Protection Agency (OGEPA) Act ${ }^{4}$ of 2003 ; Ministry of Environment Law of 2004; the Environmental Protection Miscellaneous Agency Regulation of 2005; and Emission Control Regulation of 2012. The law and regulations in the State are subjected to the NESREA Act 2007 which established the NESREA agency that controls all other environmental agencies in Nigeria.

\subsubsection{International Agreements}

A notable provision of the NESREA Act is section 7(c), which mandates the Agency to enforce compliance with the provisions of international agreements, protocols, conventions and treaties on the environment and such other agreements as may from time to time come into force (Ladan, 2012). Section 12(1) of the 1999 Constitution $^{5}$ provides that, "No treaty between the Federation and any other country shall have the force of law except to the extent to which any such treaty has been enacted into law by the National Assembly'.

The following are some of the major international and regional industrial pollution treaties that Nigeria has ratified or acceded to:

- Basel Convention on the Control of Trans-boundary Movements of Hazardous Wastes and their Disposal;

- Bamako Convention on the Ban of the Import into Africa and the Control of Transboundary Movement of Hazardous Wastes within Africa; and

- Stockholm Convention on Persistent Organic Pollutants (Okorodudu-Fubara, 2012).

\footnotetext{
${ }^{4}$ OGEPA Act 2003 is the principal environmental law in Ogun State, Nigeria. The Ministry of Environment Act 2004 provide for the general management of the environment.

${ }^{5}$ Constitution of the Federal Republic of Nigeria, 1999.
} 
Nigeria has ratified several international agreements on hazardous waste and pollution, but, most of these environmental treaties have not yet been domesticated into law. Hence, for NESREA to enforce compliance with the provisions of such treaties, they must be domesticated and properly 'come into force' (Ladan, 2012).

\subsubsection{Legal Sanctions}

In Nigeria, the following penalties are imposed on any person or corporate bodies in breach of their respective provisions: The NESREA Act Section 20 (3) states that a person who violates the regulations made pursuant to subsection $(1)^{6}$ of this section commits an offence and shall on conviction, be liable to a fine not exceeding N200,000 (1250 CDN) or to imprisonment for a term not exceeding one year or to both such fine and imprisonment and an additional fine of N20,000 (125 CDN) for every day the offence subsists. The Section 20 (4) states that where an offence under subsection (1) of this section is committed by a corporate body, it shall on conviction be liable to a fine not exceeding N2,000,000 (12500 CDN) and, an additional fine of N50,000 (312.5 CDN) for every day the offence subsists. NESREA Act 2007 Section 22 (3) states that a person who violates the regulations made pursuant to sub-section $(1)^{7}$ of this section commits an offence and shall on conviction be liable to a fine not exceeding N50, $000(312.5$ $\mathrm{CDN}$ ) or to imprisonment for a term not exceeding one year or to both such fine and imprisonment and an additional fine of N5, $000(31.25 \mathrm{CDN})$ for every day the offence subsists. Section 4 states where an offence under subsection (3) of this section is committed by a

\footnotetext{
${ }^{6}$ NESREA Act Section 20 (1). The Agency may make regulations setting specifications and standards to protect and enhance the quality of Nigeria's air resources, so as to promote the public health or welfare and the natural development and productive capacity of the nations' human, animal, marine or plant life.

${ }^{7}$ NESREA Act Section 22 (1). The Agency shall, in consultation with appropriate authorities: identify major noise sources, noise criteria and noise control technology; and make regulations on noise, emission, control, abatement, as may be necessary to preserve and maintain public health and welfare.
} 
corporate body, it shall on conviction be liable to a fine not exceeding N500, 000 (3125 CDN) and an additional fine of $\mathrm{N} 10,000(62.5 \mathrm{CDN})$ for every day the offence subsists.

The NESREA Act Section 27 (2) states that a person who violates the provisions of subsection $(1)^{8}$ of this Section, commits an offence and is liable on conviction, to a fine, not exceeding $\mathrm{N} 1,000,000(6250 \mathrm{CDN})$ or to imprisonment for a term not exceeding 5 years. Section 27 (3) states where an offence under subsection (1) of this section is committed by a corporate body, it shall on conviction, be liable to a fine, not exceeding N 1,000,000 (6250 CDN) and an additional fine of $\mathrm{N} 50,000(312.5 \mathrm{CDN})$ for every day the offence subsists.

According to Amokaye (2012), despite environmental statutes imposing penalties on polluters, "there is no known case of judicial prosecution of many polluters since the emergence of FEPA in 1988 until its ultimate demise in 1999. Even its successor, Nigerian Environmental Standards and Regulations Enforcement Agency established in 2007 has no record of enforceability of several regulations - it operates as a toothless bulldog".

\subsubsection{Inadequacies of Nigerian Regulatory Laws}

Governmental intervention to regulate environmental pollution through law, establishment of regulatory agencies and imposition of sanctions to deter polluters may to a certain extent enhance social welfare. According to Esty (1999), many regulatory frameworks fail because governments lack necessary information/data and incentive structures needed to regulate environmental pollution efficiently. Structural failures might arise in industrial pollution regulations as a result of government policy decisions that exclude those who are either causing

\footnotetext{
${ }^{8}$ NESREA Act Section 27 (1). The discharge in such harmful quantities of any hazardous substance into the air or upon the land and the waters of Nigeria or at the adjoining shorelines is prohibited, except where such discharge is permitted or authorized under any law in force in Nigeria.
} 
or suffering harm. Also, Esty (1999) argued that regulatory efforts may be distorted by corrupt decision makers; and through the influence of special interest groups whose actions are not true reflections of the will of the people.

Amokaye (2012) stated that inadequacies in the Nigerian environmental regulatory framework could be as a result of three factors: information shortcomings; administrative shortcomings; and a misallocation of environmental responsibility. One of the problems in policy formulation and implementation in many developing countries, such as Nigeria, is the absence of reliable data and information to guide policymakers in decision-making. Hence, environmental regulation cannot be effective when data are inadequate, unreliable and inconsistent. How do regulatory authorities know when a polluter has exceeded its permit when there is a lack of appropriate technologies to measure the level of its emission? According to the United Nations Industrial Development Organization (UNIDO) independent country evaluation of Nigeria, conducted in 2011, the country lacked comprehensive and organized data on industrial environmental pollution, a necessity for monitoring and enforcing compliance. Using Lagos, the industrial city of the nation as a proxy for its evaluation, the result showed that effluents beyond the allowable limits were freely disposed in public waterways and land, and contaminated with toxic chemicals at levels higher than what can be considered as safe for the society and the environment. The evaluation report also showed that despite the directive given by the Lagos State Environmental Protection Agency (LASEPA) for the implementation of pollution abatement equipment, only $25 \%$ of the industries in the State had complied (ibid).

The second shortcoming relates to administrative capacity. Regulatory bodies may operate inefficiently due to lack of cooperation with one another, and this can create jurisdictional problems. Even where they act, they may under-regulate or condone polluting 
activities rather than perform their assignments with full diligence (Amokaye 2012, 36). It is worth mentioning that under-regulation is well pronounced in Nigeria.

The third challenge is the misallocation of environmental responsibilities: there is no clear division for environmental management between the three tiers of government in Nigeria; rather the provision of Section 20 of the 1999 Constitution states that environmental protection is a joint responsibility of the Federal, State and Local government. This has led various stakeholders to ask which level of government has the responsibility to regulate industrial pollution within the constitutional framework of Nigeria.

\subsection{Industry and Sustainable Development}

The Agenda 21 and the Rio Declaration on Environment and Development provided the necessary framework for policy discussion on matters related to industry and sustainable development (SD). One of the core tenets of the convention was that attitudes and behaviour regarding development had to change in order to stop the destruction of the planet's natural resources. In order to achieve the objectives of $\mathrm{SD}$, governments were enjoined to integrate economic, social and environmental concerns in their policy-making; that is, governments needed to maximize the positive influence of industrial activities on economic and social development, while minimizing the negative impact of production and consumption on the environment. The United Nations World Commission on Environment and Development (WCED) defines SD as "development that meets the needs of the present without compromising the ability of future generations to meet their own needs" (Brundtland Commission, 1987). Achieving environmental sustainability requires managing and protecting ecosystems to maintain both their economic productivity and their ecological functions, maintaining the diversity of life in both human-managed and natural systems, and protecting the environment 
from pollution to maintain the quality of land, air and water (Canadian International Development Agency (CIDA), 1992).

Industries play a major role in the development process of any region, particularly in developing countries. Sustained efforts are required to maintain the pace of development if the country has to survive in the changing global context (Goyal, et al. 2008). Research conducted on a sample of sixty manufacturing industries in Nigeria by Ngwake (2008) showed that most of the 'environmentally responsible' industries had established a culture of being environmentally conscious even before environmental regulations were developed for the sector, the main reason was to meet the global sustainable production and consumption standards for industries. Agumwanba (1998) argued that inequality is manifested in the social, economic and political situation in Nigeria. There is poor distribution of wealth that creates a wide gap between the rich and the poor in the society as a result of corruption and abuse of political power. This situation has given rise to individuals who are above the law - they manipulate laws and regulations to their advantage (NEEDS, 2004). Also, Agumwanba (1998) stated that as a result of political interest, industry owners carry out activities and flout regulations meant to protect the environment, and regulators are bought over through monetary inducements. Oyelakin-Oyelarin (1997) in his study of industrial clusters of Nnewi Nigeria twenty years ago asserted that clustering created environmental problems because of heavy presence of industrial polluters, and subsequently made the attainment of environmental sustainability difficult.

In this study, the efforts of the officials of the State Ministry of Environment, and the perceptions of the local residents about the state of the environment will give an insight on whether the governments have been able to work towards achieving a healthy environment for the Ota community residents in accordance with the global best practices. 
Pollution from industries often negatively impact neighbouring communities; and the areas in close proximity to industrial activities are often marked by noticeable contamination of air, soil, and water that can ultimately lead to illness and/or harm to the residents in the affected areas. From the review of literatures, chemical and petrochemical industries have been identified as large emitters of not only metals but also a wide variety of pollutants; also it is obvious that industrial pollution is noticeable mostly in industrial cities in Nigeria, in which Ota, Ogun State is one of them. 


\section{Chapter 3: Methodology}

\subsection{Study Area and Motivation}

The area of study is Ota in Ogun State, Nigeria. It is the headquarters of the Ado-Odo/Ota Local Government Area whose population has grown from 14,248 in 1963 to an estimated 142,793 by 2003 (CPMS 2005a). It is situated on latitude $6^{\circ} 32 / \mathrm{N}$, longitude $2^{\circ} 57 / \mathrm{E}$. Lagos which has grown from a set of farming and fishing villages to arguably the third largest city in the world is estimated to have a population of 13million persons (UNDESA, 2011). This continual growth and development has extended to suburban areas as well as on the frontier settlements of Ogun State (Kadiri, 2001). One of such frontier settlements is Ota Township in Ogun State which is situated near the boundary of Lagos State and has steadily grown as a result of its proximity to Lagos (Kadiri, 1992). Ogun State Government of Nigeria (2008) also identified Ota as one of the neighbouring settlements to the Lagos Metropolis bearing the brunt of the expansion pressure of the Lagos Metropolis. In real distance, Ota is about $53 \mathrm{~km}$ to Abeokuta - the Ogun State capital, and 22km to Ikeja - the Lagos State capital. Farming and trading are the dominant occupations, and this is similar to the occupations of about $52 \%$ of the Nigerian population who are living in rural and semi urban communities (Olusimbo et al, 2010).

Ogun state is one of the industrialized states in the southwest Nigeria with Ota as its largest industrial city. Balogun (2014) in the News Magazine titled "Ogun State: Nigeria's New Industrial Hub" reported that not less than 50 major manufacturing firms were attracted to Ogun State since 2011 as a result of availability and ease of acquisition of land for investment purposes. Also, it was reported that the state offers 70 per cent rebate on cost of land, making the 
documentation of such properties easy and prompt by the removal of the hitherto administrative barriers.

Ota Industrial Estate was established by the Ogun state government in 1983 to attract manufacturing industries from the older and choked Ikeja industrial estate of Lagos, and also provide additional revenue sources to the state to facilitate rapid development of the Ota area (Odesanya et al, 2012).

Salau et al (2013) asserted that commercial activities in Ota take place in a linear form along the major arteries of Lagos - Abeokuta Expressway, Ota - Ijoko Road and Ota - Idiroko Road. Two factors motivated the selection of Ota for this study: (i) the large presence of industries in the area and being a backbone of Ogun State economy; (ii) the opportunity to survey the neighboring residents' perception of industrial pollution to guide the development of applicable and appropriate policy options. The maps in Figure 3.1 below shows Nigeria which contain Ogun State and Ota, the study area. 


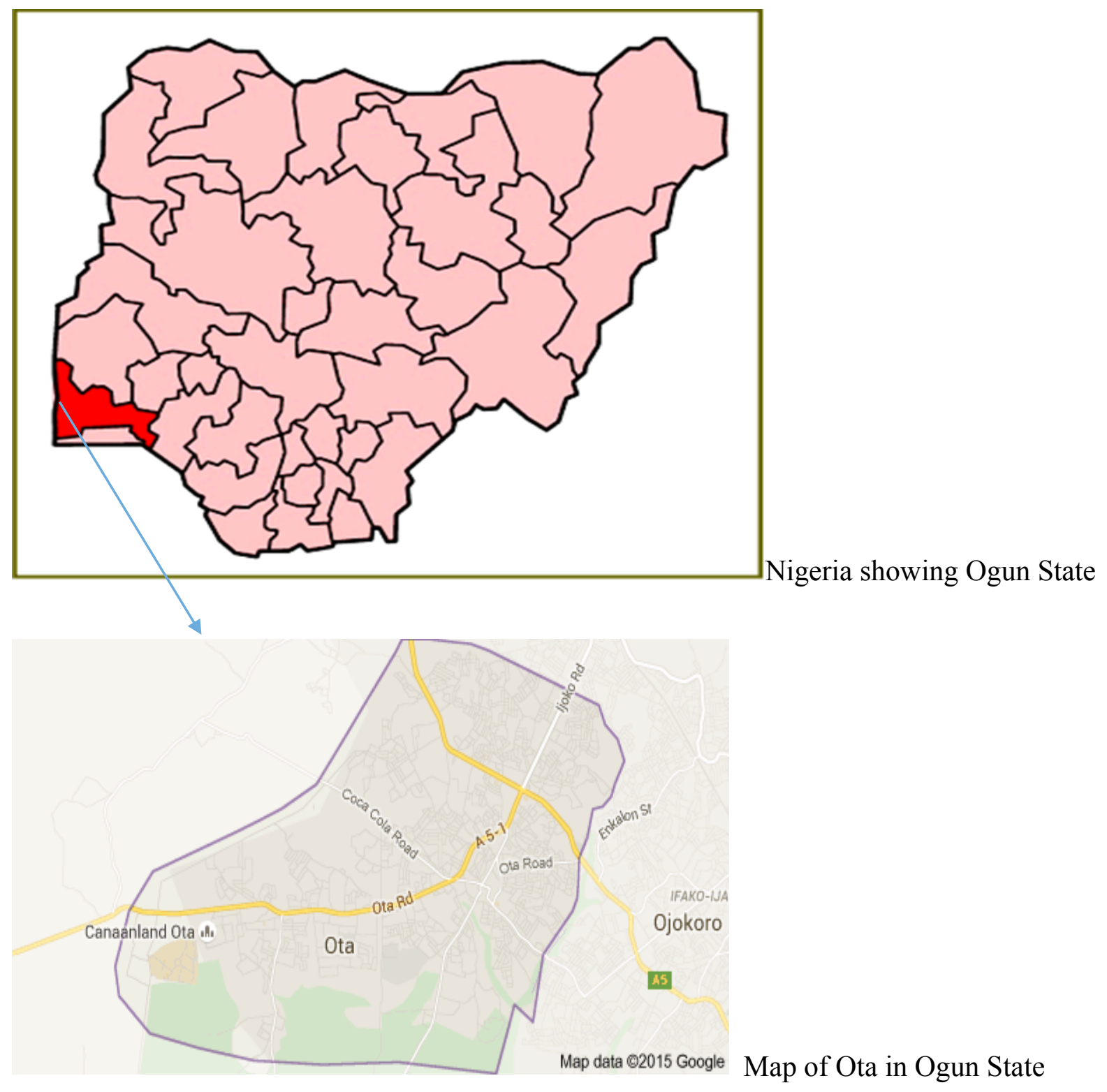

Figure 3.1 Map of Area of Study

\subsection{Research Methods}

This study uses a multi-method approach that includes qualitative and quantitative methods to determine the perceptions of community members on industrial pollution and the policy actions of government. According to Sommer \& Sommer (2002), a multi-method approach offers greater flexibility than a single method can provide. Combining several methods 
can fill gaps and can often bring to light diverse aspects of the subject that may be missed when only one method is used. The authors also stated that this approach increases the validity of the findings and the understanding of the phenomena being examined since individual methods can be compared and results can be verified from different angles. The research proposal was submitted to the University Research Ethics Board; the protocol was approved on July 12, 2014, and the survey was conducted in August 2014. The key multi-methods used include a household survey, a questionnaire and interviews with key stakeholders. Primary and secondary sources were also collected.

\subsubsection{Sampling Technique}

The sampling technique that I used is judgmental or purposive sampling. This technique is a type of non-probability sampling in which the researcher chooses the sample based upon a variety of criteria which may include specialist knowledge of the research issue, or capacity and willingness to participate in the research. It is used when the interest of the research is on a specific field or a small group (Steinke, 2004). There is no cap on how many informants should make up a purposive sample, as long as the needed information is obtained (Bernard 2002). This method is especially useful when there is not enough funds and other resources (Topp et al. 2004). Both qualitative and quantitative sampling methods may be used when samples are chosen purposively, such as participant-observation studies (Walker et al. 2004), questionnaires (Zhen et al. 2006), direct observations (Martinez-Romero et al. 2004) and interviews (Anderson 2004, Li et al. 2006). This sampling method is not free from bias, but it can provide reliable and robust data. The strength of the method actually lies in its intentional bias (Bernard 2002, Lewis \& Sheppard 2006). 
Ota consist of four areas: Ota Township (the traditional core area); Sango; Industrial Housing Estate and Onipanu/Iju (newly developing industrial areas). I purposely chose the above mentioned areas for sampling because they represent the locations where the industries in Ota are situated. I assigned a number to the first one hundred housing units that were located a distance of $100 \mathrm{~m}$ to $500 \mathrm{~m}$ from the nearest industries. I assigned each a number from 1 to 100 . Then I randomly selected 25 numbers. The sampling was done manually whereby 100 pieces of paper were put in a bowl and mixed up properly; then a number was selected one at a time until 25 numbers were purposely selected. Within each area, I purposely chose 25 households or housing units where questionnaires were administered.

\subsubsection{Data Collection Methods}

This study used two data collection techniques: primary and the secondary sources. The primary consisted of a questionnaire through which quantitative data were gathered, and semistructured interviews used for qualitative data collection. Questionnaires and interviews are a widely used social research method for collecting data from and about people.

\section{Questionnaires}

Questionnaires "are made up of a series of written questions on a topic" and are used for "systematic gathering of information about people's beliefs, attitudes, values, and behaviour" (Sommer \& Sommer, 2002: 136). The benefit of questionnaires is that they are generally efficient in terms of time and effort for both the researcher and the respondents (Sommer \& Sommer, 2002).

In this study, questionnaires that contained open and closed ended questions were used to collect data to determine the perceptions of community residents to industrial pollution. Closed- 
ended questions were multiple choice and ranked questions. Ranked questions asked respondents to identify the level of importance a particular factor had in reference to the question asked. Open ended questions allowed respondents to provide their own answers in their own words. The questionnaire is divided into three major sections: demographic factors, industrial pollutants, community environmental relationship/corporate social responsibility. Only respondents of eighteen years of age and above, either male or female, were instructed to complete the questionnaire. On every occasion, the researcher explained the rationale behind the project and its benefits to the communities. Also, during the study, the researcher assisted eight respondents who were illiterate to administer their questionnaires after having discussions with them in local language. To gather additional information on salient issues that are not included in the questionnaire, the researcher took handwritten notes of the participants' responses. The limitation of this type of interview is: writing notes at the time of the interview can interfere with the process, and notes written afterwards are likely to miss out some details.

One hundred questionnaires were distributed to all the hundred households purposely selected for the survey (that is, one questionnaire per each household). In some cases where multiple people were at home, the oldest adult persons were asked to fill out the questionnaire. Eighty-Seven questionnaires were completed, and thirteen questionnaires were not returned or uncompleted. A sample of the household questionnaire is provided in Appendix 7.

\section{Semi-structured interview}

Britten (1995) stated that interviewing is a well-established research technique in social sciences field study. There are three main types: structured, semi structured, and in depth interviews. Structured interviews consist of administering structured questionnaires, and the interviewers ask questions (mostly fixed choice) in a standardised manner. Sommer and Sommer 
(2002) warn that the further the researcher moves from a structured procedure, the greater the risk of interviewer bias. Semi structured interviews are conducted on the basis of a loose structure consisting of open ended questions that define the area to be explored, at the initial stage, and from which the interviewer or interviewee may deviate for a more detailed idea. In depth interviews are less structured than this, and may cover only one or two issues, but in much greater detail.

The interviews for this study were semi-structured and questions were open-ended. The semi structured process allows the interviewer to ask the same questions to all respondents, but with the ability to change the order in which the questions were asked, as well as the manner and wording (Sommer and Sommer, 2002). A total of ten industry representatives and eight officials in the Inspection, Monitoring and Compliance Department (IMCD) of the Ministry of Environment were interviewed. Recruitment letters were sent to the industries and Ministry of Environment (see Appendices 2 and 3) to seek their consent to participate in the research. A recruitment script used in community resident recruitment is provided in Appendix 1.

Ten manufacturing firms of various sizes, and from different sectors and different years of existence (Table 4.4., p.71) were purposely selected in Ota based on the discretion of the researcher, and willingness of the firms' representatives to participate in the research. Openended questionnaires, which contained thirteen questions, were used to collect data from the chosen companies. Issues addressed in the questionnaires included: number of employees, sector/primary production, age of companies, environmental concerns/pollution, environmental policy initiatives and corporate social responsibilities.

In the Ogun State Ministry of Environment Abeokuta Nigeria, open-ended questionnaires were given to eight government officials, of which six questionnaires were completed and 
returned to the researcher. Also in-person interview was conducted with the Commissioner for Environment with a tape recorder for almost one hour, and the interview was transcribed. The interview guide for the industry representatives and the Ministry of Environment officials are presented in Appendices 8 and 9. Also, other general observations were recorded during the study as a result of watching and listening.

Secondary data sources complemented the primary data to get a wider perspective. This was done by obtaining additional data from academic literature, documents of the NESREA and Ogun State Ministry of Environment.

During the research process, confidentiality of data was maintained. Ryerson University stipulates that all research involving human subjects in data gathering must be approved by the University's Ethics Board, and that all involved participants agree to sign the consent form. The protocol approval policies were strictly adhered to. The provided Consent Agreement forms are

located in Appendices 4, 5 and 6. Also, given that this study is conducted with community people, industrial employees and government officials, specific names of persons and survey responses were kept confidential. Collected information was stored on encrypted files.

\subsection{Limitations of the Study}

Considerable efforts were expended to acquire data from the Ministry of Environment, but the lack of data on industrial pollution affected the study. Although, the administration of structured questionnaires is an acceptable conventional method of field study for data collection, its use was limited for two major reasons: (i) time and cost affect the administration of many questionnaires; and (ii) attempts made to administer questionnaires met with some apathy from the local residents and industry representatives. Some local residents claimed the government 
had never come to their aid despite complaints. The industry employees were afraid of punishment if they divulge proprietary information to the interviewers.

Surveys and interviews rely on voluntary information; they are therefore subject to many sources of error. People deliberately distort the truth, inadvertently fail to recall events correctly, or refuse to participate. This investigation is also prone to mistakes, and it might not be completely free of errors as well. The purposive sampling technique used in this study is prone to bias and the results cannot be used to make general conclusions because the sample is not representative of the population.

\subsection{Statistical Analysis}

The quantitative data was analyzed using Microsoft Excel, a simple descriptive statistical method to generate the graphic illustrations. This is considered the appropriate analytical technique for the study objectives.

Content analysis was used to analyze the qualitative data. Content analysis is "a procedure for the categorisation of verbal, print, or electronic text data obtained from narrative responses, open-ended survey questions, interviews, focus groups, observations, or print media such as articles, books, or manuals" (Kondracki \&Wellman, 2002) for purposes of classification, summarisation and tabulation. It involves coding and classifying data, with the aim to make sense of the data collected and to highlight the important messages, features or findings. Content analysis according to Onwuegbuzie (2009) includes creating smaller chunks of data and then

placing a code with each chunk, and subsequently place the codes into similar groupings and counted. In this study, the content is analysed on basic level: this involves a descriptive account 
of the data i.e. this is what was said during the interview, but no comments or theories as to why or how. 


\section{Chapter 4: Research Findings}

The results of this study were derived from the analysis of both survey and interview data. The research findings are presented under three broad categories - the community residents, industry representatives, and government officials.

The findings show that air pollution is the major environmental problem in Ota communities; the residents thought the companies are not doing enough to mitigate pollution and to support the communities. Also, community residents do not have confidence in government pollution management.

\subsection{Community Residents}

The area of study - Ota, is the headquarters of the Ado-Odo/Ota Local Government Area of Ogun State Nigeria with an estimated population of 142,793 by 2003 (CPMS 2005a). Ota is situated near the boundary of Lagos State and has steadily grown as a result of its proximity to Lagos (Kadiri, 1992). Salau et al (2013) stated that the average household size in Ota is quite large, and it is between 5 and 9 persons. The proximity of residential houses to industrial facilities in Ota, make residents vulnerable to industrial pollution and health hazards (Etim, 2012). The photos in Figures 4.1 and 4.2 below depict the proximity of some residential buildings to companies in Ota communities. 
Figure 4.1 Households close to a factory in Ota Industrial Housing Estate

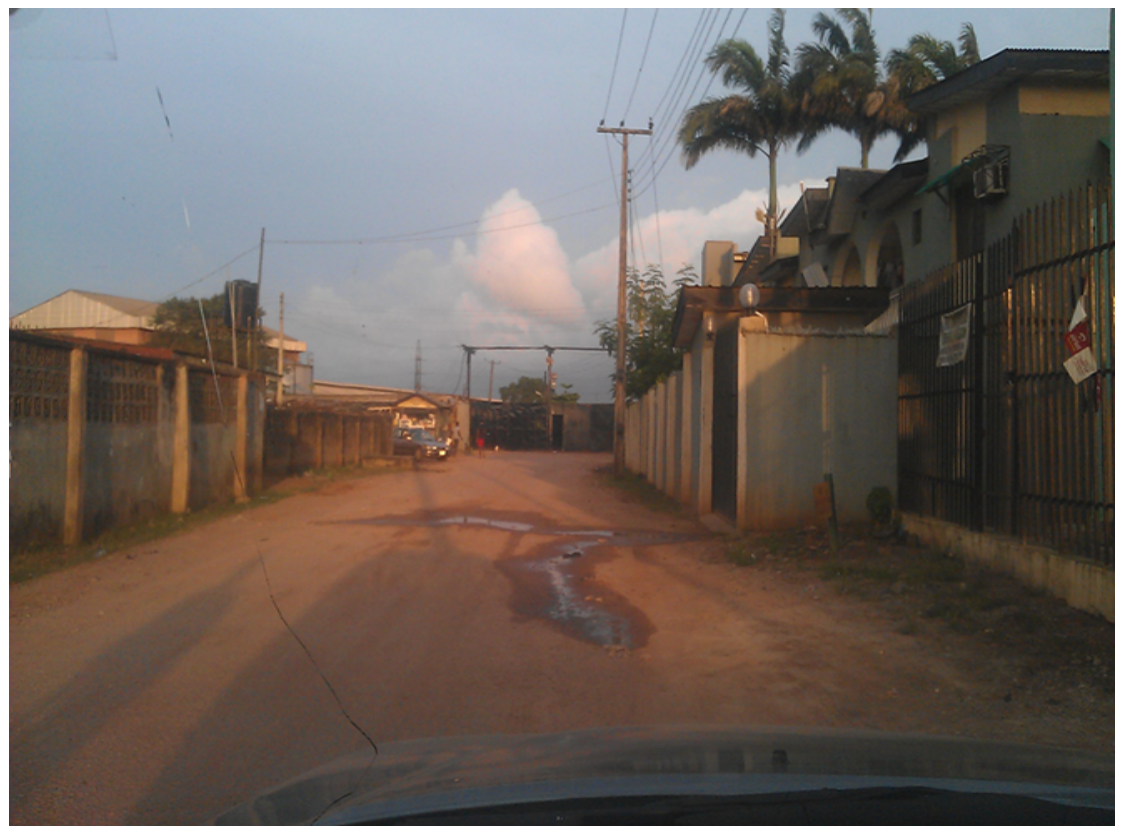

Figure 4.2 Households close to a factory in Ota Township

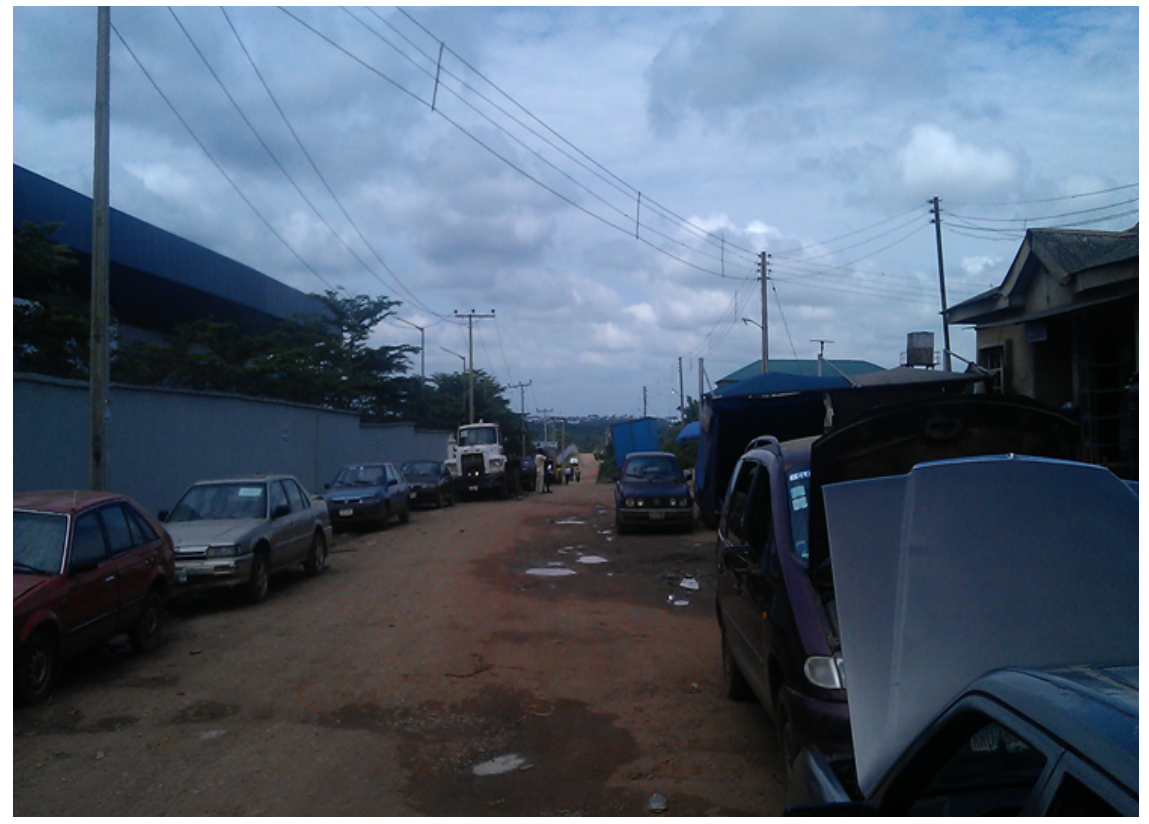


In this study, information on sex, age, education level and occupation were collected from respondents. Figure 4.3 shows the distribution of survey respondents by sex.

\section{Figure 4.3 - Sex distribution}

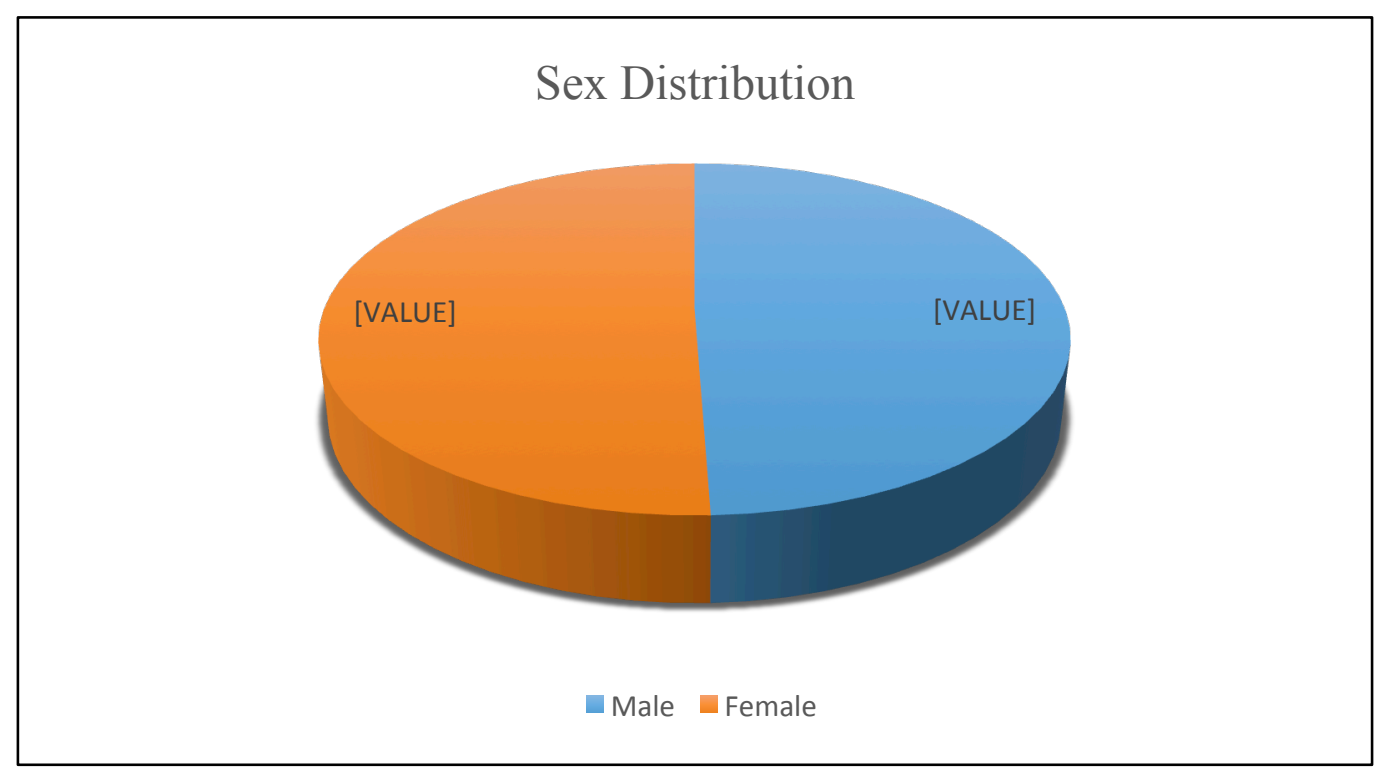

Forty-four survey respondents were female while forty-three were male. The sex distribution is balanced because there is almost an equal amount of male and female participants.

Figure 4.4 - Age distribution

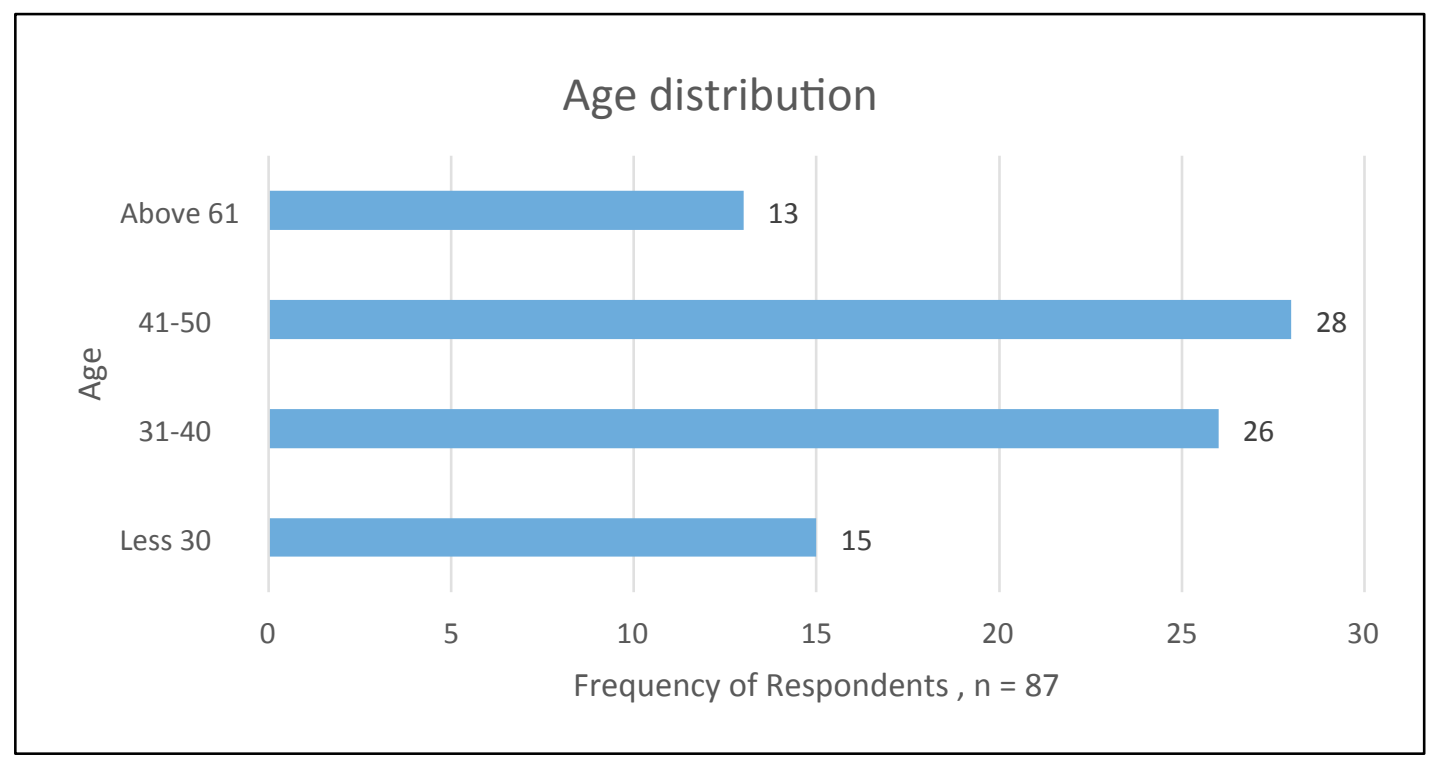


The analysis of respondents in terms of age shows that twenty-eight respondents fall in the category of 41-50 years. Twenty-six respondents from the sample are in the category of 3140 years. The frequency of the respondents who are in the category of less 30 years is fifteen while the frequency of respondents that is above 51 years is thirteen. The age categories of $31-40$ and 41-50, consisting of fifty-four respondents out of the total number of respondents, constitute the majority of the residents that were sampled for the research.

\section{Figure 4.5 - Occupational distribution}

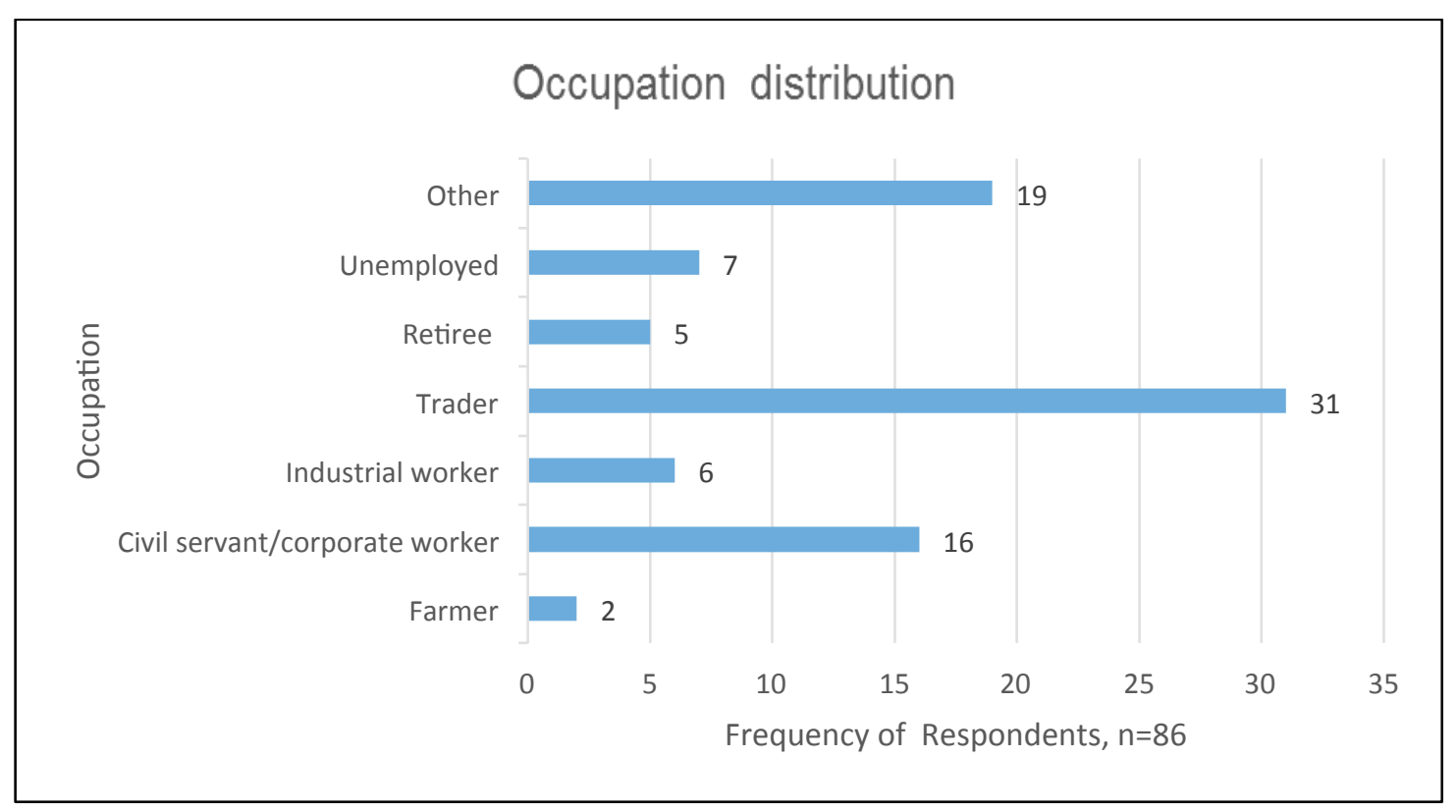

Findings from occupational distribution in Figure 4.5 shows that thirty-one respondents were traders while nineteen study participants represent other type of occupations such as students. Sixteen respondents have a job in both the private sector and government. Seven people from the total sample are unemployed, six respondents are industrial workers while five interviewees are retirees. Only two respondents were engaged in farming as their occupations.

Ota communities have a relatively high employment rate as only seven respondents out of eighty-six respondents sampled were unemployed persons. Only a few respondents were 
students. Further breakdown of the employment status showed that informal sector employees were mainly artisans and shopkeepers, while those employed in the formal sector were civil servants, corporate workers and industrial workers. The self-employed respondents were mainly engaged in farming and trading. Friedrich (2002) argued that informal sector makes up a significant portion of the economies in developing countries; workers in this sector earn less income and have no access to basic protections and services (Lourdes and Floro, 2006). These features differ from businesses and employees in the formal sector which have regular hours of operation, a regular location and benefits (Meier \& Rauch, 2005).

\section{Figure 4.6 - Distribution of educational qualification}

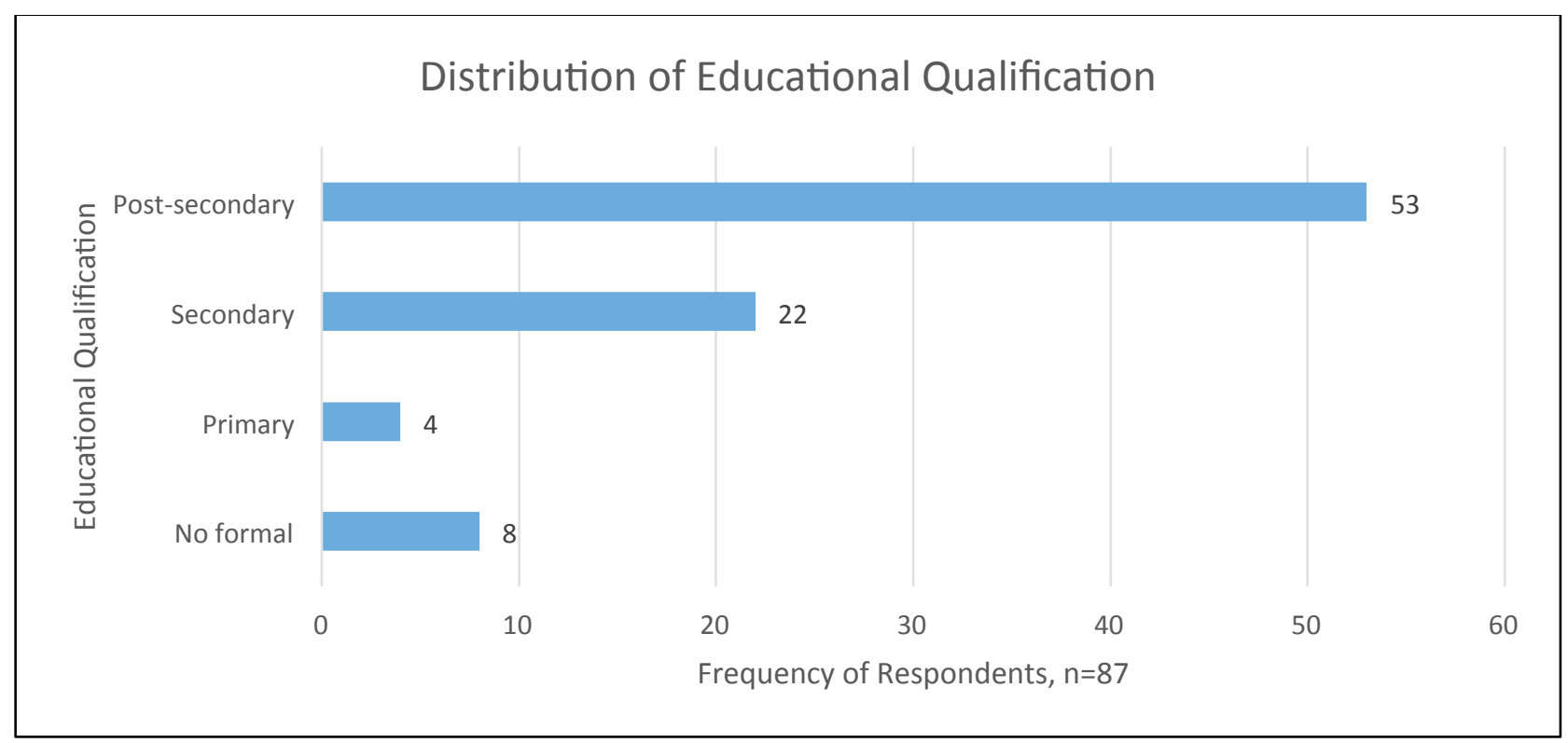

The study population is quite literate and educated, as fifty-three respondents have completed tertiary education, while twenty-two respondents have completed secondary school education respectively. It is observed in the study that eight respondents are illiterate with no formal education while a lower proportion of four respondents in the sample have primary education. The high proportion of literate population may be attributed to the concentration of 
factories in Ota requiring skilled manpower. These results validate the findings of Salau et al (2013) that Ota is literate by UNESCO standards.

Figure 4.7 show the residential location of respondents. This graph shows that twenty-five Ota township residents, nineteen Ogun State Housing Estate residents, twenty residents of Sango Ota, and twenty-three residents of Onipanu Ota completed the questionnaires. The result reveals a good distribution of respondents' residential location to industries in the study area.

\section{Figure 4.7 - Residential location of respondents}

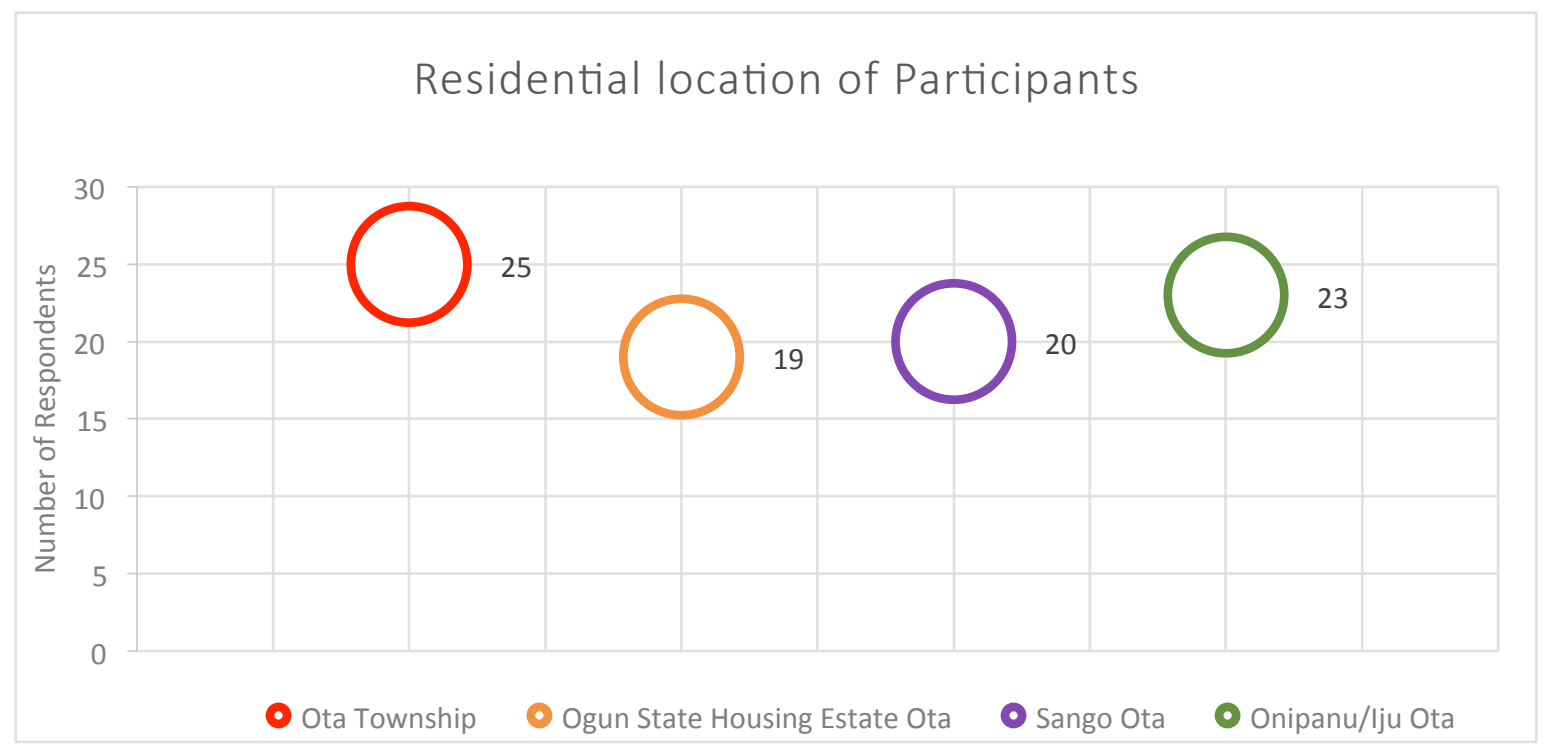

Figure 4.8 - Residential status of participants

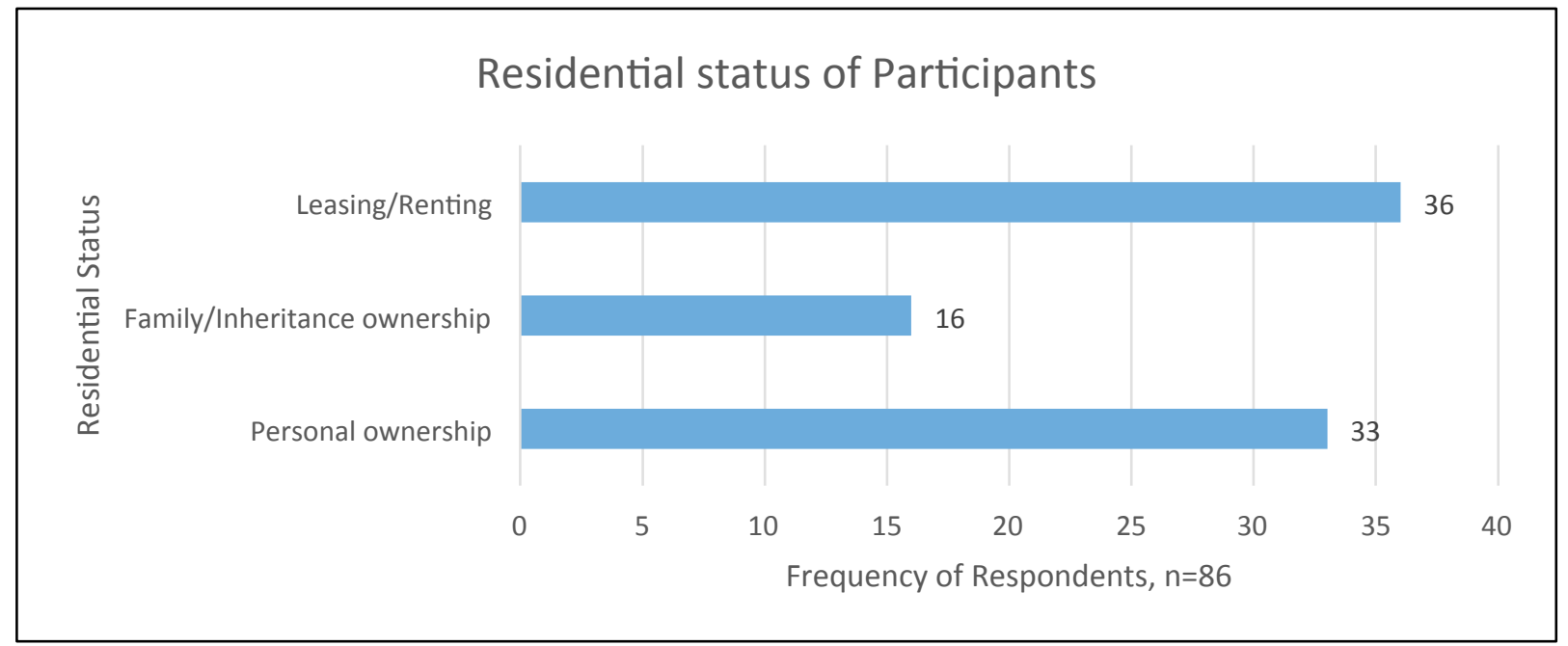


The residential status in the study area is such that majority of respondents were owner occupied: thirty-three interviewees said they were personal owners of their houses; while sixteen respondents got ownership through family/inheritance status. Also, thirty-six respondents were tenants, and this proportion might be due to the high concentration of the public and company workers who are residents in the study area.

\section{Figure 4.9 - Length of residence in the community}

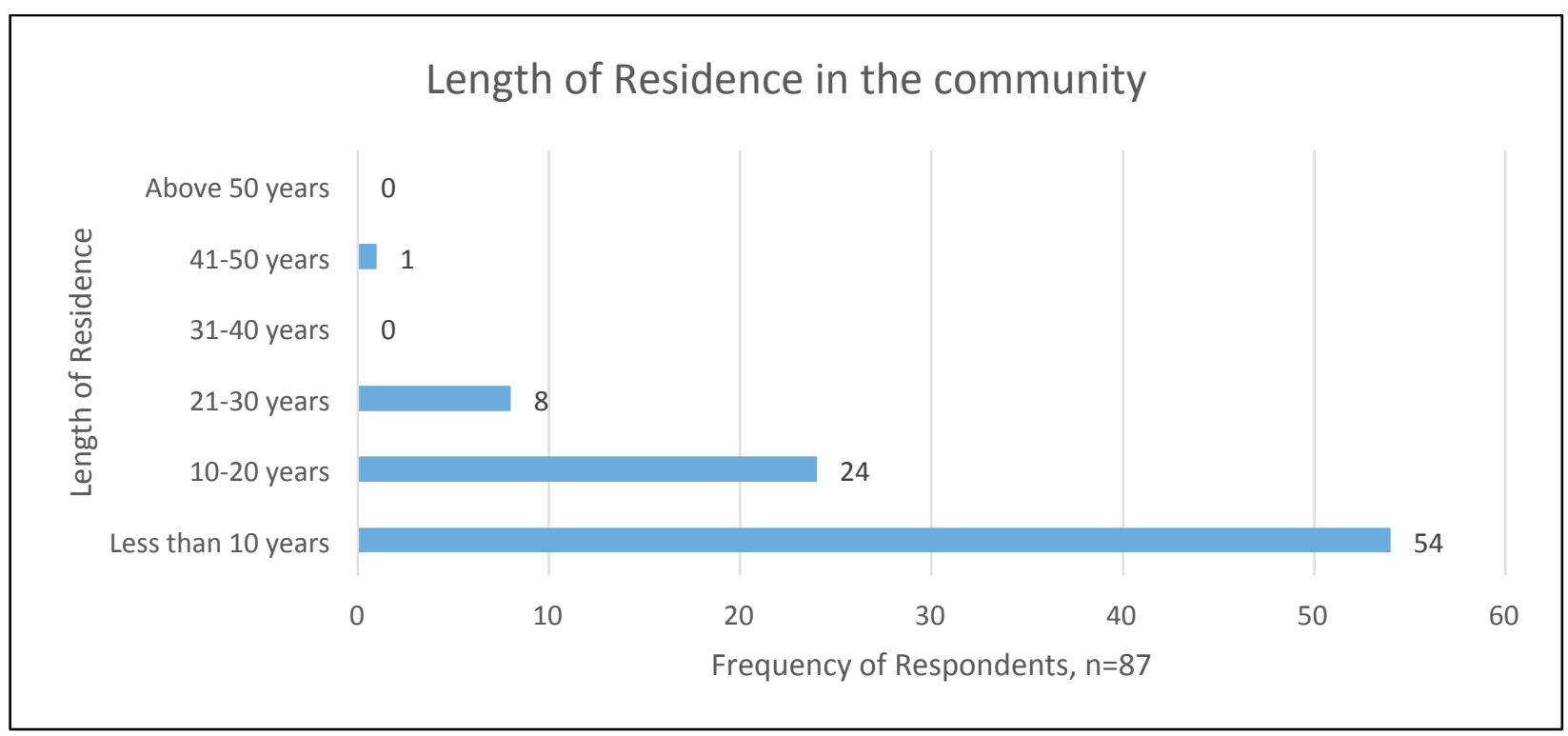

Fifty-four respondents, which constitute the majority, had lived in Ota for less than 10 years while twenty-four respondents have been living in the community for 10-20 years. The reasons why many people moved to Ota within a period of twenty years could be as a result of influx of industries from Lagos and creation of employment opportunities. Eight respondents fall in the category of 21-30 years whereas one respondent is in the category of 41-50 years. None of the participants interviewed have stayed in Ota communities for a period of 31-40 years and above 50 years respectively. 
Figure 4.10 - Distance of residence to the nearest industry

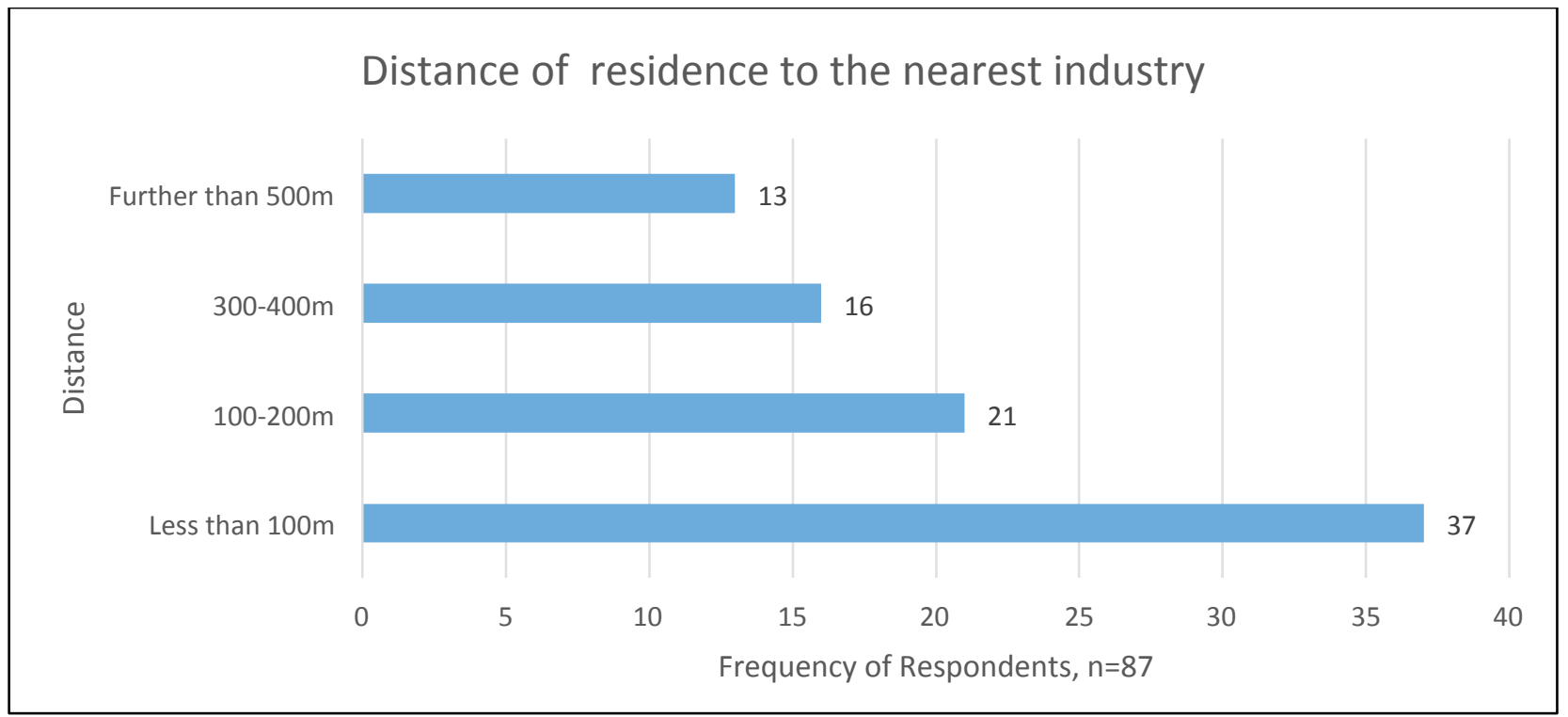

From investigations conducted, thirty-seven of the total respondents lived less than $100 \mathrm{~m}$ away from the nearest industry, twenty-one of the respondents lived 100-200m away from the industry, sixteen of the respondents lived 300-400m away from the factory, while thirteen of the respondents lived $500 \mathrm{~m}$ away from the industry. From the analysis, the majority of the respondents (58) lived within less than 100 to $200 \mathrm{~m}$ away from the nearest industry; this means they are all under the influence of pollution resulting from the operation of the industry and permits an evaluation of the perception of exposure to pollution, which has been previously shown to be high amongst communities close to industry (De Bartolomeo et al; Landajo et al; Mir et al 2004). 
Figure 4.11 - Size of industry close to residence

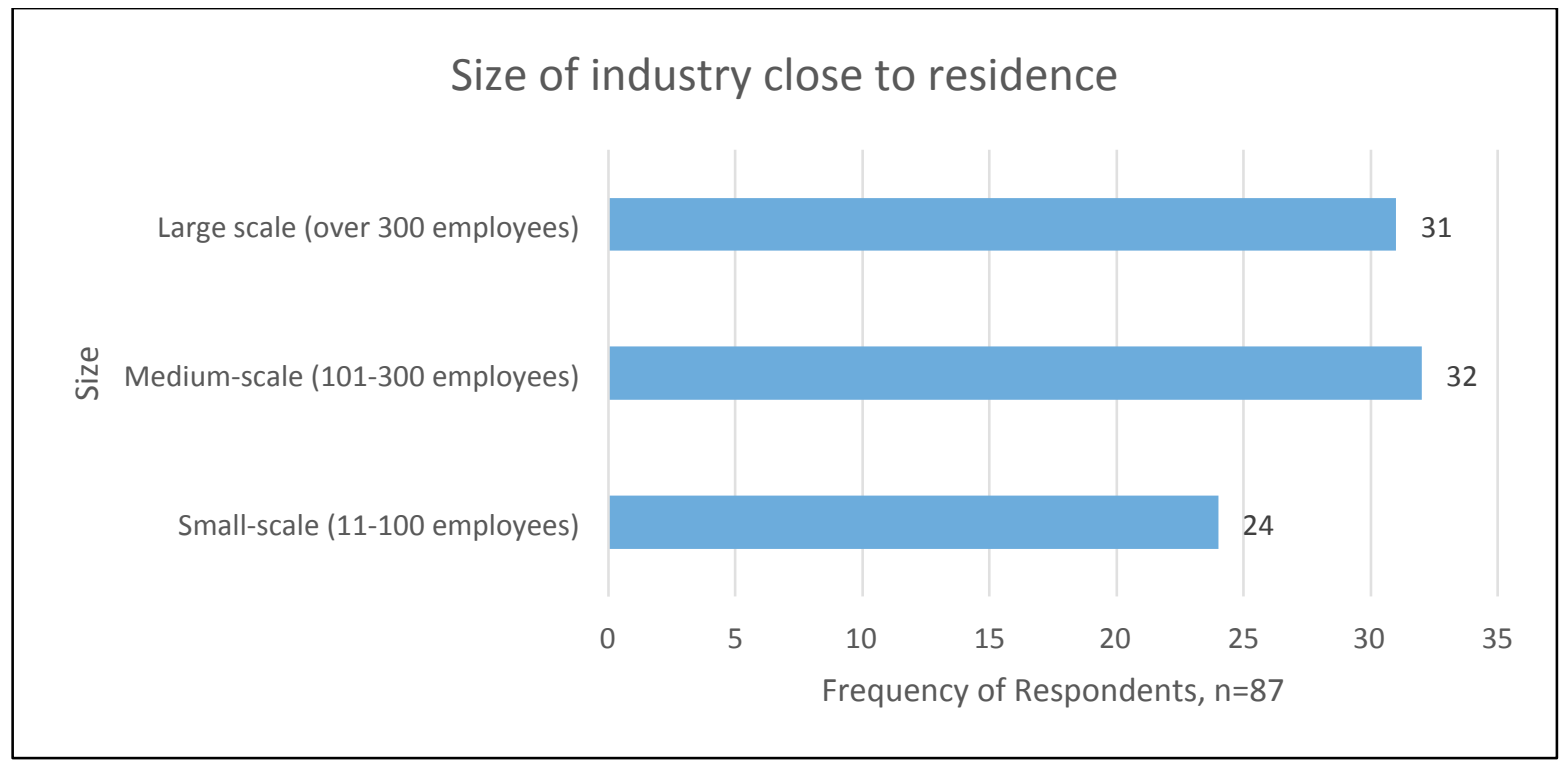

Most of the manufacturing industries operating in Ota communities are -medium and large scale firms. Details of the labour force in the study area revealed that thirty-two of the respondents said that industries close to their homes had a labour force of $101-300$, thirty-one of the respondents said that the size of the industry close to their residents had over 300 employees and 24 respondents thought the industries close to them had a workforce of $11-100$ employees.

\section{Figure 4.12 - Type of industry}

\section{Type of Industry}

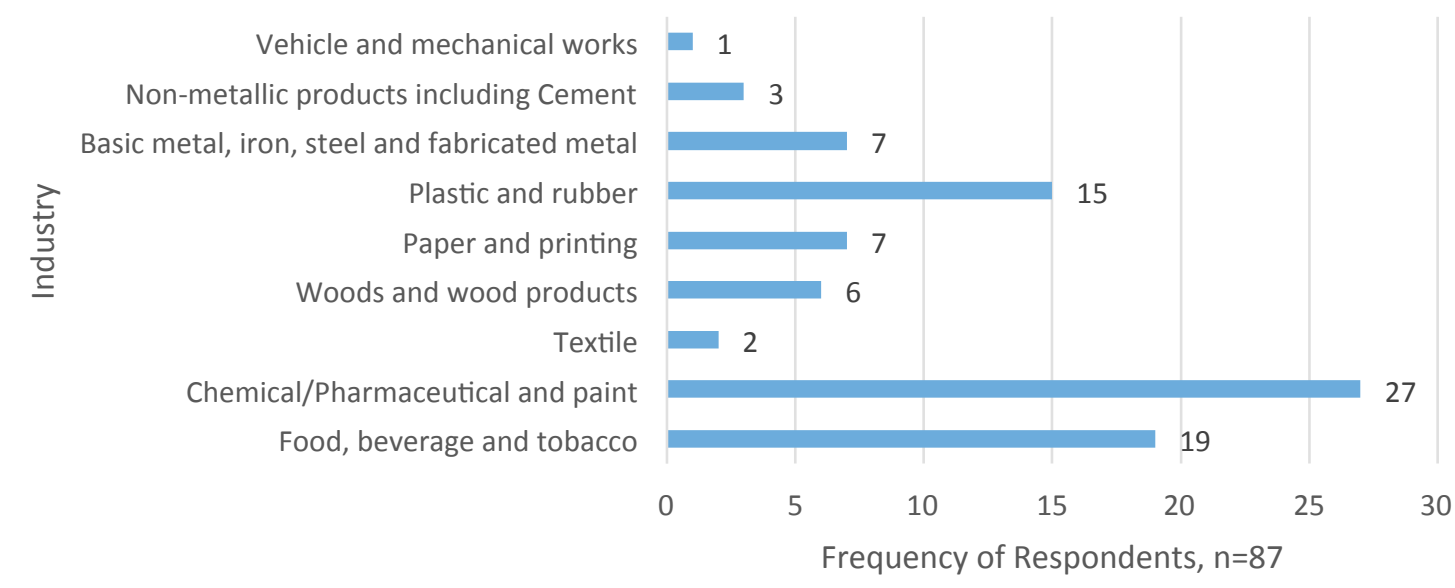


Another important consideration was the type of industries that were close to households. Twenty-seven respondents replied that chemical, pharmaceutical and paint industries were the nearest type of industry to their residential buildings. Nineteen respondents answered that the nearest industry type to their residences are food, beverage and tobacco. Fifteen respondents said they are neighbours to plastic and rubber industries. Basic metal, iron, steel, and fabricated metal, paper and printing industries were close to seven respondents. Six respondents replied that wood and wood products industries are close to their homes. Three respondents said their residences are close to non-metallic products companies; two respondents replied that their homes are in the vicinity of textile industries; and one respondent answered that vehicle and mechanical work industry is the type of industry close to his house.

Odesanya et al. (2012), in the research conducted with the use of Industrial Pollution Projection System (IPPS), estimated the pollution load in Ota and Agbara Industrial Estates of Ogun State Nigeria. The authors stated that the most polluting sectors are chemical and pharmaceuticals $(\mathrm{CPH})$ and food, beverage and tobacco (FBT). The least polluting sectors are electrical and electronic sector (EES), Motor vehicle assembly (MVA) and Wood and wood products (WWP). Also, this statement corroborates with Nadal et al, (2009) that chemical and petrochemical industries are large emitters of metals and a wide variety of pollutants e.g. VOCs, PAHs, and PCBs.

\section{1. 1 Perception of Respondents to Industrial Problems in Ota}

The study investigated the reaction of the inhabitants to the problems of industrial location as it affects their stay in their neighbourhood. Variables such as noise, dust, offensive odour, smoke, fumes, and health hazard were identified. Several questions were asked relating to 
the household perception of industries. Table 4.1 reveals how many respondents thought the industries nearby pollute.

Table 4.1 Do you think industries near you pollute the environment?

\begin{tabular}{|l|l|}
\hline Response & Frequency \\
\hline Yes a lot & 42 \\
\hline Yes a little & 31 \\
\hline No, not very much & 13 \\
\hline Total & 86 \\
\hline
\end{tabular}

The question was asked if the nearby industries to the residential buildings pollute the environment. A majority of the respondents, forty-two, replied "Yes a lot" that the industries pollute the environment. Also, thirty-one respondents answered "Yes a little" that the industries pollute the environment, but the rate of pollution is minute. Thirteen respondents replied "No" that the industrial environmental pollution was not much. It is therefore evident from this analysis that a majority ( $85 \%$ - yes a lot and yes a little) perceive pollution to exist in Ota communities, but the rate of pollution depend on the nearness of these industries to residential houses. The study was also interested to know how people learned about the potential concern with industrial pollution and their level of concern. Figure 4.13 shows how people learned about pollution. 
Figure 4.13 - Media through which industrial pollution is heard

\section{Media through which citizens heard about industrial pollution}

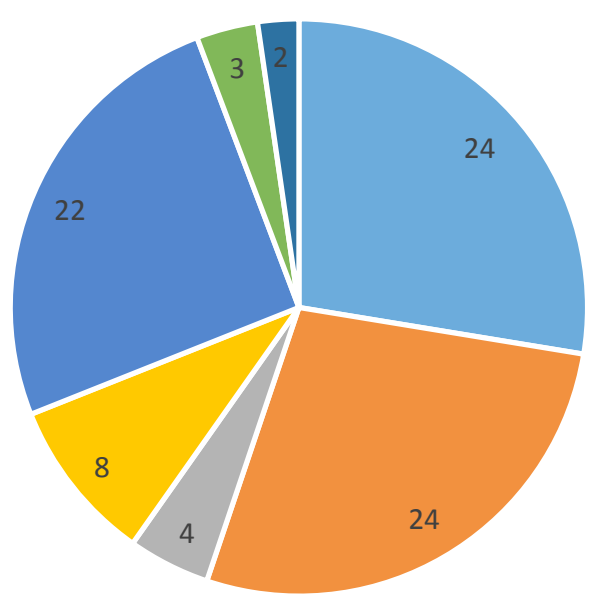

- Radio

- Television

- Internet

- Newspaper

- People

- None

- No response

The result of the analysis shows that twenty-four respondents heard about industrial pollution through radio and television media. Twenty-two respondents said that they heard about industrial pollution through word of mouth or from other people, while eight respondents replied that they heard about pollution through newspapers. Four respondents learned about industrial pollution from the Internet, and three respondents answered that they had not heard about pollution through people, electronic or print. It can be inferred from the findings that the main media through which the residents hear about industrial pollution is electronic media (radio and television) and through individuals in their communities. 


\section{Figure 4.14 - Level of concern about types of air pollution}

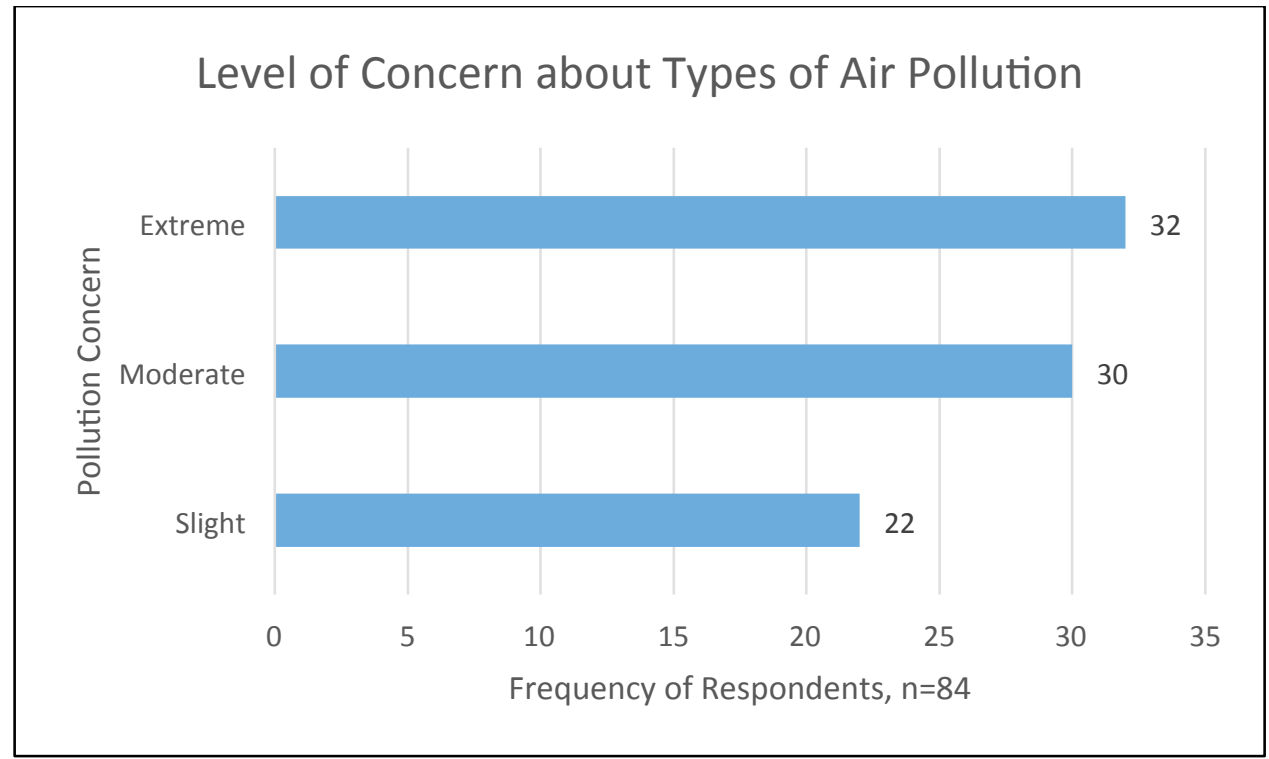

Respondents were also asked whether or not they had any concerns about various types of pollution in their neighborhood. Those reporting concern were also asked to report the level of intensity attached to their concern (i.e., slight, moderate, extreme). Figure 4.14 reveals that thirty-two respondents said they are extremely concerned about air pollution; thirty respondents replied that their level of concern is moderate while twenty-two respondents thought they are slightly concerned about the level of air pollution. 


\section{Figure 4.15 - Types of air pollution that is of major concern}

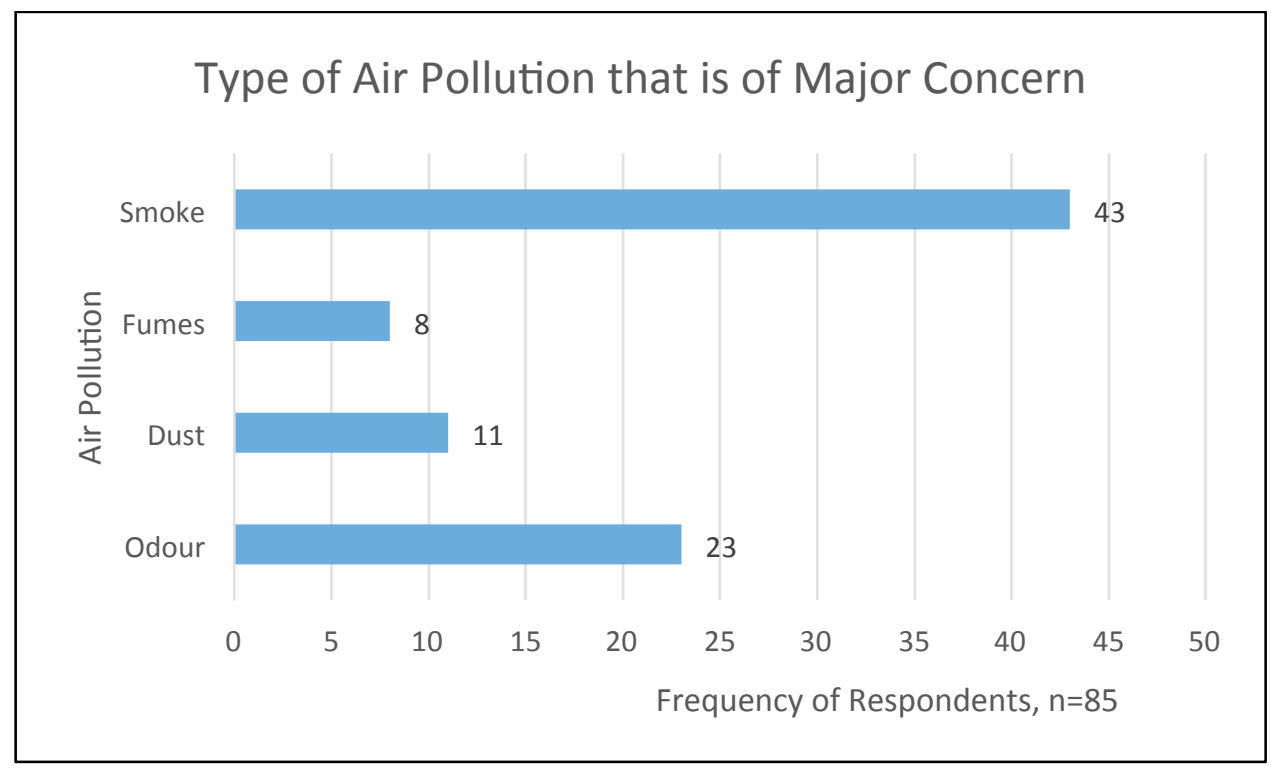

With respect to the types of air pollution that is most concerning, forty-three respondents said smoke is the form of air pollution that is of major concern to the community residents (see Figure 4.15). Twenty-three respondents replied that odour constitutes a major concern among the inhabitants; eleven respondents believed dust is of major concern while eight respondents thought fumes were a major concern. Dust is not a major air pollution problem because there is only one cement based industry (the major source of dust) in Ota. It is obvious that the most important air pollution concern for residents of Ota is smoke. It is noteworthy that during the survey, some community residents informed the researcher that the problem of smoke is worse during weekends than weekdays when there are large scale industrial processes. 
Figure 4.16 - How often about air pollution concern

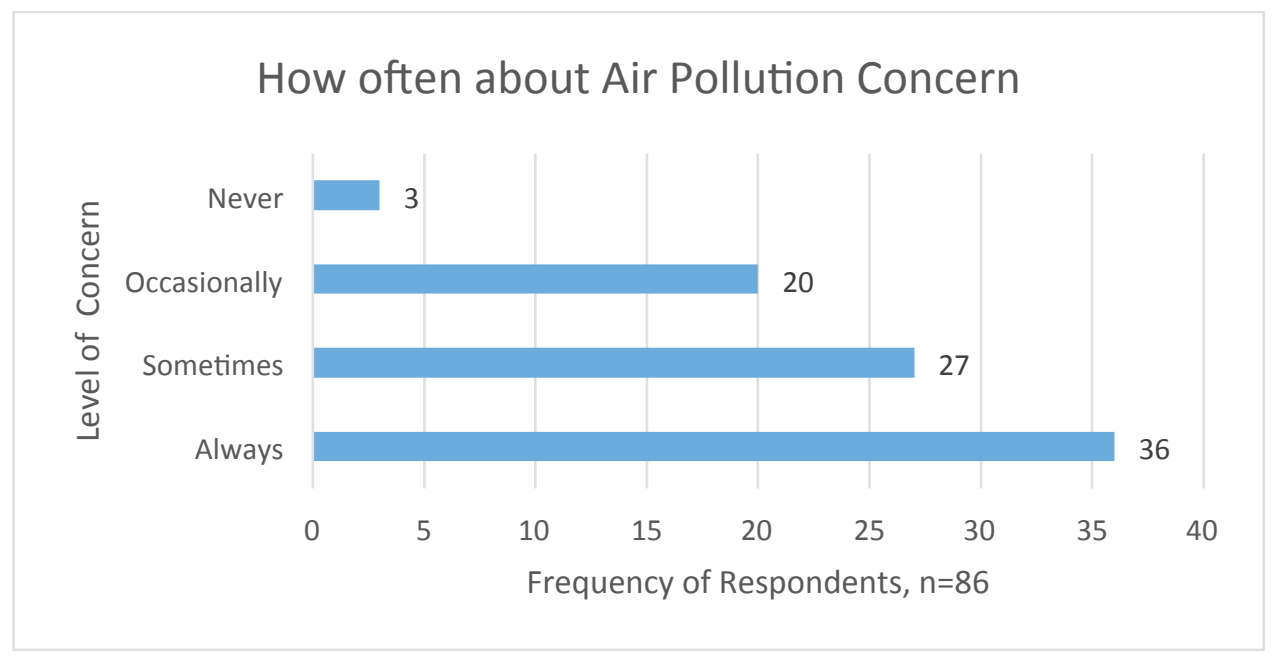

Respondents were also asked how often they are concerned about air pollution. Thirty-six respondents replied that they always have concern about industrial air pollution. Also, twentyseven respondents reported that industrial air pollution is sometimes a concern. Twenty respondents replied that they are occasionally concerned about air pollution. Three respondents replied that industrial air pollution has never been a concern to people living near the industries in Ota.

\section{Figure 4.17 - Notice of noise from industries}

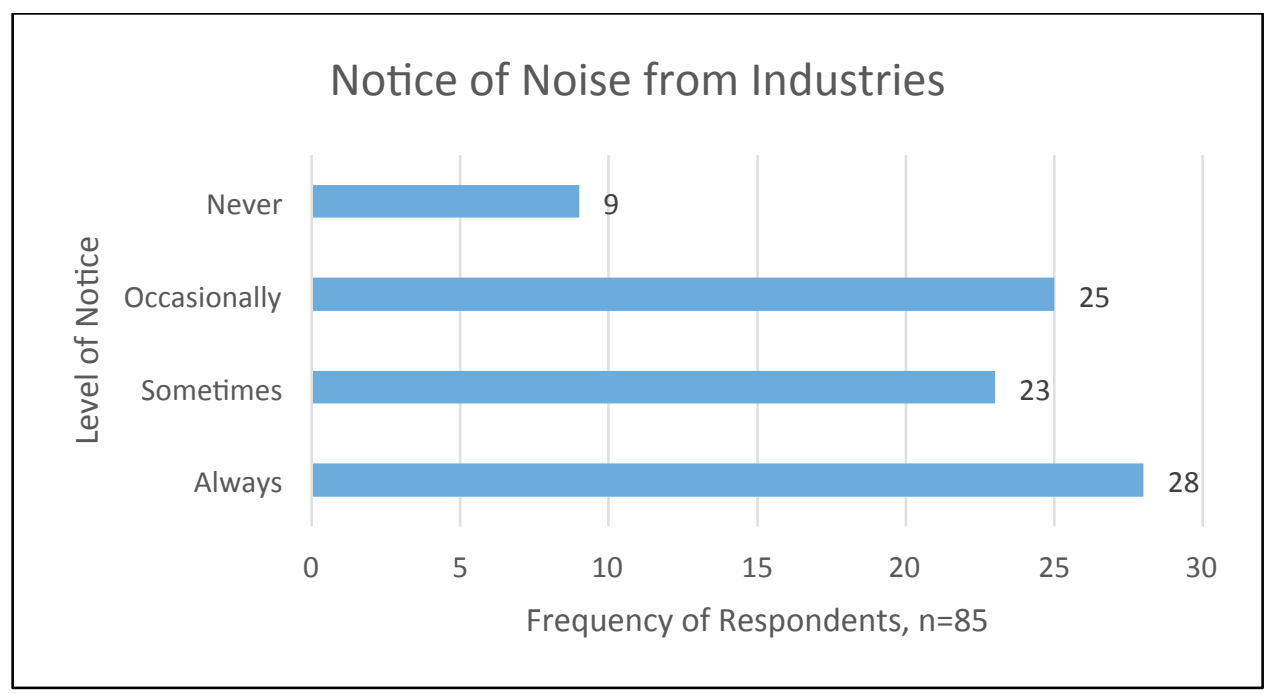


The survey also asked about perceptions of noise pollution. Twenty-eight respondents said they always noticed noise from industries. Twenty-five respondents answered that noise is noticed on occasional basis while twenty-three respondents responded that noise is noticed sometimes from industries. Also, nine respondents said that they have never noticed noise from industries. The implication of this analysis is that a majority (seventy-six respondents) of the inhabitants were aware of the effects of noise pollution generated through industrial equipment while few residents (nine respondents) were not privy to industrial noise pollution in their domain. It is a known fact that residents that are close to the industries are exposed to high noise levels and environmental hazards. The extent of noise pollution is not given much attention in comparison with other types of pollution. For example, Olayinka and Abdullahi (2009) argued that high noise levels have been traditionally taken for granted in industries in developing countries especially Nigeria.

\section{Figure 4.18 - Degree of annoyance of noise}

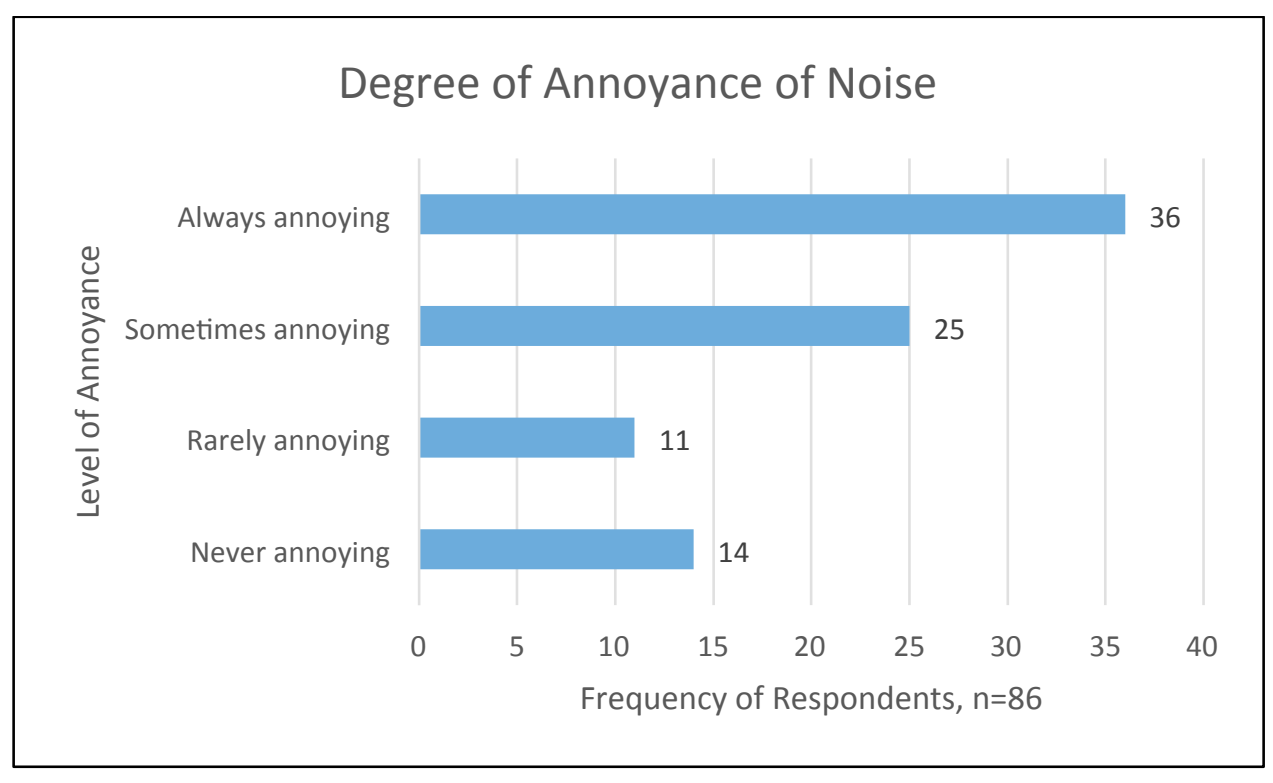

Figure 4.18 shows the frequency of noise pollution. Thirty-six respondents replied that industrial noise is always annoying; twenty-five respondents said noise is sometimes annoying. 
Fourteen people interviewed said noise is never annoying to them while eleven respondents believed that noise is rarely annoying. This assertion agrees with Claeson et al (2012), which found that annoyance involves individual perceptions and attitudes towards the exposure. This might explain why it is not taken as seriously as other pollution concerns.

\section{Figure 4.19 - Concerns about water pollution}

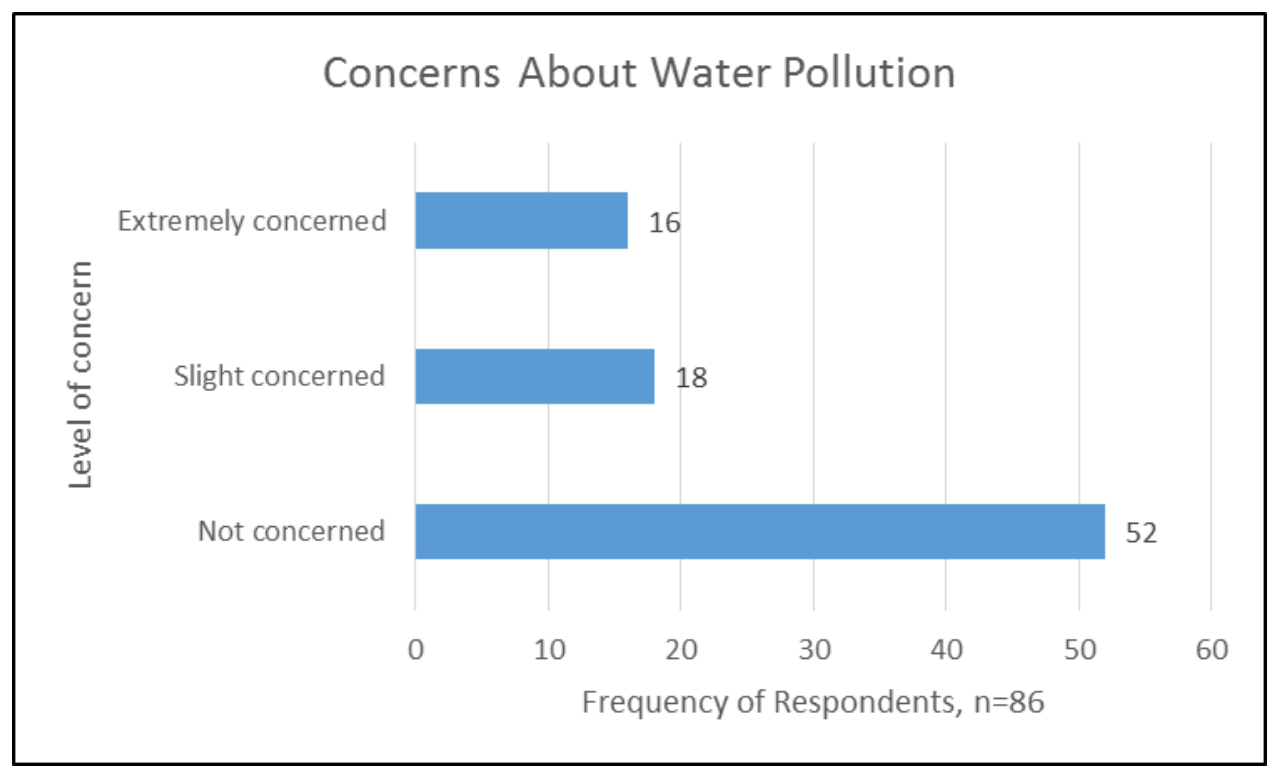

Perceptions of water pollution were also evaluated (Figure 4.19). The findings show that fifty-two respondents are not concerned about water pollution. Also, eighteen respondents said they are slightly concerned while sixteen respondents thought they are extremely concerned. Since majority of the people interviewed said they were not concerned about water pollution in the community, it can be inferred that water pollution is not a serious concern for residents, which was surprising. The result of this study is different with the findings of the research conducted by Adebowale et al. (2011) on the perceived effect of industrial water pollution on the livelihood of rural dwellers in Ota Area, Ogun State, Nigeria. The authors stated that the impact of industrial water pollution is highest in Ado Odo Ota Local Government area where effluents from industries had damaged their water resources and affected their livelihood a great deal. This 
impact is mostly felt in the rural communities or villages where farming is the major occupation of the people. The issue of water pollution might not be a concern because the sampled areas in Ota is distant from the rivers where people could experience the impact of water pollution.

A follow-up open-ended question was asked on the kind of water pollution the residents are most concerned about in the community. Out of the total eighty-seven questionnaires distributed, only twenty-one residents responded as follows: The first category responded on waste water/effluent from industries: sixteen respondents from Ota Township, Ogun State industrial housing estate and Onipanu areas said that the kind of water pollution they were concerned about are sewage from industries, pollution of water bodies e.g. boreholes through indiscriminate wastes dumped on the streets and open spaces in the communities. The wastes percolate through the soil to contaminate the water bodies during rainy seasons thereby making the water unsuitable for domestic uses. In category two, one respondent residing in the industrial housing estate complained that the polluted wells water contains whitish substances which make it improper for drinking and washing purposes. Also, in the third category, three respondents (one from the housing estate and two from Onipanu) replied that they were not concerned about water pollution in their locality. In the last category, one respondent from Onipanu area answered that the lack of proper drainage system by the industries is a concern that make the inhabitants prone to water pollution. 


\section{Figure 4.20 - Concerns about soil pollution}

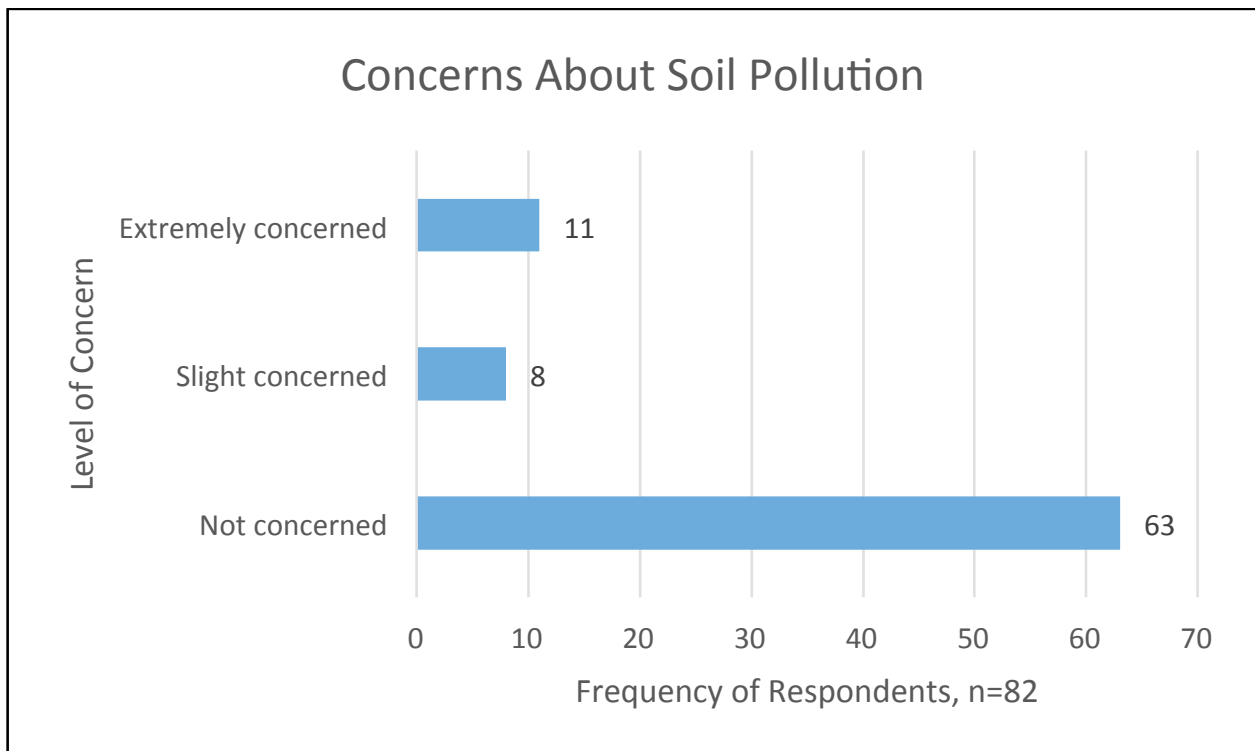

A final area for investigation related to public perception of soil pollution. A majority of the respondents (63) were not concerned about soil pollution in Ota communities. Eleven respondents replied that they were extremely concerned about soil pollution while eight respondents (a small proportion of the total respondents) were slightly concerned about soil pollution. A reason why a majority of the community residents may not be concerned could be due to the fact that their main occupations are trading, government/corporate workers and industrial workers. The implication is that majority are not involved in farming activities where they might experience the negative impacts of soil pollution on agricultural land and crops yield. From the analyses in Figures 16, 19, and 20, it is quite obvious that air pollution is the major environmental problem for Ota residents, particularly relative to other types of pollution (i.e., water and soil), with a particular concern with smoke.

As a follow-up to the questions about the concerns of water/soil pollution, an open-ended question that was asked was: "what are the main sources of water/soil pollution?" Out of the 
eighty-seven questionnaires, eighteen respondents answered this particular question. Their responses are categorized in Table 4.2 .

Table 4.2 Main sources of water/soil pollution

\begin{tabular}{|l|c|}
\hline Response & Frequency \\
\hline Industrial waste/waste water from companies & 14 \\
\hline Heavy truck/chemical spillage & 2 \\
\hline $\begin{array}{l}\text { Improper planning by the industries and negligence of the government } \\
\text { and the residents }\end{array}$ & 1 \\
\hline There are no sources of water/soil pollution & 1 \\
\hline Total & 18 \\
\hline
\end{tabular}

Fourteen respondents said industrial wastes are sources water/soil pollution. Also, the respondents stated that lack of good drainage in their domains enable industrial waste water to be retained on the soil. Concerning pollution through chemical spillage, two respondents believed that industrial pollution in their locality is as a result of heavy trucks transporting chemical substances. One respondent argued that lack of planning and negligence of government contributed to sources of water/soil pollution, while another respondent said there are no sources of water/soil pollution in the community.

\section{Figure 4.21 - Health (Medical) conditions of respondents}

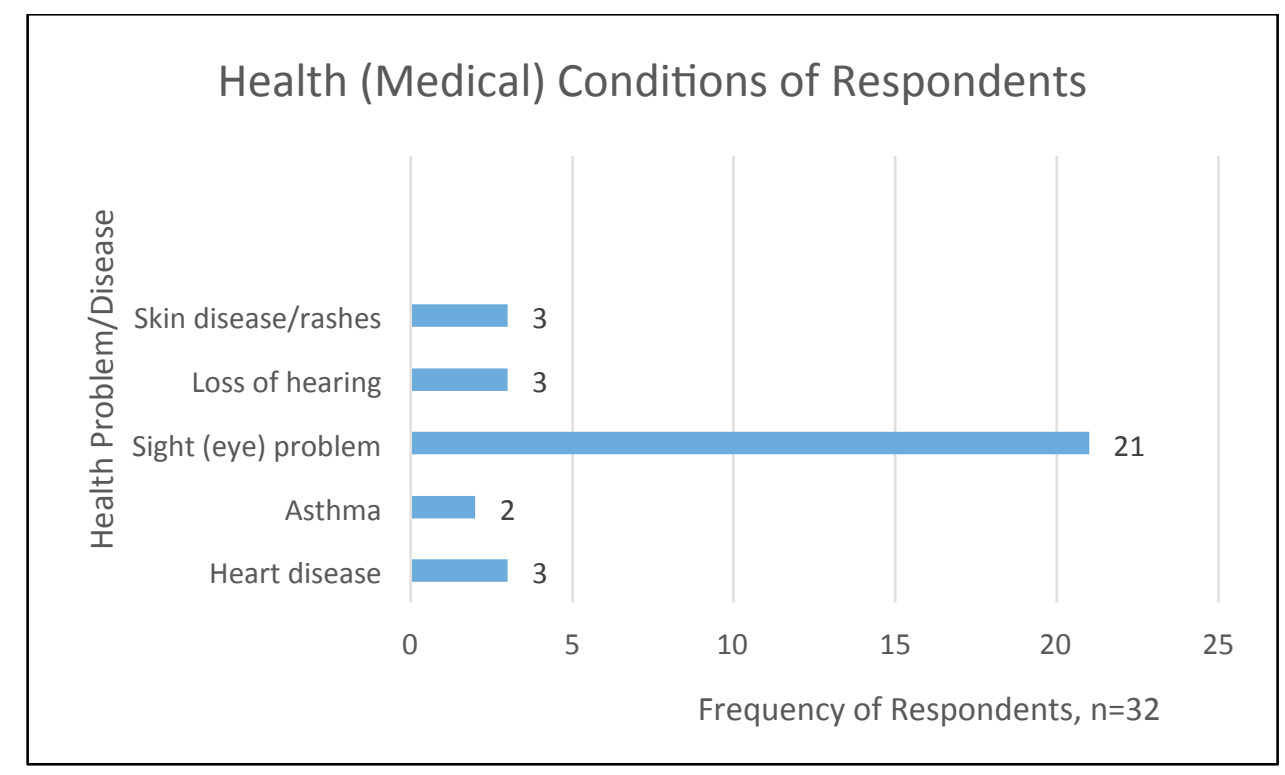


Thirty-two people responded to a question about personal health conditions. Twenty-one respondents complained that they frequently feel irritations in their eyes. Three respondents said they had skin disease/rashes, loss of hearing and heart disease, and, two respondents disclosed having asthma. Hence, from the analysis, five common medical conditions were identified as common to the study area.

It is noteworthy that fifty-five people (more than half of the total respondents) did not respond to the question about their medical conditions. Their reluctance might be due to concern about disclosing personal information or ignorance about personal health conditions due to infrequent medical treatment.

\section{Figure 4.22 - Corporate social responsibility of companies}

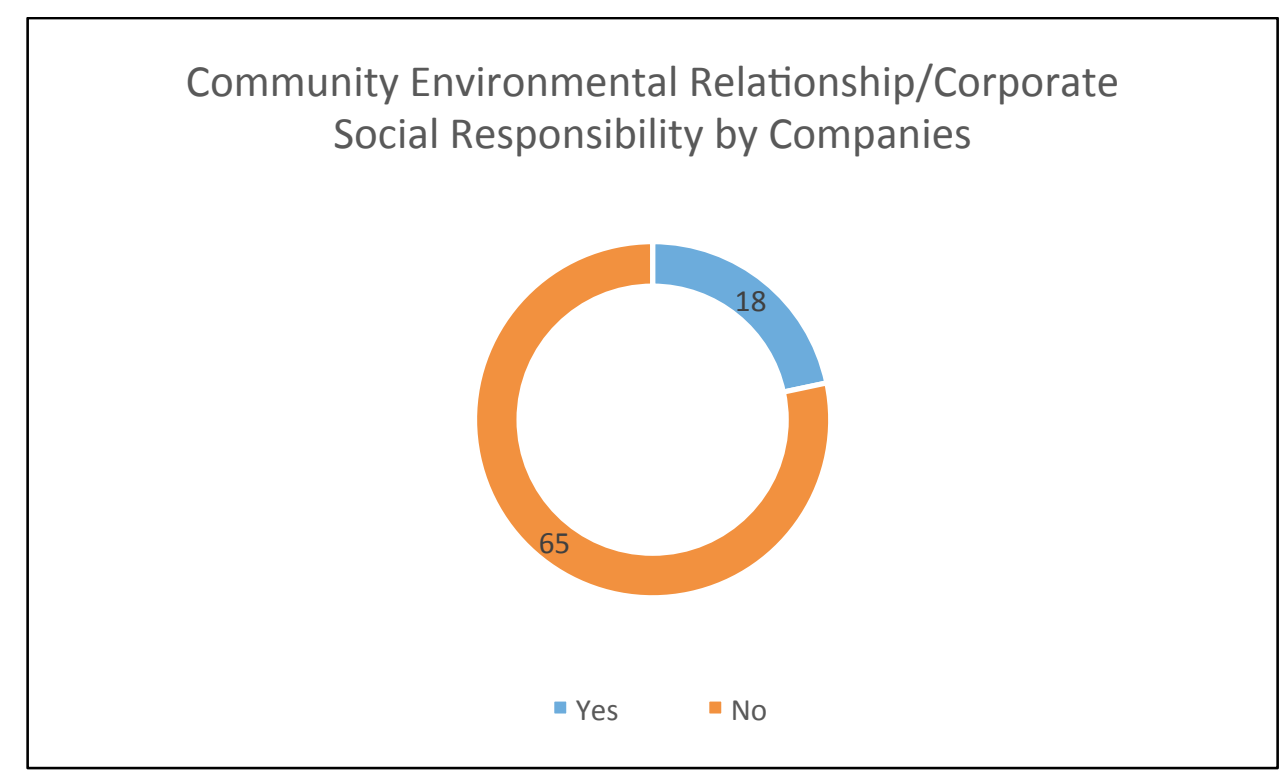

Another community issue that the study examined was whether residents felt industries were involved in environmental stewardship or took responsibility for emissions. Residents were asked to indicate "Yes" or "No" about whether they thought industries were involved in community environmental relationship/corporate social responsibility (CSR). Eighty-three out of eight-seven participants responded; out the total respondents, sixty-five of them indicated that 
the industries are not engaged in CSR to mitigate the effects of pollution. While eighteen of the total respondents said that the industries are involved in community environmental initiatives to alleviate pollution in their domains. During the research it was discovered that community development groups in Ota communities have been very active in attempts to influence the environmental management process. The Executive of a community association informed the researcher that they had reported cases of industrial pollution to the Chairman of Ota local government council and representatives of the State government on several occasions without any action from the authority. However, the residents were also concerned about the thick smoke that is discharged to the atmosphere mostly on weekends when the industries spend longer hours in production processes. They were particularly worried about the impacts of adverse air quality on the health of their households.

Residents who said "Yes" - nearby residents were engaged in corporate social responsibility - were then asked what kind of community development initiatives the companies were engaged in (see Table 4.3).

\section{Table 4.3 Community development initiatives of companies}

\begin{tabular}{|l|c|}
\hline Response & Frequency \\
\hline Charitable donations to the community & 4 \\
\hline Contributions to community environmental and social issues & 8 \\
\hline $\begin{array}{l}\text { Collaborates with government and other stakeholders to address } \\
\text { environmental issues }\end{array}$ & 4 \\
\hline Communicate to the community about implemented initiatives & 16 \\
\hline Total & \\
\hline
\end{tabular}


It is evident from analysis in figure 4.22 that residents do not think companies are doing enough in the community to mitigate pollution and to support communities. This means the industries in Ota communities are not paying attention to the local community to improve their well-being through donations, engaging in projects that can have impact their lives, or collaborate with government and other stakeholders in addressing environmental issues and maintaining effective communication and exchange of ideas with the community residents.

\section{Figure 4.23 - Procedure to deal with industrial pollution complaints}

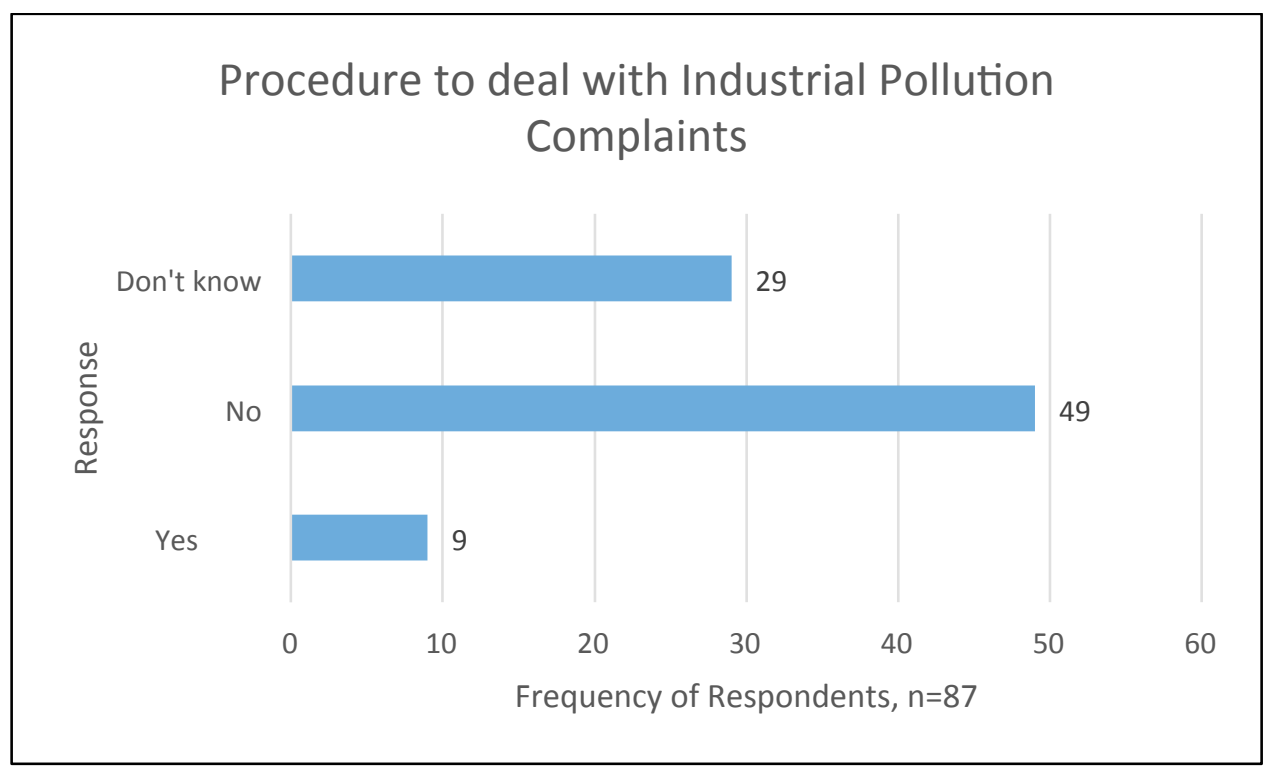

The last set of survey questions related to responses to community concerns about pollution and community perceptions of and relations with government. Forty-nine respondents answered that there is no procedure to address complaints concerning industrial pollution in their locality. Nine respondents said there is a procedure to deal with complaints, while twenty-nine respondents replied they don't know if there is any procedure to deal with industrial pollution complaints. It is likely there is no procedure because some of the industries in Ota might not be interested in discussions with community residents because the community residents lack authority to sanction them unlike government officials that have control over their activities. 
Figure 4.24 - Person that is reported to during environmental concern

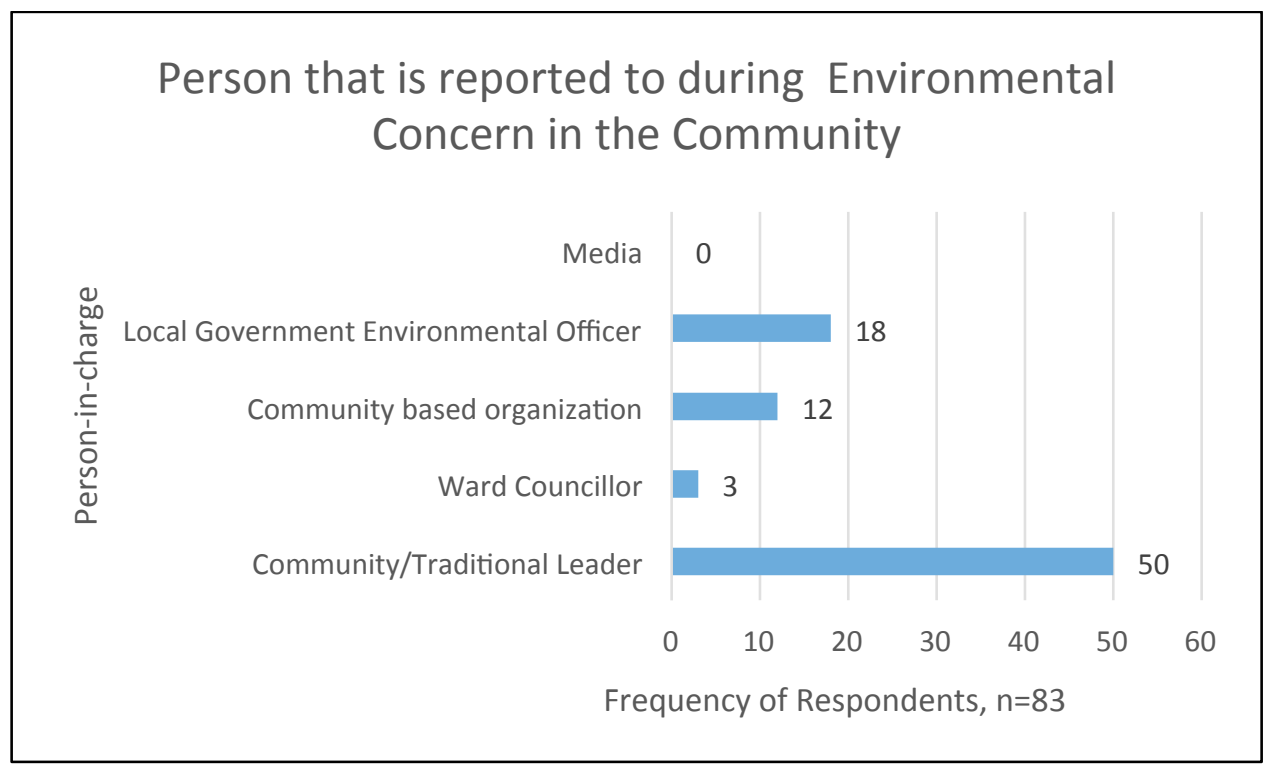

When community members do report concerns, who do they report them? Fifty respondents said that they reported their concern to community/traditional leader; eighteen respondents reported environmental issues to local government environmental officer; twelve respondents channelled their environmental concern through community based organizations, and three respondents reported environmental concerns to their councillor who is their elected representative at the local government council. These results show that residents rely on their community/traditional leaders to address pollution concerns. 
Figure 4.25 - Person or group that directs environmental initiatives

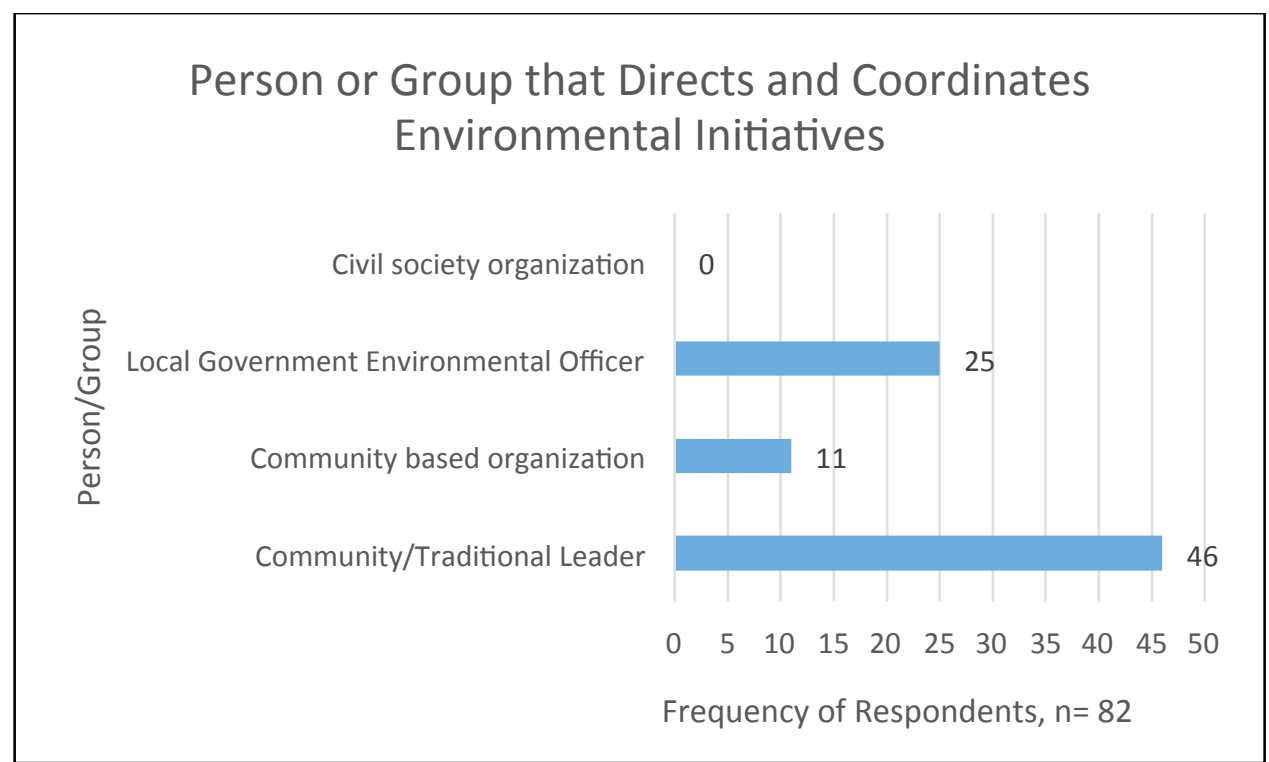

Residents were also asked who in their community takes the lead in coordinating environmental initiatives. Forty-six respondents said that community/traditional leaders coordinate most environmental initiatives. Twenty-five respondents replied that local government environmental officers coordinate environmental initiatives in their communities, while eleven respondents were of the opinion that community based organizations (CBOs) direct environmental initiatives. It is interesting that civil society organizations were not a dominant group coordinating environmental initiatives in the community despite the fact that it is an important environmental stakeholder. This is contrary to the discussion of Henriques and Sadorsky (1999) that a firm's level of environmental pro-activeness is related to high pressure from the community stakeholders such as the non-governmental organizations (NGOs). 
Figure 4.26 - Entity with central responsibility of managing pollution

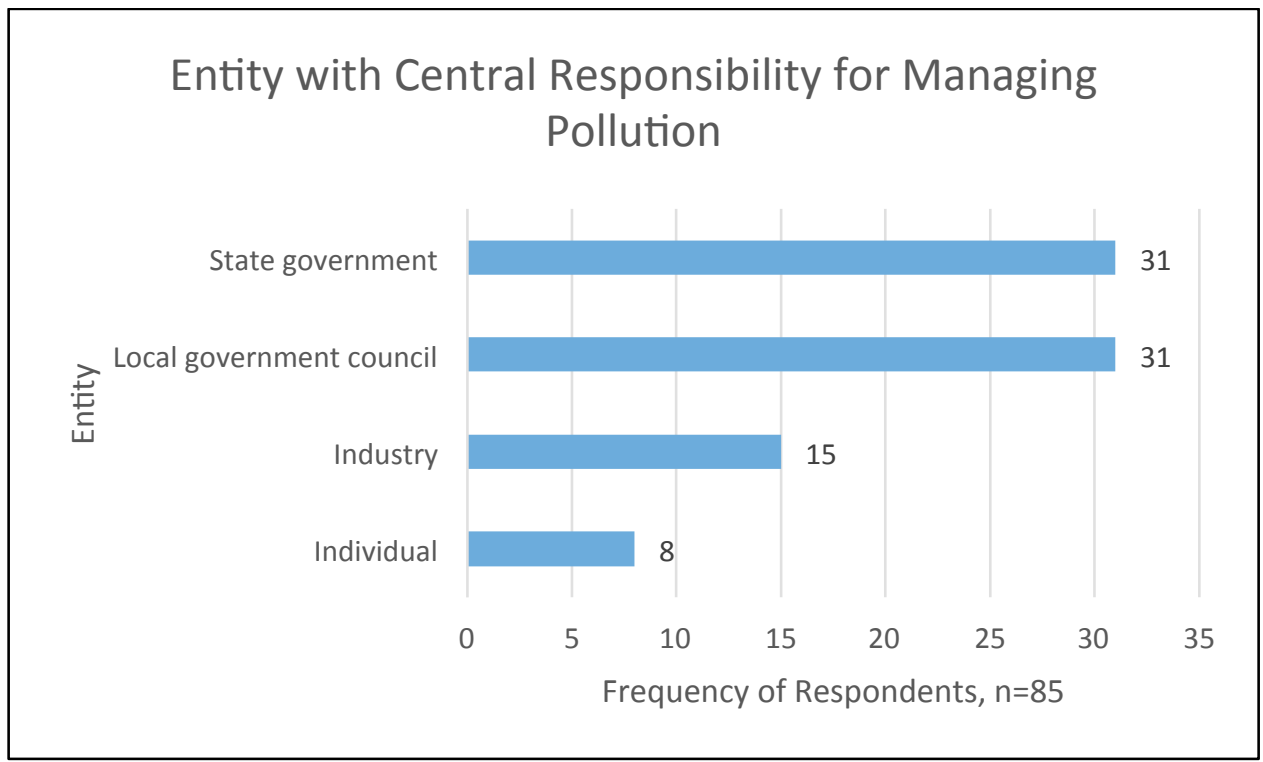

Residents were also asked who they think should have responsibility for addressing pollution. The analysis shows that thirty-one respondents believed that the central responsibility of managing pollution is with the state government. Also, thirty-one respondents said that the central responsibility for pollution management is with the local government council. Fifteen respondents thought it is the responsibility of the industry to manage pollution. This assertion from these participants might be based on the understanding that since the industries cause the pollution, it is their responsibilities to address the problem. Eight respondents answered that individual has the responsibility to manage industrial pollution. These findings, not surprisingly, shows that residents think that both the state and local governments has the major responsibility to manage industrial pollution more that industry. 


\section{Figure 4.27 - Effectiveness of government in managing industrial pollution}

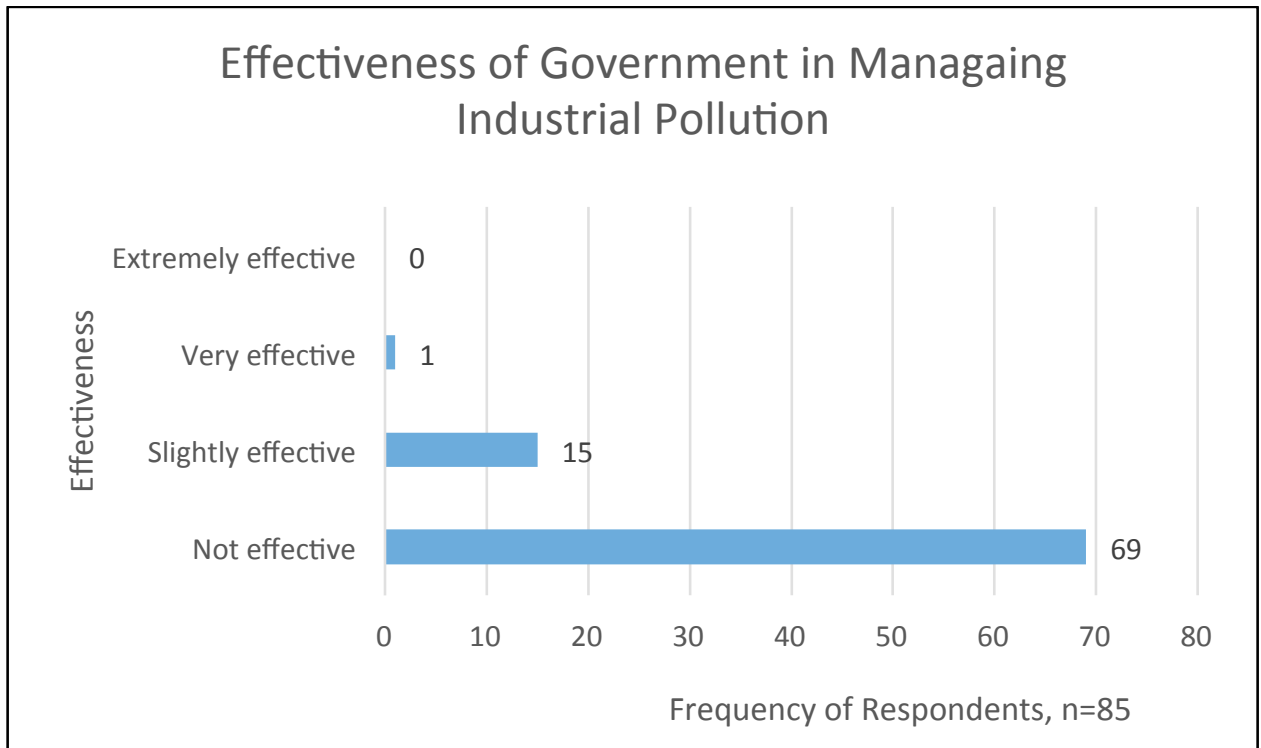

Another important question asked was "how effective is government at managing industrial pollution?" Sixty-nine of eighty-five respondents replied that governments are not effective in managing industrial pollution, while 15 respondents answered that the government is slightly effective in dealing with industrial pollution. One respondent said that the governments have been effective in management of pollution. No respondent said governments have been 'extremely effective' in managing industrial pollution. The results show clearly that residents do not have a lot of confidence in government pollution management. 


\section{Figure 4.28 - Has pollution become better or worse in the last 5 or 10 years?}

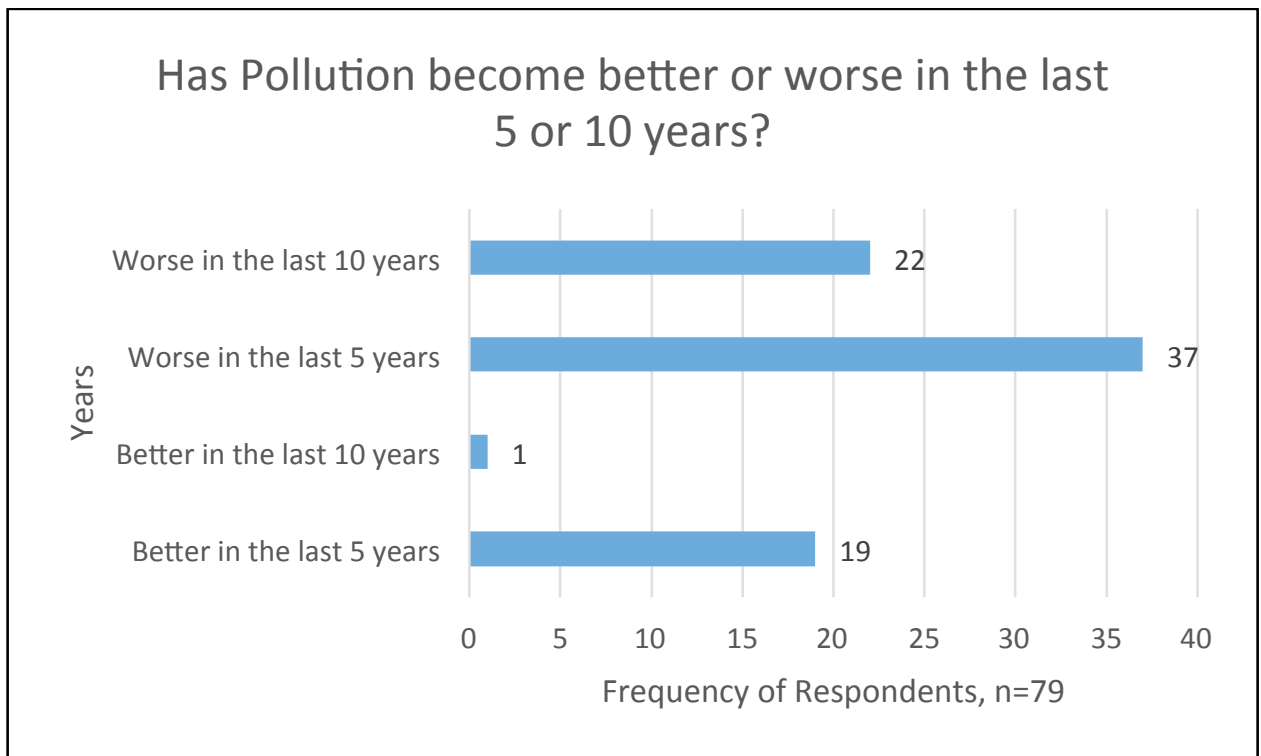

The final question asked to residents was whether they thought pollution has become better or worse in the last five or ten years. Of the respondents, thirty-seven said pollution has become worse in the last 5 years. Also, twenty-two interviewees responded that pollution has been worse in the last ten years while nineteen respondents replied that pollution has been better in the last five years. One respondent, which represents the least amount of respondents, answered that pollution was better in the last 10 years. It can be deduced from the analysis that residents perceive pollution to have become worse in the last 5-10 years.

It is evident from the data that a majority of residents perceive pollution to exist in Ota communities, but the degree or severity of pollution depends on the nearness of these industries to residential houses. The main media through which the residents hear about industrial pollution is electronic media (radio and television) and through individuals in their communities. Perceptions about air, water and soil pollution were evaluated. Smoke is the form of pollution that most affects the residents of Ota. 
The results of the study also showed that people were not concerned about water pollution in the community, which was surprising. This contrasts with the research findings of Adebowale et al (2011) that the impact of industrial water pollution is highest in Ado-Odo/Ota Local Government Area due to industrial effluents. The disconnect between the perception of water pollution and actual water pollution is likely due to the fact that most residents don't require access to rivers or streams for agriculture or drinking. The investigation on public perceptions about soil pollution also affirmed that people were not concerned with soil pollution likely because their main occupations are trading, government/corporate workers, and not farmers where they could experience the negative impacts of soil pollution on agriculture. It is quite obvious that air pollution is the major environmental problem for Ota residents, particularly relative to other types of pollution (i.e., water and soil), with a particular concern with smoke.

Again, the results revealed that residents do not think companies are doing enough in the community to mitigate pollution and to support communities. This implies that the industries in Ota are not paying attention to the local community to improve their well-being through donations, exchange of ideas, engaging in projects, or collaborate with government in addressing environmental issues. Lastly, the results show clearly that residents do not have a lot of confidence in government pollution management.

\subsection{Industry}

This research is meant to elucidate how pollution is addressed by the industries and the projects or activities they employ to improve the living conditions of the people in the community. Ten manufacturing firms were purposely selected in the study area. Senior employees of the companies who were in positions and departments related to environment were chosen to complete questionnaires. The open-ended questionnaires contained thirteen questions 
and were given to the companies' representatives in their offices with each taking approximately 30 minutes on average to complete, and returned to the researcher. The questionnaire was divided into two parts: (1) Information about companies (Questions 1-5). This is presented in Table 4.4., and it include name of companies, number of employees, sector/primary production, and age of companies; (2) issues addressed include environmental concerns/pollution, policy initiatives and corporate social responsibilities (Questions 6-13). The names of the interviewees and the names of the companies they worked for remain anonymous. The sector the company works in is listed, and each firm is listed by letter, e.g., Firm A, B... J.

\section{Table 4.4. Information about Companies}

\begin{tabular}{|c|c|c|c|}
\hline $\begin{array}{l}\text { Name of } \\
\text { Company }\end{array}$ & Sector/Primary Production & Years of Existence & Number of Employees \\
\hline $\mathrm{A}$ & Food Packaging & 6 & 300 \\
\hline B & Wine and Spirit & 5 & Over 300 \\
\hline $\mathrm{C}$ & Pipe and Plumbing Material & 15 & Over 400 \\
\hline $\mathrm{D}$ & Iron and Steel Coils & 29 & Over 300 \\
\hline E & Aluminium Roofing Sheets & 20 & Over 400 \\
\hline $\mathrm{F}$ & Chemical & 25 & Over 600 \\
\hline G & Plastic & 6 & 600 \\
\hline $\mathrm{H}$ & $\begin{array}{l}\text { Corrugated Aluminium } \\
\text { Sheet }\end{array}$ & 10 & 100 \\
\hline I & Wood and wood products & 20 & Over 200 \\
\hline $\mathrm{J}$ & $\begin{array}{l}\text { Cosmetics and Hair } \\
\text { products }\end{array}$ & 16 & Over 100 \\
\hline
\end{tabular}

The sampled industries have been in existence in the community between five to twentynine years. Only company $\mathrm{H}$ is small-scale; A, I and $\mathrm{J}$ are medium-scale; while the remaining six industries B, C, D, E, F and G are large-scale based on number of employees. These categories of firm size are consistent with the Central Bank of Nigeria (2005) classification of industry whereby a labour pool of 11-100 workers is small scale, 101-300 employees is medium-sized and large scale is an industry with a labour size of over 300 workers. 


\subsubsection{Environmental concerns/pollution, policy initiatives and corporate social responsibilities}

This section examines questions 6 to 13, the responses were grouped in themes based on their commonalities, and a summary of the responses for each theme were analysed.

\section{Firm pollution management (Questions 6 and 7)}

The firms' representatives were asked if their companies had a policy for dealing with environmental issues. All the ten respondents said that their companies have policy for dealing with environmental issues. This is not surprising because the industries are required to have a policy to address pollution. In a related question, the companies' employees were asked about the kinds of programs their companies take to deal with industrial pollution. Six respondents replied that their industries have agreements with Ogun State Environmental Protection Agency to dispose wastes on weekly or regular basis. Some industry personnel that were interviewed responded that the wastes are recycled and treated before they are released to the environment. Four respondents replied that the industries engaged in manufacturing practices that help to control various forms of pollution.

\section{Firm compliance and response to regulation (Questions $8,9,10$ )}

The interviewees were asked about the number of activities that are required by regulation, and whether any other pollution management activities are undertaken by their firms. All ten respondents replied that all the activities of the companies to deal with environmental pollution are required by regulation, and they mentioned that there are no independent activities embarked by the companies.

Also, the interviewees were asked how their companies had been affected by environmental policies and regulations. Seven respondents replied that environmental policies 
and regulations have enhanced cleanliness of their immediate environment. Two respondents said environmental policies and programs have not really affected their companies while one respondent said that environmental policies and regulations have been useful to reduce pollution and raise environmental awareness in the community.

All the ten respondents from the companies thought that it was not difficult to comply with government regulations when they were asked if there is difficulty for their companies to stay in compliance with regulations. They gave reasons for the easy compliance as follows: (1) collaboration with OGEPA, and (2) the daily routine work of cleaning of the environment.

\section{Firm relationship with community and government (Questions 11 and 12)}

When questions were asked about firms' relationships with community and government, seven participants said that their relationships with the neighbouring community and the government are cordial. Two respondents replied that they are friendly with the community and the government as a result of their involvement in community developmental projects, their compliance with manufacturing best practices, and their adherence to government regulations.

One respondent said that his company relationship with the government and the nearby community is a little cordial.

Also, a related question about how government could help industries reduce pollution was asked. Five respondents answered that government could help industries reduce pollution through enforcement of laws without favouritism, and proper monitoring of industrial processes. Three respondents believed the government should create awareness, encourage training and participation of employees in environmental matters, while two respondents replied that policy 
formulation and implementation is needed from the government to reduce industrial pollution in Ota communities.

\section{Firm self-assessment (Question 13)}

A final question asked about how companies self-assess their pollution. All the ten interviewees thought that their companies were doing enough to manage pollution. This statement contradicts the perception of sixty-five community residents (out of the total number of eighty-three interviewed) who argued that the industries are not engaged in efforts to mitigate the effects of pollution (see Figure 4.22). These results show there is disconnect between the perceptions of the citizens and the firms, which may lead to future concerns (Esty and Winston 2009).

The analysis of data collected from the industries revealed that all the companies have policies to deal with industrial pollution, and they have working relationships with the Ogun State Environmental Protection Agency for disposal of their wastes. Also, the results of the study showed that environmental activities of the companies are controlled by government regulations - the extent that these are effective was not possible to determine because of the lack of data and information from government. It is evident from the interviews that the companies do not compliance with regulations as difficult. The findings discovered cordial relationships between the firms, the communities, and the governments. Although, the companies claimed involvements in community development projects, the results of data analysis on perceptions of residents on industrial pollution shows that the residents do not feel firms are doing enough in addressing the issue. Since, government is a key stakeholder in environmental management, its efforts and contributions in solving the problems of industrial pollution need to be critically examined. 


\subsection{Government}

The interviews were conducted at the offices of OGEPA in the Ogun State Ministry of Environment Abeokuta, Nigeria. Eight questionnaires which contain fourteen open-ended questions were given to the officials of the Inspection, Monitoring and Compliance Department to complete. The officials from this department were selected to receive the questionnaires because they are in charge of inspection and monitoring of manufacturing firms in the State. Six of the questionnaires were returned to the researcher. The list of interviews completed, information about interviewees and the date is presented in Appendix 9. The responses from the administered questionnaires, and a transcribed in-person interview of the Commissioner for Environment using a tape recorder are as follow:

\subsubsection{Government Officials}

The government officials were asked about the primary contributors or sources of pollution. Out of the six interviewees, three responded that the primary contributor to pollution is poor waste management practices. They said that company wastes are dumped indiscriminately on the streets of the neighbouring residences. Two respondents replied that the primary sources of pollution are: increased industrial growth rate and lack of pollution control facility/abatement devices. One respondent was of the opinion that exhausts from vehicles and noise are the primary contributors to pollution

The interviewees were next asked how the community understands the effects of pollution. Three respondents said that the community are well-informed about the effects of pollution in their immediate surroundings. According to two respondents, the level of understanding of the effects of pollution by the community is average. One respondent answered that the community have little understanding about the effects of industrial pollution. 
A question was then asked about the role of government in communicating pollution risks to the communities. Five out of six respondents responded to this particular question. Three respondents said government communicates pollution risks to the communities through both print and electronic media. They also responded that government engages in public awareness through environmental officers. Two respondents replied that government role in risks communication to the local residents is low. This finding is inconsistent with the community information (see Figure 4.13) because the residents argued that they heard about industrial pollution through electronic media and through individuals. The print media and environmental officers were not mentioned as sources of information for industrial pollution.

The officials also responded to a question about what the Ministry of Environment is doing about industrial pollution in Ota. Three respondents replied that regular official inspections are scheduled to the industries for monitoring and compliance. They also said there is enforcement of laws and regulations; penalties are imposed on corporate defaulters. Again, three respondents replied that OGEPA is committed to evacuate wastes, but more efforts are needed for its efficiency.

The respondents were asked about the national and state regulations that exist to curtail pollution. Three respondents mentioned that NESREA and OGEPA laws are the national and state regulations that exist to reduce pollution. Two respondents said there are regulations to curtail pollution in Ogun State, but they are not enforced, while one respondent did not answer the question. This information about lack of enforcement from the government official contradicts the response of the Commissioner (see 4.3.2 below) that regulations in the state are enforced. 
Question was asked on the effectiveness of the regulations, and two inspectors responded that the regulations are effective; also one respondent believed the regulations are effective, but the level of compliance is relatively moderate. Two respondents said the regulations are not effective as expected while one respondent did not respond to the question at all. It was not clear to the researcher the measure or indicator used by the government officials to know that the regulations are effective.

Concerning compliance with regulations, respondents were asked if it is difficult getting industries to comply. Respondents thought the compliance of industries with regulations are not difficult to achieve because the government mandates them to do so. One respondent said though it is not difficult for industries to comply, but in some cases, there might be compromise between industry operators and the government inspectors. One respondent replied that few industries and investors comply willingly with regulations. Again, two government officials responded that it is very difficult to get industries to comply with regulations due to lawlessness, rather extra efforts is required to get them complied.

On monitoring, questions were asked about how often the officials of the Ministry of Environment monitor the industries to ensure compliance with the laws. The result of the analysis shows that two government inspectors agreed that monitoring of industries is done on quarterly basis; two respondents also said monitoring is not regular - it is done once in six months. While the remaining two interviewees did not respond to the question asked. Also a question was asked on the punishment to companies that violate regulations. All the six respondents said sanction and closure or stop-work-orders are the punishments meted out to corporate polluters that violate regulations. The interviewees said a company could be closed if the offence is big, but if not, a fine is imposed. 
Another question was asked if the Ogun State government collaborates with the federal government and international organizations in achieving environmental sustainability. Five respondents replied "Yes" that Ogun State government has been able to maintain collaborations. One respondent replied that there is "No" collaborations with the federal and international organizations.

The interviewees' were asked if they have additional information about industrial pollution issues. Two out of the six respondents suggested that corporate organizations should put in place devices or measures to mitigate industrial pollution. They also suggested that various organs of government be proactive on environmental issues affecting people who resides close to industries.

The findings to this section show that the government officials believe the primary contributors or sources of pollution is poor waste management. Wen (n.d.) argued that pollutants from industries are divided into three major categories namely gas, solid and water; other pollutant forms include noise and odour. Also, research results showed that communities are well-informed about the effects of pollution; pollution risks to the communities are communicated through electronic and print media; monitoring of companies is not regular, done on a quarterly basis or twice a year. Officials argued that corporate polluters are fined when they violate regulations, and the companies could be closed in the case of a big offence, but no evidence was provided to support this position.

\subsubsection{Commissioner's response (in-person interview)}

The commissioner is a political head that oversees the maintenance of a cleaner and healthier environment in the state. He supervises the Permanent Secretary who is the administrative head and the most senior civil servant in the ministry. Detailed responses from the 
Commissioner is important to ascertain how government address the issues of industrial pollution and environmental management in Ogun State Nigeria.

The commissioner responded to the following questions in the interview.

The Commissioner was asked about the quality of the environment in Ota communities.

Response: "The quality of the environment has been a topical subject because of the fact that Ota community is the industrial hub of the entire West Africa belt and by extension there will be a lot of environmental challenges particular in terms of industrial pollution in such a high density area. The quality might not be perfect, but on a daily basis, the government with the community are being faced with the challenges to manage environmental issue. It is important that the quality is not adversely affected to the level that will affect the health of the people".

Another question I asked was how difficult it is to manage or regulate the balance

between employment from industry and economic development and pollution?

Response: "The state ministry of environment and OGEPA has not been facing much difficulties to manage the balance between employment generated by the industries and pollution because of its environment-oriented programs. We know that whatever we do would have effects on the environment whether positive or negative. We all love globalization and industrialization, but industrialization should be done in a sustainable manner without damaging the environment beyond redemption. When you industrialize; when you come up with policies; if you are turning waste to wealth; in all these situations, employment opportunities are created to make a sustainable living”.

I then asked, how the community understands the effects of pollution:

Response: "The community would certainly not have a perfect understanding of industrial pollution on their immediate environment because it is interpreted as a way of demanding CSR from these companies. When a company is socially responsible, the community tends to forget the negative effects of the activities of that company on the environment. In other words, the CSR is overshadowing the demand and the request for a sustainable living of the residents in the community. It may not be their fault, but they do not have the wherewithal and knowledge to objectively ascertain what constitutes industrial pollution. That is why government position is that the best of CSR cannot negate or erase the need to have a sustainable environment. There are many factors that affects the well- 
being of the people that they do not know because they cannot determine it, the reason why the government educate them. For instance, when a company discharges liquid effluent into the community, the substances could percolate the soil and ultimately affect the nutritional value of the product of the farm. In case of polluted water or borehole, it doesn't translate to the fact that anyone drinking it will die immediately, but it has a gradual effect on the health of people living in that community".

During the interview, the commissioner was asked to explain the role of government in communicating pollution risks, and what the ministry of environment is doing about industrial pollution in Ota communities. The Commissioner said: "The government dialogue with the people and the opinion leaders in the affected communities. The reason for their involvement is to get a feedback on what the government is doing in managing corporate pollution." Concerning what the ministry is doing about industrial pollution, the Commissioner said:

...there are regulatory agencies on the establishment of industries in Ogun State and there are physical parameters and requirements that must be fulfilled before an industry would be allowed to take-off and operate in Ogun State and generally in Nigeria. The case of Ota is special because of the industrial density. The first requirement is the environmental impact assessment which enables the government and the industrialist to know the measure that need to be put in place to mitigate whatever might have been identified as possible environmental challenges. Periodically, it is a must for all industries to submit the environmental audit report; the inspectors visit the industries and take samples, analyzed and identified that the report submitted is in agreement with the result in the field. Also, there is environmental management plan which is a requirement for all pollution emitting industries in the State. There is a national standard which is the minimum set by NESREA, and the domestic standard must not be below the national standard. Ogun State is still maintaining the minimum standard specified by the national government. If a company fail to meet up with the national standard, the government identify the causes of that failure and advised the company on what to do. If after series of appeals there is no remedy to the situation, the company will be sanctioned. There is improvement on the level of enforcement and compliance in industrial pollution in Ogun State, industrialists are now more conscious because they need to improve on their production technology, improve state of machinery and procure modern one - those one that will emit little or no pollution at all. It is a win-win situation because the government make revenue from fines. (Commissioner of Environment, August 2014). 
This response makes it seem like the government is quite proactive, but the interviews with inspectors and community residents suggest there is not a lot of inspection or enforcement going on in Ota.

I then asked about compliance and effectiveness of government regulations on industries. The Commissioner replied that "It is not difficult to get industries to comply with regulations because the operators of the industries only need to be educated on their activities which makes it easier for government officials to monitor. The regulations are effective, the question is enforcement. Some measures have been taken to make sure that those regulations are enforced, and enforcement have been effective". When asked how often monitoring takes place the Commissioner repeated government employee positions: "Monitoring of the companies are done through some parameters on monthly, quarterly or yearly basis", with punishments being standard charges.

Another area of interest was about state collaboration with the federal government and international organizations in achieving environmental sustainability:

Yes, there is collaboration in the State and national level and beyond the shore of the country because pollution has no boundary. A pointer to collaborative efforts of the government was the World environmental day which Ogun State keyed-in to and played prominent role in sensitising the entire citizenry about the need to be environmental conscious. Occasionally, the State and federal government goes out together on monitoring and enforcement activities. The state also involved in meetings and conferences, and collaborates with environmental stakeholders such as the NGOs.

I ended by asking the commissioner if he had additional information on corporate pollution issues that he wanted to share.

The management of the environment is a collective responsibility, and everybody must contribute one thing or the other to make it sustainable. We should all be conscious of the 
environment more than ever before because there is actually nothing we could do outside of the environment, for any activity, the environment is the number one partner. We should also let the people know that the environment is very sensitive, the way we relate with the environment determine to a large extent the way the environment will relate back to us.

One lesson learned from the Commissioner relates to his perception of community relations. The Commissioner mentioned dialogue with the people and opinion leaders as a way of getting feedback on government policies. But his view was not consistent with community residents because they complained about a lack of exchange of ideas and neglect by the government. Collaborative efforts with the federal government and international organizations are desirable, and everybody must make contributions for a sustainable environment.

\subsection{Overview: Pollution Management in Ogun State}

The interview results suggest that Ogun State imposes two types of penalties on corporate polluters: (1) fines and (2) closure of facilities. These results match with Adeoti (2008) that the present nature of industrial pollution control in Nigeria is by command and penalty regulations, and that the use of economic instruments is practically non-existent. Two out of the six officers that were interviewed in the Inspection and Compliance Monitoring Department (ICMD) of the Ministry of Environment, and the Commissioner for Environment indicated that regulations are effective, while two officers said that the regulations are moderate or less effective. Also, two officers said the regulations are not effective. The ineffectiveness of the regulations might be due to monitoring lapses as a result of insufficient resources assigned to compliance inspection, budgetary constraints, and inadequate training of personnel who carry out the inspections (Greenbaum \& Wellington, 2010). During the interview with the government officials, the researcher was given NESREA documents that contained various Federal government of Nigeria industrial regulations, no other industrial pollution data was made available. The absence of 
pollution data might be due to ineffective monitoring and enforcement by the government officials.

Also, in reference to a 2013 Newspaper $^{9}$ interview, the Ogun State Commissioner for the Environment was asked what the government does when a company is found to be violating regulations. The Commissioner responded:

When we see any abnormalities, the first thing is that we call the attention of the company to it, that we have observed something and that they must make sure that they put mechanism in place to correct such. Sometimes we do invite them for meetings where we discuss it because some of those things may not be things they can do immediately probably because those things require huge capital to fix. They make us know the capital involved and how long it can take them to do it. Meanwhile, while they are trying to do that, they will still need to provide palliative measures during that period before they can actually get a lasting solution to it.

The foregoing suggests that some forbearance on the part of compliance officials in the Ministry of Environment may be happening. Greenbaum \& Wellington (2010) in the book "Environmental Law and Policy in Canadian Context" (p.257) stated that forbearance can occur as a result of inaction of regulators if officials are persuaded that the violation poses no serious risk; the costs of compliance would be substantial for the company; and additional time would be required for the company to come into compliance. The decision to refrain from enforcement from the perspective of the regulatory system can be seen to be economically prudent and cost effective. Yet from the public's perspective, forbearance can be likened to being soft on industrial polluters. Industries that comply with the regulations believe that forbearance encourages and even rewards bad behaviour over those who comply with the law (Greenbaum \& Wellington, 2010).

\footnotetext{
${ }^{9}$ National Mirror Newspaper May 24 2013, Nigeria - interview of the former Commissioner for Environment in Ogun State - Dr. Lanre Tejuoso on Acts and Regulations to protect both the environment and its inhabitants in the State
} 
Findings from the analysis of community respondents showed that the government has not been proactive because the expected resources are not committed on the monitoring and enforcement process. Though it is difficult for government in developing nations to spend money on environmental issues due to limited resources, from the responses of the compliance and monitoring inspectors in the Ogun State Ministry of the Environment, it seems government is not keen on committing these expected resources. The response of the Commissioner to the question about what the government is doing about industrial pollution in Ota confirms government attitude to pollution issues.

During the interview session with the Commissioner for Environment, I asked: What is the ministry of environment and OGEPA doing about industrial pollution in Ota axis? The Commissioner responded that there are measures put in place by the government to mitigate the effects of industrial pollution. He further said, "It is a win-win situation because the government makes revenue from fines on companies." The amount of money or revenue made through fines were not disclosed, but the fines are based on standard amount stipulated in the National Environmental Standards and Regulations Enforcement Agency Act. From this statement, it is likely that the government of Ogun State is more interested in revenue generation through company taxes and fines rather than paying serious attention to industrial pollution in the immediate community.

The research also found out that monthly, quarterly and yearly inspections of facilities are supposed to be done by compliance officers of the ICMD. The monthly, quarterly and yearly inspections are not adequate for effective monitoring, compliance and control of industrial pollution in Ota axis. The responses of the Commissioner during in-person interview showed that some institutional measures are put in place to address industrial pollution, but the responses of 
some of the inspectors interviewed contradict government views on this matter. Though monthly inspection could be okay if monitoring is effective, quarterly and yearly inspections are not desirable in Nigerian situation where there are challenges of regulating the activities of industries from polluting the environment. This finding corroborates the assertion made by Amokaye (2012) that under-regulation is more pronounced in Nigeria, and regulators condone pollution activities rather than perform their assignment with full diligence.

\subsection{Lessons Learned}

The objectives of the study were to examine community perceptions of industrial pollution and the policy actions of the state government in controlling and preventing industrial pollution. Some lessons were learned from the research.

The analysis showed that a majority of residents' perceived pollution to exist in Ota communities, but the significance and character of pollution depends on the nearness of these industries to residential houses. Also, the main media through which the residents learn about industrial pollution is electronic media (radio and television) and through individuals in their communities. Perceptions about air, water and soil pollution revealed that people were not concerned about water and soil pollution. Again, air pollution is the major environmental problem for Ota residents, relative to other types of pollution (i.e., water and soil), with a particular concern with smoke. Concerning personal health conditions of respondents, five common medical illnesses were identified in Ota communities.

It was also discovered that companies do not seem to be doing enough to mitigate pollution; companies pay little attention to the local community to improve their well-being or to collaborate with government in addressing environmental issues. Even if the government or companies are proactive, it was evident that residents do not have a lot of confidence in 
government pollution management. Further, while the companies have policies to deal with industrial pollution, and they don't express challenges complying with regulations, their relationship with government seems cordial but not very engaged with community residents.

The research also shows that the government is mostly concerned about solid wastes management and not about other types of industrial pollutants. Monitoring of companies is not regular, it is done on quarterly, twice a year, and yearly basis. Again, corporate polluters are fined when they violate regulations, and the companies could be closed in case of big offences but there is no evidence that this is done. 


\subsection{Chapter Five: Policy Recommendations in Addressing Industrial Pollution}

The Ogun State Ministry of Environment stated that it has put in place pollution management and control measures. This research shows that communities in Ota do not have a lot of confidence in these measures and their relationships with corporations are weak. Based on these research findings, several recommendations can be advanced to address industrial pollution in Ota.

First, in addition to the responsibility of the government, encouragement and support should be given to community based and nongovernmental groups in environmental protection activities. NGOs and community groups in Ota do not currently play a noticeable role in environmental monitoring, but with training and support could play an important future role. Already, Community Based Organizations have made some contributions towards achieving an effective environmental control and management system in Ota. But despite the actions of the CBOs, the communities do not feel knowledgeable or informed about industry or regulatory authority pollution management.

Edoho and Dibie (n.d.), stated that, over the past three decades, environmental policy in Nigeria has ignored the input of citizens. The involvement of Ota community residents in environmental policies and decision making could play an important role in addressing industrial pollution because they stand to benefit from the process. According to Afsah et al. (1996), communities can play powerful roles in pollution control and management. The authors suggested that neighbouring communities can have a powerful influence on plant emission levels. Communities that are richer, better educated, and more organised find ways to enforce environmental norms. From available information, there are no evidences of community protests 
against pollution or industries in Ota and other parts of Ogun State. The research conducted by Aribigbola et al (2012) on assessment of health and environmental challenges of a cement factory on Ewekoro community residents, Ogun State, Nigeria affirmed absence of protests against industries in Ogun State. When residents were asked how they cope with the effects of the pollution, $86.63 \%$ of the total respondents prefer to live with the effects of the pollution, while $1.16 \%$ of the total respondents would prefer to take to protest. But, in the Niger Delta region of Nigeria, there have been cases of ethnic conflicts as a result of environmental pollution caused by the activities of Multinational Oil Corporations, and this has attracted much attention. According to Platform (2011), "since the 1990s, communities have frequently held peaceful protests in response to Shell's environmental injustices in the Niger Delta Region". The women of Edagberi/Betterland community in Rivers State protested against Shell's pollution of their land and water and neglect of their community.

Amokaye (2012) argued that the creation of public awareness through education and incentives in the community is another strategy for achieving compliance with environmental laws. Integration of environmental education into the curricula of primary and secondary schools will enable the children to inculcate environmental norms at earlier stages of their lives, and to understand the basis for its protection. Amokaye stated that the use of mass media will help to inform, educate and mobilise citizens to appreciate the importance of healthy living and protection of the environment. Findings from this research show that the level of awareness of industrial pollution in Ota is high and the main source is through the electronic and print media (Figure 4.11). The government should incorporate environmental education in the curriculum of the secondary schools in Ogun State to educate the youths about the need to be environmentally conscious. 
Also, to secure efficient enforcement strategies to address industrial pollution issues, the use of law as a tool for sustainable development is desirable. A sound environmental law must regulate all the media of pollution and provide for adequate civil remedies and criminal penalties for infringement and provide access to environmental justice and information. The success of each enforcement mechanism depends on how the State exercises its discretion in determining its particular needs and environmental priorities and on choosing the appropriate enforcement method. The law should not unnecessarily interfere with existing positive culture, structure and economic welfare of the people. For example, government policy that unduly imposes strict environmental law will discourage investment and render a majority of the citizens jobless. Similarly, well-functioning public institutions such as regulatory agencies, an efficient court system and administrative agencies that are staffed by trained personnel are needed for obtaining effective enforcement strategies. The existence of an efficient and honest regulatory body for industrial pollution monitoring will ensure the appropriate application of legal rules, especially when its decisions are subject to judicial review (Amokaye, 2012). There are existing laws and regulations in Ogun State and at federal level that needs to be enforced on industries to control pollution.

Industrial pollution can be caused by technical reasons, and the use of obsolete, worn-out or defective facility components (Wen, n.d.). Clean and functional technologies should be promoted alongside better economic incentives to reduce the risks of the adverse effects of pollution on human health and the environment in Ota. In this research it was learned that all the companies mentioned industrial wastes as the only source of pollution from industry; they did not consider the issue of air pollution in that community. While a majority of residents said that air quality was their major concern, not all the residents said the air quality is bad - this suggests 
that some of them might have been used to the air quality, or they don't realise the effects of pollution on their well-being. In order to address the prevailing pollution, the Ogun State government needs to formulate and implement policies to curb emissions and encourage air friendly practices among the populace.

According to Edoho and Dibie (n.d.), many environmental policy interventions in Nigeria are regulatory, and seek to control the activities of both the public and private sectors in areas such as pollution, disposal of hazardous and toxic wastes, and health standards. Such policies, in order to be effective, require adequate funding, and trained staff, who are usually in very short supply .The provision of adequate funding and well trained staff should be a priority of the government of Ogun State to improve enforcement and monitoring.

The cooperation of the three tiers of government is important in the implementation of environmental laws and policies affecting the citizens of Nigeria. As opposed to the present attitudes where Federal, State and Local Governments regard each other as competitors, and jostle for relevance, the administration of the Nigerian state particularly from environmental perspective, must be done in a way to promote cooperation among the tiers of government. Section 11 of the Constitution ${ }^{10}$ provides the constitutional base for mutual cooperation between the Federal and State Governments for effective and sustainable management of the nation's environmental problems. It authorises both the federal and state governments to exercise concurrent powers on matters bordering on maintenance and securing public safety and public order (Amokaye, 2012).

In Ogun State, the Ministry of Environment law of 2004, the Environmental Protection Miscellaneous Agency Regulation of 2005, and Emission Control Regulation of 2012 were

\footnotetext{
${ }^{10}$ Federal Republic of Nigeria Constitution, 1999.
} 
aimed at preventing industrial pollution in the state. The law and regulations are subjected to the federal government NESREA Act. Hence, the problem in Ogun State is not about lack of cooperation between the three tiers of government, but it is about lack of will of the state government to strengthen the capacity of the Local Government Areas, particularly Ado OdoOta Local Government in monitoring and enforcing regulations to prevent industrial pollution.

Egbu (2000) suggested that environmental protection agencies in Nigeria should consider using, in addition to command and control instruments, economic measures for the management of pollution problems. These economic measures could introduce more flexibility, efficiency and cost effectiveness into pollution control efforts. In the context of Ogun State, the environmental policy instruments that are currently being used should be strengthened to improve the regulatory regime. The government should engage in regular environmental inspections (the current monthly, quarterly and yearly visits are not sufficient) of industries in Ota, Ogun State to ensure that there is compliance with environmentally sound practices. And in relation to the findings from this thesis, it needs to more effectively communicate the practices and protocols being used to monitor and share results with communities to increase confidence and clarity. 


\subsection{Conclusion}

The successful implementation, monitoring, and enforcement of the policy options in Ota, Ogun State, Nigeria will not be achieved without the involvement and participation of the community residents who are vulnerable to hazards of industrial pollution. Also, all citizens perceive environmental quality very differently and do not see the government playing a central role in management, even though the government says it is. Effective implementation of the statutes and its regulations requires capacity building in terms of human, technical, and financial capacity. The cooperation of various stakeholders in the protection of the environment and management of natural resources in Nigeria is also needed for an unpolluted environment (Ladan, 2012). Finally, the principal role of government in environmental protection efforts, and the collaborative support of the international agencies will consequently enhance the quality of life of the citizens.

The research findings will be useful to the people of Ota communities, the industries that pollute the environment, and the government of Ogun State. This research shows that there is poor communication between community, industry, and government in Ota. It also shows that a majority of residents have a poor perception of environmental quality, particularly air pollution. The government explained that the quality of the environment in Ota is not perfect, and that the communities are faced with challenges to manage environmental issues. This is further challenged by the fact that companies do not perceive their pollution contribution to be high and that government is not monitoring regularly. Further research in Ota should focus on establishing better baseline air quality indicators and developing better opportunities for company, government, community communication and collaboration. 
Koc (2015) argues that we are facing "a global legitimacy crisis". Environmental crises, regional conflicts, “ widening inequalities, a failing regime of international diplomacy and cooperation, a global economy shaped by corporate greed, decline of state power and local sovereignty, increasing private regulation, and with alarming signs of climate change" people feel powerless. Lack of effective response by governments at the local, regional and national levels or by international rules and regulations worsen this feeling of alienation and powerlessness. "Failure to address key climatic, economic, political and societal challenges at the national and international levels, and lack of trust to key institutions of governance, media, and civil society create an environment of hopelessness, distrust and cynicism leading to a global legitimacy crisis" (Koc, 2015: 21). Koc states that we need a paradigm shift for comprehensive and structural changes in policies that would respond to environmental, social and economic priorities. This requires convincing governments, industry, and elites about the necessity of these changes while at the same time mobilizing and convincing the general public (Koc, 2015: 21). People's feeling of powerlessness and distrust towards existing institutions and agents of power limits our ability to bring change in policy, implement changes, punish violators and convince public about their ability to make a difference with their action or electoral decisions. This feeling of powerlessness produces a serious threat for sustainability.

The findings from this research illustrate the tension between regulation and economic development; Ota needs economic development and relies on industries, so governments and citizens are in a difficult situation for demanding a cleaner environment or less pollution and not undermining the contribution of the company to economic well-being. Given this, it is difficult to achieve sustainable development in Ota because of this tension between economic development and environmental well-being in the community. Agumwanba (1998) argued that inequality is 
manifested in the social, economic and political situation in Nigeria, and, as a result of political interest, industry owners carry out activities and flout regulations meant to protect the environment. Also, in support of unsustainable environment in Nigeria, Oyelakin-Oyelarin (1997) asserted that the clustering of industries creates environmental problems, and subsequently made the attainment of environmental sustainability difficult.

The study conducted by Ejumudo and Nwador (2014) on environmental management and sustainable development in Nigeria's Niger Delta region revealed the existence of poor environmental management of natural resources, lack of commitment to the execution of environmental management policies and absence of sustainable development processes in Nigeria. The concepts of sustainable development and environmental justice have been critically analyzed by some scientists in Nigeria. According to Emejuru and Izzi (2015), the effective operation of environmental laws and legislations through compliance monitoring for sustainable environmental management in Nigeria is constrained by the existence of a high potential for role conflicts. The role conflicts, which involve the Federal Ministry of Environment, other federal and state agencies, professional institutions and individuals in local communities could result in uncoordinated approaches to environmental management and poor sustainable development.

In order to move towards the achievement of sustainable development, the Ogun State government needs to maximize the positive influence of industrial activities on economic and social development, while minimizing the negative impact of production and consumption on the environment. On the other hand, the policy choices of the government of Ogun State should be equitable, and not cause injustice to the society. Everybody must therefore play a part in sustaining our environment, because, if we fail to sustain the environment, the environment too will not sustain us. 


\title{
Appendix 1
}

\section{Ryerson University}

\author{
Verbal Recruitment Script - Community Residents
}

Hello - My name is Olalekan Onilude, and I am a MASc candidate from the department of Environmental Applied Science and Management at Ryerson University Toronto. I'm calling to talk to you about participating in my research study. This is a study about the effects of industrial pollution on the residents and indigenous people in Ota communities of Ogun State. You're eligible to be in this study because you are identified as a community leader/resident.

If you decide to participate in this study, participation involves data collection through survey questions. It should take you approximately 20 minutes to complete the survey. The survey can take place in your residence or another location that is convenient to you. I will ensure participant's confidentiality during the survey.

Remember, this is completely voluntary. You can choose to be in the study or not. If you'd like to participate, we can go ahead and schedule a time for me to meet with you to give you more information. If you need more time to decide if you would like to participate, you may also call or email me with your decision.

This project has received research ethics approval from Ryerson University.

If you have any questions about the research now, please ask. If you have any more questions about this process or if you need to contact me about participation, I may be reached at Telephone Number: \#\#\#-\#\#-\#\#\#\#; oonilude@ryerson.ca

If you know people who are also interested in this research study, forward my phone number and email address, and ask them to contact me.

Thank you so much. 


\section{Appendix 2}

\section{Ryerson University}

Recruitment Letter or Email - Industry

\section{Dear Environmental/Sustainability Manager,}

My name is Olalekan Onilude and I am a MASc candidate from the department of Environmental Applied Science and Management at Ryerson University Toronto. I am writing to invite you to participate in my research study about the effects of industrial pollution on the residents and indigenous people in Ota communities of Ogun State. You're eligible to be in this study because you are a stakeholder in environmental management in the State.

If you decide to participate in this study, participation involves an in-person interview. It should take you approximately 20 to 30 minutes to complete the interview. In the interview I will ask you questions about the programs or actions your company take to deal with industrial pollution; how the company has been affected by environmental policies and regulations; and how your company characterize its relationship with the neighbouring community and the government. The interview can take place in your location of employment or another location that is convenient to you. I would like your voice recorded for the purpose of this research. I will ensure confidentiality of your participation.

Remember, this is completely voluntary. You can choose to be in the study or not. If you'd like to participate, or have any questions about the study, please email or contact me at telephone number: \#\#\#-\#\#-\#\#\#\#; oonilude@ryerson.ca

Thank you so much.

Sincerely,

Olalekan Onilude 


\section{Appendix 3}

\section{Ryerson University}

\section{Recruitment Letter or Email - Government}

Dear Honourable Commissioner/Permanent Secretary/Dr. /Mr. /Mrs. My name is Olalekan Onilude and I am a MASc candidate from the Department of Environmental Applied Science and Management at Ryerson University Toronto. I am writing to invite you to participate in my research study about the effects of industrial pollution on the residents and indigenous people in Ota communities of Ogun State. You're eligible to be in this study because you are a stakeholder in environmental management in the State.

If you decide to participate in this study, participation involves an in-person interview. It should take you approximately 20 to 30 minutes to complete the interview. In the interview I will ask you questions about industrial pollution; the role government have played in controlling the effects of pollution through environmental policies to the benefits of the people in the community. The interview can take place in your location of employment or another location that is convenient to you. I would like your voice recorded for the purpose of this research. I will ensure confidentiality of your participation.

This project has received research ethics approval from Ryerson University.

Remember, this is completely voluntary. You can choose to be in the study or not. If you'd like to participate, or have any questions about the study, please email or contact me at telephone number: \#\#\#-\#\#\#-\#\#\#; oonilude@ryerson.ca

If you know people who are also interested in this research study, forward my phone number and email address, and ask them to contact me.

Thank you so much.

Sincerely,

Olalekan Onilude 


\section{Appendix 4 \\ Ryerson University \\ Consent Agreement Form - Community Residents}

Study title: Industrial land use, environmental issues and policy options in Ota communities of Ogun State, Nigeria

You are invited to participate in a research study. Before you give your consent to be a volunteer, it is important that you read the following information and ask as many questions as necessary to be sure you understand what you will be asked.

Investigator: Olalekan Onilude, MASc Candidate

Purpose of the Study: This study is designed to evaluate the effects of industrial pollution on the residents and indigenous people in Ota communities. Approximately 100 individuals will be interviewed in a randomized manner among four communities.

Description of the Study: Participation in the study involves data collection through survey questions. It should take you approximately 20 minutes to complete the survey. The survey can take place in your residence or another location that is convenient to you.

Risks of Participation: There are risks to participating in this study. If people in government or industry representatives learn that you have talked to me about your experience, or if confidential information you shared among participants in the communities is disclosed, then you might feel threatened or concerned that you will be ostracized and penalized due to your participation. This would have a very bad impact on your livelihood and well-being. To safeguard you, I will therefore not disclose your information to other participants from the community, the industry, and the government.

Benefits of Participation: Your participation in this research project will increase your awareness and knowledge about environmental problems and their effects on people's livelihoods. It will also help identify the gaps between citizen, industry and government perceptions and roles in environmental and pollution management. The hope is that research will help the appropriate authority to formulate policies and strategies to better respond to pollution in future.

Confidentiality: In all cases, survey responses will be kept confidential. The data collected for this study will be used for academic purposes only. Records will be kept strictly confidential and only the investigator, faculty supervisor and Yeates School of Graduate Studies, Ryerson University Toronto will have access to survey data. Data will be stored securely in Nigeria in a locked storage container. The storage of the data will last for 3-6 months or more, from the time the survey is completed to the final phase of data analysis. All audio and written files will be deleted and destroyed after the completion of the project in August 2015. 
Incentives to Participate: You will not be paid to participate in this study.

Participation or Withdrawal: Participation in this study is voluntary. If you decide to be part of this study, you may refuse to answer any particular question or stop participation altogether. Withdrawal will not affect your future relations with Ryerson University. In cases of withdrawal, any data you have provided will not be recorded.

Questions about the Study: If you have any questions about the research now, please ask. If you have questions later about the research, you may contact:

Olalekan Onilude

Telephone Number: \#\#\#-\#\#\#-\#\#\#\#

oonilude@ryerson.ca

\section{Dr. Christopher Gore}

Ryerson University, Toronto

Telephone Number: (416) 979-5000 x2703

chris.gore@ryerson.ca

If you have questions regarding your rights as a participant or about the way the study is conducted, please contact:

Toni Fletcher (toni.fletcher@ryerson.ca).

Ryerson Ethics Board Coordinator

c/o Office of the Vice President, Research and Innovation

Ryerson University

350 Victoria Street

Toronto, ON M5B 2K3

416-979-5000 x7112

Agreement to Participate:

Your signature below indicates that you have read the information in this agreement and have had a chance to ask any questions you have about the study. Your signature also indicates that you agree to be in the study and have been told that you can change your mind and withdraw your consent to participate at any time. You have been given a copy of this agreement. 
You have been told that by signing this consent agreement you are not giving up any of your legal rights.

Name of Participant (please print)

Signature of Participant

Date

Signature of Investigator

Date 


\section{Appendix 5}

Ryerson University

Consent Agreement Form - Industry

Study title: Industrial land use, environmental issues and policy options in Ota communities of Ogun State, Nigeria

You are invited to participate in a research study. Before you give your consent to be a volunteer, it is important that you read the following information and ask as many questions as necessary to be sure you understand what you will be asked.

Investigator: Olalekan Onilude, MASc Candidate

Purpose of the Study: This study is designed to evaluate the effects of industrial pollution on the residents and indigenous people in Ota communities.

Description of the Study: Participation in the study involves an in-person interview. It should take you approximately 20 to 30 minutes to complete the interview. In the interview I will ask you questions about the programs or actions your company take to deal with industrial pollution; how the company has been affected by environmental policies and regulations; and how your company characterize its relationship with the neighbouring community and the government. The interview can take place in your location of employment or another location that is convenient to you.

Risks of Participation: There are risks to participating in this study. If colleagues or superiors know that you have participated in this study and they do not approve of your participation, then your employment status could be negatively affected if you lost employment or were denied promotion and penalized due to your participation. To minimize this potential risk, I will keep your identity and the information you shared confidential.

Benefits of Participation: Your participation in this research project will help to identify the gaps between citizen, industry and government perceptions and roles in environmental and pollution management. The hope is that research will help the appropriate authority to formulate policies and strategies to better respond to pollution in future.

Confidentiality: I will keep any information you convey during interviews confidential. The data collected for this study will be used for academic purposes only. Records will be kept strictly confidential and only the investigator, faculty supervisor and Yeates School of Graduate Studies, Ryerson University Toronto will have access to survey data. Data will be stored securely in Nigeria in a locked storage container. The storage of the data will last for 3-6 months or more, from the time the survey is completed to the final phase of data analysis. All audio and written files will be deleted and destroyed after the completion of the project in August 2015. 
Incentives to Participate: You will not be paid to participate in this study.

Participation or Withdrawal: Participation in this study is voluntary. If you decide to be part of this study, you may refuse to answer any particular question or stop participation altogether. Withdrawal will not affect your future relations with Ryerson University. In cases of withdrawal, any data you have provided will not be recorded.

Questions about the Study: If you have any questions about the research now, please ask. If you have questions later about the research, you may contact:

\section{Olalekan Onilude}

Telephone Number: \#\#\#-\#\#\#-\#\#\#

oonilude@ryerson.ca

\section{Dr. Christopher Gore}

Ryerson University, Toronto

Telephone Number: (416) 979-5000 x2703

chris.gore@ryerson.ca

If you have questions regarding your rights as a participant or about the way the study is conducted, please contact:

Toni Fletcher (toni.fletcher@ryerson.ca).

Ryerson Ethics Board Coordinator

c/o Office of the Vice President, Research and Innovation

Ryerson University

350 Victoria Street

Toronto, ON M5B 2K3

$416-979-5000 \times 7112$

\section{Agreement to Participate:}

Your signature below indicates that you have read the information in this agreement and have had a chance to ask any questions you have about the study. Your signature also indicates that 
you agree to be in the study and have been told that you can change your mind and withdraw your consent to participate at any time. You have been given a copy of this agreement.

You have been told that by signing this consent agreement you are not giving up any of your legal rights.

Name of Participant (please print)

Signature of Participant

Date

Signature of Investigator

Date

Agreement to have the discussion recorded

Your signature below indicates that you have agreed to have your voice recorded for the purpose of this research. You have been told that by signing this consent agreement you are not giving up any of your legal rights.

Name of Participant (please print)

Signature of Participant

Date

Signature of Investigator

Date 


\section{Appendix 6 \\ Ryerson University \\ Consent Agreement Form - Government}

Study title: Industrial land use, environmental issues and policy options in Ota communities of Ogun State, Nigeria

You are invited to participate in a research study. Before you give your consent to be a volunteer, it is important that you read the following information and ask as many questions as necessary to be sure you understand what you will be asked.

Investigator: Olalekan Onilude, MASc Candidate

Purpose of the Study: This study is designed to evaluate the effects of industrial pollution on the residents and indigenous people in Ota communities.

Description of the Study: Participation in the study involves an in-person interview. The interview should take approximately 20 to 30 minutes. In the interview I will ask you questions about industrial pollution; the role government have played in controlling the effects of pollution through environmental policies to the benefits of the people in the community. The interview can take place in your location of employment or another location that is convenient to you.

Risks of Participation: There are risks to participating in this study. If colleagues or superiors know that you have participated in this study and they do not approve of your participation, then your employment status could be negatively affected if you lost employment or were denied promotion and penalized due to your participation. To minimize this potential risk, I will keep your identity and the information you shared confidential.

Benefits of Participation: Your participation in this research project will help to identify the gaps between citizen, industry and government perceptions and roles in environmental and pollution management. The hope is that research will help the appropriate authority to formulate policies and strategies to better respond to pollution in future.

Confidentiality: I will keep any information you convey during interviews confidential. The data collected for this study will be used for academic purposes only. Records will be kept strictly confidential and only the investigator, faculty supervisor and Yeates School of Graduate Studies, Ryerson University Toronto will have access to survey data. Data will be stored securely in Nigeria in a locked storage container. The storage of the data will last for 3-6 months or more, from the time the survey is completed to the final phase of data analysis. All audio and written files will be deleted and destroyed after the completion of the project in August 2015.

Incentives to Participate: You will not be paid to participate in this study. 
Participation or Withdrawal: Participation in this study is voluntary. If you decide to be part of this study, you may refuse to answer any particular question or stop participation altogether. Withdrawal will not affect your future relations with Ryerson University. In cases of withdrawal, any data you have provided will not be recorded.

Questions about the Study: If you have any questions about the research now, please ask. If you have questions later about the research, you may contact:

\section{Olalekan Onilude}

Telephone Number: \#\#\#-\#\#\#-\#\#\#\#

oonilude@ryerson.ca

\section{Dr. Christopher Gore}

Ryerson University, Toronto

Telephone Number: (416) 979-5000 x2703

chris.gore@ryerson.ca

If you have questions regarding your rights as a participant or about the way the study is conducted, please contact:

Toni Fletcher (toni.fletcher@ryerson.ca).

Ryerson Ethics Board Coordinator

c/o Office of the Vice President, Research and Innovation

Ryerson University

350 Victoria Street

Toronto, ON M5B 2K3

416-979-5000 x7112

Agreement to Participate:

Your signature below indicates that you have read the information in this agreement and have had a chance to ask any questions you have about the study. Your signature also indicates that you agree to be in the study and have been told that you can change your mind and withdraw your consent to participate at any time. You have been given a copy of this agreement. 
You have been told that by signing this consent agreement you are not giving up any of your legal rights.

Name of Participant (please print)

Signature of Participant

Date

Signature of Investigator

Date

Agreement to have the discussion recorded

Your signature below indicates that you have agreed to have your voice recorded for the purpose of this research. You have been told that by signing this consent agreement you are not giving up any of your legal rights.

Name of Participant (please print)

Signature of Participant

Date

Signature of Investigator

Date 


\section{Appendix 7}

\section{Survey Questions}

Department of Environmental Applied Science and Management, Yeates School of Graduate Studies, Ryerson University, Toronto Canada

Name of Investigator: Olalekan Onilude; E-mail:oonilude@ryerson.ca, leckon2@yahoo.com

This questionnaire aims to gather information about the industrial land use, environmental issues and policy options in Ota Communities of Ogun State Nigeria.

All information from this survey will be kept confidential and will not be used for any purpose other than academic. The data gathered will not be linked with your name in any way.

Thank you very much for the generous and valuable contribution of your time and energy.

COMMUNITY PEOPLE

Profile of Participant

Question \# 1

Sex

[] Male [ ] Female

Question \# 2

How old are you?

[ ] Less 30 [ ] 31-40 [ ] 41-50 [ ] 51-60 [ ] Above 61

Question \# 3

What is your occupation?

[ ] Farmer [ ] Civil servant/corporate worker [ ] Industrial worker

[ ] Trader [ ] Retiree [ ] Unemployed [ ] Other (please specify)

Question \# 4

Educational Qualification:

[ ] No formal [ ] Primary

[ ] Secondary [ ] Post-secondary

Question \# 5

What is your residential location?

[ ] Ota Township [ ] Ogun State Housing Estate Ota

[ ] Sango Ota [ ] Onipanu/Iju Ota 
Question \# 6

What is your residential status?

[ ] Personal ownership [ ] Family/Inheritance ownership

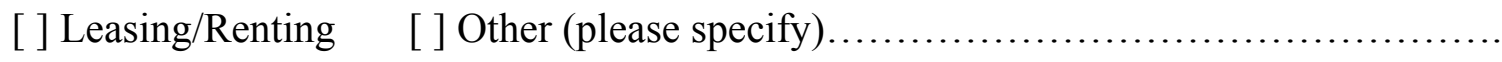

Question \# 7

How long have you resided in this community?

[ ] Less than 10 years [ ] 10-20 years [ ] 21-30 years

[ ] 31-40 years [ ] 41-50 years [ ] Above 50 years

Question \# 8

What is the distance of your residence to the nearest industry?

[] Less than 100m [] 100-200m

[ ] 300-400m [ ] Further than 500m

Question \#9

How large is the nearest industry to you?

[ ] Small-scale (11-100 employees)

[ ] Medium-scale (101-300 employees)

[ ] Large scale (over 300 employees)

Question \# 10

What type of industry? Check whichever is applicable

[ ] Food, beverage and tobacco [ ] Chemical/Pharmaceutical and paint [ ] Textile

[ ] Woods and wood products [] Paper and printing [ ] Plastic and rubber

[ ] Basic metal, iron, steel and fabricated metal [ ] Non-metallic products including Cement

[ ] Vehicle and mechanical works

Question \# 11

Do you think the industries near you pollute the environment?

[] Yes, a lot

[] Yes, a little

[ ] No, not very much

Then, if Yes, go to the next question. 
Question \# 12

Through which media have you heard about industrial pollution? Select all that apply.

[] Radio [ ] Television [ ] Internet [ ] Newspapers

[ ] People (family, friends, environmental professionals) [ ] None

\section{INDUSTRIAL POLLUTANTS}

Question \# 13

I now want to ask you about your perception of the levels of pollution from industry near you.

In your opinion, what is the level of industrial pollution in your community?

$$
\text { High Medium Low No polluted }
$$

Air pollution

Soil pollution

Water pollution

Noise pollution

Question \# 14

Evaluate the level of your concern about various types of air pollution

[] Slight [ ] Moderate [] Extreme

Question \#15

Which type of air pollution is of major concern?

[] Odour [] Dust [ ] Fumes [] Smoke

Question \#16

How often are you concerned about air pollution?

[ ] Always [ ] Sometimes

[ ] Occasionally [ ] Never

Question \#17

How often do you notice noise from the industries?

[ ] Always [ ] Sometimes

[ ] Occasionally [ ] Never 
Question \# 18

To what degree does this noise annoy you?

[ ] Never annoying [ ] Rarely annoying

[ ] Sometimes annoying [ ] Always annoying

Question \# 19

Do you have any concerns about water pollution in this community?

[ ] Not concerned

[ ] Slight concerned

[ ] Extremely concerned

Question \# 20

If you are concerned about water pollution, what kind of water pollution are you most concerned about?

Question \# 21

Do you have any concerns about soil pollution in this community?

[ ] Not concerned

[ ] Slightly concerned

[ ] Extremely concerned

Question \# 22

What do you think are the main sources of water/soil pollution?

Question \#23

Do you suffer from any of the following medical conditions? Check all that apply.

[] Heart disease

[ ] Tuberculosis

[] Asthma

[ ] Sight (eye) problem

[ ] Loss of hearing

[ ] Skin disease/rashes 
Community Environmental Relationship/Corporate Social Responsibility

Question \#24

Is the industry in your neighbourhood engaged in community development initiatives?
[] Yes
[] No
If Yes, check all that apply

[ ] Charitable donations to the community

[ ] Contributions to community environmental and social issues e.g. projects that aim to improve community well-being or health

[ ] Collaborates with government and other stakeholders to address environmental issues

[ ] Communicate to the community the environmental impacts and management initiatives implemented at the industry

Question \# 25

Does the industry have a procedure to deal with complaints about pollution?

[] Yes

[] No

[ ] Don't know

Question \# 26

If there is a problem or concern in the community, who do you report to?

[ ] Community/Traditional Leader

[ ] Ward Councillor

[ ] Community based organization

[ ] Local Government Environmental Officer

[ ] Media

Question \# 27

Is there a person (s) or group assigned responsibility for directing and coordinating environmental initiatives in the community? Check all that apply.

[ ] Community/Traditional Leader

[ ] Community based organization

[ ] Local Government Environmental Officer

[ ] Civil society organization 
Question \#28

Who do you think should have central responsibility for managing pollution?

[ ] Individual

[ ] Industry

[ ] Local government council

[ ] State government

Question \#29

How effective is government at managing industrial pollution?

[] Not effective

[] Slightly effective

[ ] Very effective

[ ] Extremely effective

Question \#30

Has pollution become better or worse in the last 5 or 10 years?

[ ] Better in the last 5 years

[ ] Better in the last 10 years

[] Worse in the last 5 years

[] Worse in the last 10 years 


\section{Appendix 8}

Interview Guide for Industry

1. Name of Industry

2. Primary production.

3. Location of Industry

4. How long has your industry been here?

5. How many employees?.

6. Has your company formulated a policy for dealing with environmental issues?.

7. What kinds of programs or actions does your company take to deal with environmental concerns or pollution from industry?.

8. How many of these activities are required by regulation? How many of these are independent activities by industry?

9. How has your company been affected by environmental policies and regulations?

10. How difficult is it to stay in compliance with regulations?

11. How do you characterize your relationship with the neighbouring community and the government?

12. How do you think the government could help industries reduce pollution?

13. Overall, do you think your company is doing enough in managing pollution?. 


\section{Appendix 9}

\section{Interview Guide for Government}

1. Overall, what do you think about the quality of the environment in Ota communities?........

2. What do you think are the primary contributors or sources to pollution?

3. How much of the environmental conditions in Ota do you think is due to pollution from industries?

4. How difficult is it to manage or regulate the balance between employment from industry and economic development and pollution?

5. How well do you think the community understands the effects of pollution.

6. What is the role of government in communicating pollution risks to the communities?.......

7. What is the ministry of environment and OGEPA doing about industrial pollution in Ota axis?

8. What national and state regulations exist to curtail pollution?

9. How effective are the regulations?

10. How difficult is it to get industries to comply with regulations?

11. How often do you monitor these industries to ensure compliance with the laws?

12. What is the punishment to companies that violate regulations?

13. Does the government collaborate with the federal government and international organizations in achieving environmental sustainability?.

14. Do you have anything you would like to add about corporate pollution issues?

List of Interviews (Ministry of Environment, Ogun State Nigeria)

\begin{tabular}{|l|l|l|}
\hline Interviewee/Respondent & Title/Position at time of Interview & \multicolumn{1}{c|}{ Date } \\
\hline Engineer Ayo Olubori & Commissioner for Environment & August 19, 2014 \\
\hline Anonymous & $\begin{array}{l}\text { Director, Ogun State Environmental } \\
\text { Protection Agency (OGEPA) }\end{array}$ & August 18, 2014 \\
\hline Anonymous & Senior Officer, OGEPA & August 18, 2014 \\
\hline Anonymous & $\begin{array}{l}\text { Compliance/Monitoring Officer, } \\
\text { OGEPA }\end{array}$ & August 18, 2014 \\
\hline Anonymous & $\begin{array}{l}\text { Compliance/Monitoring Officer, } \\
\text { OGEPA }\end{array}$ & August 18, 2014 \\
\hline Anonymous & $\begin{array}{l}\text { Compliance/Monitoring Officer, } \\
\text { OGEPA }\end{array}$ & August 18, 2014 \\
\hline Anonymous & $\begin{array}{l}\text { Compliance/Monitoring Officer, } \\
\text { OGEPA }\end{array}$ & August 18, 2014 \\
\hline
\end{tabular}




\section{References}

Adams, D., Russell, L. \& Clare, T. (1994). Land for Industrial Development. Ibadan: Longman Nigeria Limited.

Adamson, K. Y. (1996). Towards an Environmental Action Plan for Ogun State. Federal Republic of Nigeria, Federal Environmental Protection Agency (FEPA). Final Report.

Adebayo, M.A \& Oni, A. O. (2011). Neighbourhood Effects of Sustainable Industrial Land Use on Property Values: Case Study of Agbara, Ogun State, Nigeria. Journal of Sustainable Development, 4 (6), 230-238.

Adebowale, O., Adebowale, O. O. and Oyesola, O. B. (2011). Perceived Effect of Industrial Water Pollution on the Livelihood of Rural Dwellers in Yewa Area, Ogun State, Nigeria. European Journal of Social Sciences, 22 (1).

Adelegan, J. (2008). Environmental Compliance, Policy Reform and Industrial Pollution in Sub-

Saharan Africa: Lessons from Nigeria. Proceedings of the International Network for Environmental Compliance and Enforcement's (INECE) Eighth International Conference, Linking Concepts to Actions: Successful Strategies for Environmental Compliance and Enforcement, held 5-11 April 2008, in Cape Town, South Africa.

Adeoti, J. O. (2008). Environmental policy and industrial response in Nigeria. International Journal of Technology Management and Sustainable Development, 7 (2), 119-136.

Afsah, S., Laplante, B. and Wheeler, D. (1996). Controlling industrial pollution: a new paradigm. The World Bank.

Aguayo, F., Gallagher, P., and Gohzalez, A. (2001). Dirt is in the eye of the beholder: The World Bank air pollution intensities for Mexico. Global development and environment institute working paper, 0107.

Alli, F. "Nigeria joins ISO 26000 social responsibility countries," (Online) July, 2013. http://www.vanguardngr.com/2013/07/nigeria-joins-iso-26000-social-responsibilitycountries/ (visited: July 18, 2015).

Aribigbola, A., Fatusin, A. F. and Fagbohunka, A. (2012). Assessment of Health and Environmental Challenges of Cement Factory on Ewekoro Community Residents, Ogun State, Nigeria. American Journal of Human Ecology, 1 (2), 51-57.

Agunwamba, J. C. (1998). Solid Waste Management in Nigeria: Problems and Issues. Environmental Management, 22(6), 849-56. 
Al-Khashman, O. A. \& Shawabkeh, R. A. (2006). Metals distribution in soils around the cement factory in Southern Jordan. Environmental Pollution, 140 (3), 387-394.

Amiard, J. C., Amiard-Triquet, C. and Meayer, C. (1995). Experimental study of bioaccumulation, toxicity, and regulation of some trace metals in various estuarine and coastal organisms," in Proceedings of the Symposium on Heavy Metals in Water Organisms, J. Salanki, Ed., pp. 313-324, Akademiai Kiado, Budapest, Hungary.

Amokaye, O. G. (2012). Environmental Pollution and Challenges of Environmental Governance in Nigeria. British Journal of Arts and Social Sciences, 10 (I).

Anderson, P. J. (2004). The social context for harvesting Iriartea deltoidea (Arecaceae). Economic Botany, 58, 410-419.

Balogun, F. (August 2014). Ogun State: Nigeria's New Industrial Hub. (Online) The NEWS. http://thenewsnigeria.com.ng/2014/08/14/ogun-state-nigerias-new-industrial-hub/ (visited: June 20, 2015).

Bashorun, O. (2003). Basic Elements of Urban and Regional Planning. Akure: Shalom Publishers.

Baylis, R., Connel, L., \& Flynn, A. (1998). Company Size, Environmental Regulation and Ecological Modernization: Further Analysis at the level of the Firm. Business Strategy and the Environment, 7, 285-296.

Bernard, H. R. (2002). Research Methods in Anthropology: Qualitative and quantitative methods. 3rd edition. AltaMira Press, Walnut Creek, California.

Braden, B. \& Leys, C. (1994). African capitalist in African development. Boulder: L. Rienner Publishers.

Britten, N. (1995). Qualitative interviews in medical research. British Medical Journal, 311, 2513.

Brundtland Commission (1987). Report of the World Commission on Environment and Development. United Nations

Buzzelli, D.T. (1991). Time to structure an environmental policy strategy. Journal of Business Strategy 12(2), 17-20.

Canadian International Development Agency (CIDA) (1992). CIDA's Policy for Environmental Sustainability. Retrieved May 28, 2015 from http://www.acdicida.gc.ca/INET/IMAGES.NSF/vLUImages/Policy2/\$file/ENV-nophotos-E.pdf 
CBN (2005). Statistical Bulletin.

Chapman, K. \& Walker, S. (1991). Industrial Location Principles and Policies, 2nd ed. India: Wiley Eastern Limited.

Claeson, A. S.; Nordin, M.; Liven, E.; Nordin, S. (2012). The role of perceived pollution and health risk perception in annoyance and health symptoms: A population-based study of odorous air pollution. Int. Arch. Occup. Environ. Health, 83, 367-374.

Clarkson, M. (1995). A Stakeholder Framework for Analysing and Evaluating Corporate Social Performance. Academy of Management Review 20(1), 92-117.

CPMS (Comprehensive Project Management Services). (2005a). Ogun State Regional Plan: Development Pressure Area Planning Zone 2.

Dasgupta, S., Lucas, E. B. and Wheeler, D. (2000). Small plants, pollution and poverty: New evidence from Brazil and Mexico. Policy Research working paper, No. 2029.

De Bartolomeo, A, Poletti, L., Sanchini, G., Sebastiani, B., and Morozzi, G. (2004). Relationship among parameters of lake polluted sediments evaluated by multivariate statistical analysis. Chemosphere, 55 (10), 1323-1329.

Deepali, K. K. \& Gangwar, K. (2010). Metals concentration in textile and tannery effluents, associated soils and ground water. New York Science Journal, 3 (4), 82-89.

Dempwolf, C. S. (2009). An Evaluation of Recent Industrial Land Use Studies: Do Theory and History Matter in Practice? University of Maryland, College Park. communityinnovation.berkeley.edu/.../A_Review_of_Industrial_Land_U...

Edoho, F. \& Dibie, R. (n.d). Executing Environmental Policy and Waste Management in Ghana and Nigeria. http://www.jsd-africa.com/Jsda/Fallwinter2000/articlespdf/ARCExecuting\%20Environmental\%20Policy\%20and\%20Waste\%20Management $\% 20 \mathrm{in} \% \mathrm{~A} 1$ $\%$ AD.pdf?pdf

Egbu, A. U. (2000). Constraints to effective pollution control and management in Nigeria. The Environmentalist, 20, 13-17

Ejumudo, K. B. O. \& Nwador, F. O (2014).Environmental Management and Sustainable Development in Nigeria's Niger Delta. Journal of Economics and Sustainable Development, 5 (15).

Emejuru, C. T. and Izzi, M.O. (2015). Environmental Justice and Sustainable Development in Nigeria. Donnish Journal of Biodiversity and Conservation, 1(1) 001-005. 
Esty, D. C. (1999). Toward Optimal Environmental Governance. New York University Law Review, 74 (6), 1508-1515. Retrieved May 28, 2015 from http://digitalcommons.law.yale.edu/cgi/viewcontent.cgi?article=1439\&context=fss_paper $\mathrm{s}$

Esty, D. C., \& Winston, A. S. (2009). Green to Gold. Hoboken, New Jersey: John Wiley \& Sons, Inc.

Etim, E. U. (2012). Estimation of pollution load from an industrial estate, south-western Nigeria. African Journal of Environmental Science and Technology, 6(2), 125-129.

Fatima, T., Rafiq watto, H. M. W., Sohail, M. M., Khan, M. A., Saleem, M. (2013). Assessing the Awareness of People about Industrial Air Pollution and Its Effects on Human Respiratory System. Asian Journal of Empirical Research 3(3), 298-307.

Foley, J. A., DeFries, R., Asner, G. P., Barford, C., Bonan, G., Carpenter, S. R., Chapin, F. S., Coe, M. T., Daily, G. C., Gibbs, H. K., Helkowski, J. H., Holloway, T., Howard, E. A., Kucharik, C. J., Monfreda, C., Patz, J. A., Prentice, I. C., Ramankutty, N., and Snyder, P. K. (2005). Global Consequences of Land Use. Science, 309 (5734), 570-574.

Fraj-Andrés, E., Martínez-Salinas, E., \& Matute-Vallejo, J. (2009). Factors Affecting Corporate Environmental Strategy in Spanish Industrial Firms. Business Strategy and the Environment, 18, 500-514.

Freeman, R. E. (2002). Stakeholder Theory of the Modern Corporation. In Donaldson, T. \& Werhane, P. (Eds), Ethical Issues in Business: A Philosophical Approach, Prentice Hall, Englewood Cliffs, NJ, pp. 38-48.

Freeman, R. E. and McVea, J. (2001). A Stakeholder Approach to Strategic Management, Darden Business School Working Paper, Vol 01-02.

Friedrich, S. (2002). Size and Measurement of the Informal Economy in 110 Countries around the World. Paper presented at a Workshop of Australian National Tax Centre, July 17, 2002, ANU, Canberra, Australia. Financing from the Doing Business project of the World Bank.

Goyal, S. K., Nema, P. and Devotta, S. (2008). Sustainable Industrial Development and Environment Protection: An Emerging Perspective. Environmental Progress, 27 (1), 5865.

Greenbaum, A \& Wellington, A. (2010). Environmental Law and Policy in the Canadian Context. Captus Press, Concord ON, 2010.

Hall, P. (1988). The Industrial Revolution in Reserve. The Planner. 74 (1), 15-19. 
Henriques, I., \& Sadorsky, P. (1999). The relationship between environmental commitment and managerial perceptions of stakeholder importance. Academy of Management Journal, 42, 87-99.

Hillary, R. (2000). Small and medium sized enterprises and environmental management systems: Experience from Europe. St. Galler Umwelt management Forum. London: Network for Environmental Management and Auditing.

Idemudia, U and Ite, U. E. (2006). Corporate-Community Relations in Nigeria's Oil Industry: Challenges and Imperatives. Corporate Social Responsibility and Environmental Management, 13, 194-206.

International Organization for Standardization (ISO) 26000 Project Overview, 2010.

Kadiri, W. (2001). Ogun State Regional Plan Draft: Agbara - Sango-Ota - Ifo - Isheri Sub region (Ogun and Lagos States).

Kadiri, W. (1992). Ota, in Onakomaiya, S., Oyesiku, K. and Jegede, F. (eds). (1992). Ogun State in Maps. Ibadan: Rex Charles Publication.

Kashem, A. Singh, B. R. (1999). Heavy metal contamination of soil and vegetation in the vicinity of industries in Bangladesh. Water, Air, \& Soil Pollution, 115(1-4), 347-361.

Kerbachi, R., Boughedaoui, M., Bounoue, L. and Keddam, M. (2006), Ambient air pollution by aromatic hydrocarbons in Algiers. Atmospheric Environment, 40, 3995 - 4003.

Kim, Y. M., Harrad, S. and Harrison, R. M. (2002), Levels and sources of Personal inhalation exposure to VOCs. Environ. Sci. Tech. 36, S 405 - S410.

Koc, M. (2015). Crisis of legitimacy and challenges for food policy. CFS/RCEA-Special Issue, 2(2), 17-22.

Kondracki, N. L., \& Wellman, N. S. (2002). Content analysis: Review of methods and their applications in nutrition education. Journal of Nutrition Education and Behavior, 34, 224-230.

Ladan, M. T. (2012). Review of NESREA Act 2007 and Regulations 2009-2011: A New Dawn in Environmental Compliance and Enforcement in Nigeria. LEAD Journal, 116-140.

Landajo, A., Arana, G., De Diego, A. Etxebarria, N., Zuloaga, O. and Amouroux, D. (2004). Analysis of heavy metal distribution in superficial estuarine sediments (estuary of Bilbao, Basque Country) by open-focused microwave-assisted extraction and ICP-OES. Chemosphere, (56)11, 1033-1041. 
Lewis, J. L. \& Sheppard, S. R. J. (2006). Culture and communication: can landscape visualization improve forest management consultation with indigenous communities? Landscape and Urban Planning, 77, 291-313.

Li, S., Long, C., Liu, F., Lee, S., Guo, Q., Li, R. \& Liu, Y. (2006). Herbs for medicinal baths among the traditional Yao communities of China. Journal of Ethnopharmacology, 108, 59-67.

Library of Congress - Federal Research Division (2008). Country profile: Nigeria. Retrieved May 15, 2015 from http://lcweb2.loc.gov/frd/cs/profiles/Nigeria.pdf

Lourdes, B and Floro, M. S. (2006). Labor Market Informalization, Gender and Social

Protection: Reflections on Poor Urban Households in Bolivia, Ecuador and Thailand, in Shahra Razavi and Shireen Hassim, eds. Gender and Social Policy in a Global Context: Uncovering the Gendered Structure of "the Social, pp. 193-216. New York: Palgrave Macmillan.

MacDonell, M., Morgan, K., and Newland, L. (2002). Integrating Information for Better Environmental Decisions. Environmental Science and Pollution Research, 9 (6), 359 368.

Magbagbeola, N. O. (2001). The Use of Economic Instruments for industrial pollution abatement in Nigeria: Application to the Lagos Lagoon". In Natural Resources use, the environment and sustainable development. Nigeria Economic society, University of Ibadan, Ibadan, Nigeria. Pp 535-556.

Marshall. (1998). Economic Instruments and the Business Use of Energy. Stationery Office, London.

Martinez-Romero, M. M., Castro-Ramirez, A. E., Macario, P. \& Fernandez, J. C. (2004). Use and availability of craft vines in the influence zone of the biosphere reserve Sian Kaan Quintana Roo, Mexico. Economic Botany, 58, 83-97.

Martley, E., Gulson, B. L., and Pfeifer, H. R. (2004). Metal concentrations in soils around the copper smelter and surrounding industrial complex of Port Kembla, NSW, Australia. Science of the Total Environment, 325 (1-3), 113-127.

McMartin, I., Henderson, P. J. and Nielsen, E. (1999). Impact of a base metal smelter on the geochemistry of soils of the Flin Flon region, Manitoba and Saskatchewan. Canadian Journal of Earth Sciences, 36 (2), 141-160.

McMartin, I., Henderson, P. J., Plouffe, A., and Knight, R. D. (2002). Comparison of Cu$\mathrm{Hg}-\mathrm{Ni}-\mathrm{Pb}$ concentrations in soils adjacent to anthropogenic point sources: examples from four Canadian sites. Geochemistry, 2 (1), 57-74. 
Medupin, C. \& Adedoyin K. S. L. (n.d.). National Open University of Nigeria: Environmental Protection Agencies Case Studies. Retrieved November 08, 2014 from http://www.nou.edu.ng/NOUN_OCL/pdf/edited_pdf3/ESM\%20405\%20EPA.pdf

Meier, G. M. and Rauch, J. E. (2005). Leading Issues in Economic Development ( $8^{\text {th }}$ ed.). New York: Oxford University Press. pp. 371-375.

Menon, A., \& Menon, A. (1997). Environpreneurial marketing strategy: the emergence of corporate environmentalism as market strategy. Journal of Marketing, 61, 51-67.

Mir, M., J. M. Estela, J. M., and Cerd, V. (2004). Application of flowing stream techniques to water analysis: part III. Metal ions: alkaline and alkaline-earth metals, elemental and harmful transition metals, and multi elemental analysis. Talanta, 63 (2), 201-223.

Nadal, M. Mari, M., Schumacher, M., and Domingo, J. L. (2009). Multi-compartmental environmental surveillance of a petrochemical area: levels of micro pollutants. Environment International, 35(2), 227-235.

National Economic Empowerment and Development Strategy (2004), Nigeria National Planning Commission. Available at: http://siteresources.worldbank.org/INTPRS1/Resources/Nigeria_PRSP(Dec2005).pdf (Accessed May 10, 2015).

National Environmental Standards and Regulations Enforcement Agency (NESREA). Available at: http://www.nesrea.gov.ng/about/index.html (Accessed March 16, 2015).

National Environmental Regulations (2010) Schedule XIX

Nduka, J. K. and Orisakwe, O. E. (2009). Effect of Effluents from Warri Refinery Petrochemical Company on Water and Soil Qualities of "Contiguous Host" and "Impacted on Communities" of Delta State, Nigeria. The Open Environmental Pollution \& Toxicology Journal, 1, 11-17.

Ngwake (2008) Environmental Responsibility and Firm Performance: Evidence from Nigeria. World Academy of Science, Engineering and Technology, Volume 22.

Nwachukwu, A. N., Ugwuanyi, J. U. (2010). Air pollution and its possible health effects on rural dwellers in Rivers State, Nigeria. Afr. J. Phys. 3:217-240.

Nuissl, H., Hearse, D., Lanzendorf, M., Wittmer, H. (2009). Environmental impact assessment of urban land use transitions-A context-sensitive approach. Land Use Policy, 26, 414-424.

Obateru, O. I. (2004). The Genesis and Future of Abuja. Ibadan: Penthouse Publications (Nig). 
Odesanya, B. O., Ajayi, S. O., Shittu, M. \& Oshin, O. (2012). Use of Industrial Pollution

Projection System (IPPS) to estimate pollution load by sector in two industrial estates in Ogun State, Western Nigeria. International Journal of Scientific \& Engineering Research, $3(10)$.

Ogundele, O. J. K. (2005). Management and Organisations: Theory and Practice. Molofin Nominee, Lagos.

Ogun State Government of Nigeria (2008). The Ogun State Regional Development Plan (20052025). Abeokuta: Office of the Governor, Ogun State.

Ogun State Government of Nigeria Annual Report (2014).

Ojiodu, C. C. (2013). Ambient Volatile Organic Compounds (VOCs) pollution in Isolo Industrial Area of Lagos State, Southwestern - Nigeria. Ethiopian Journal of Environmental Studies and Management, 6(6), 688-697.

Okafor, E. E., Hassan, A. R. and Doyin-Hassan, A. (2008). Environmental Issues and

Corporate Social Responsibility: The Nigeria Experience. J. Hum. Ecol., 23(2), 101-107.

Oketola, A. A., and Osibanjo, O. (2007). Estimating Sectoral Pollution Load in Lagos by Industrial Pollution Projection System (IPPS). Science of the Total Environment 377, 23: $125-41$.

Okorodudu-Fubara, M. (2012). Country Report: Nigeria Legal Developments, 2009-2011. IUCN Academy of Environmental Law e-Journal Issue, 1.

Olayinka, O. S. and Abdullahi, S. A. (2009). An Overview of Industrial Employees' Exposure to Noise in Sundry Processing and Manufacturing Industries in Ilorin Metropolis, Nigeria. Industrial Health, 47, 123-133.

Olusimbo, K. I. \& Nwachukwu, C. C. (2010). Areas of dissatisfaction with primary health care services in Government owned health facilities in a semi urban community in Nigeria. Journal of Rural and Tropical Public Health, 9, 19-23.

Onwuegbuzie, A. J. (2009). A Qualitative Framework for Collecting and Analyzing Data in Focus Group Research. International Journal of Qualitative, 8(3).

Orubu, C. O., Odusola, A., Ehwarieme, W. (2004). The Nigerian oil industry: environmental diseconomies, management strategies and the need for community involvement. Journal of Human Ecology, 16(3), 203-214.

Osuji, L. C, Avwiri, G. O. (2005). Flared Gases and Other Pollutants Associated with Air Quality in Industrial Areas of Nigeria: An Overview. Chem. Biodivers, 2, 1-8. 
Oyelakin-Oyelaran, A. (1997). Nnewi, an emergent industrial cluster in Nigeria. Technopol Publishers, Ibadan, volume 1.

Oyinloye, M. A. (2015). Environmental Pollution and Health Risks of Residents Living Near Ewekoro Cement Factory, Ewekoro, Nigeria World Academy of Science, Engineering and Technology. International Journal of Environmental, Chemical, Ecological, Geological and Geophysical Engineering, 9 (2).

Parikh, J. K., Sharma, V. K., Gosh, U., and Panda, M. K. (1995). Trade and Environment Linkages: a case study of India, Indira Gandhi Institute of Development.

Pérez-Sirvent, C., García-Lorenzo, M. L., Martínez-Sánchez, M. J., Navarro, M. C., Marimón, J., Bech, J. (2007). Metal-contaminated soil remediation by using sludge of the marble industry: toxicological evaluation. Environment International, 33 (4), 502-504.

Platform (2011). Shell is abusing human rights in Nigeria. But who can stop them?

http://platformlondon.org/2011/10/17/shell-is-abusing-human-rights-in-nigeria-but-whocan-stop-them/

Puga, D. \& Venables, A. (1996). The spread of industry spatial agglomeration in economic development. Centre for Economic Performance Discussion Paper.

Rawlins, B. G., Lark, R. M., Webster, R., and O'Donnell, K. E. (2006). The use of soil survey data to determine the magnitude and extent of historic metal deposition related to atmospheric smelter emissions across Humberside, UK. Environmental Pollution, 143 (3), 416-426.

Rumcher, K., Spickett, J., Bulsara, M., Philip, M. and Stocks, S. (2004). Association of domestic exposure to Volatile Organic Compounds with Asthma in young children. Thorax. 59, $746-751$.

Saha, M., \& Darnton, G. (2005). Green companies or green companies: are companies really green, or are they pretending to be? Business and Society Review, 110(2), 117-157.

Salau, T., Lawanson, T. and Odumbaku, O. (2013). Amoebic Urbanization in Nigerian Cities (The Case of Lagos and Ota). International Journal of Architecture and Urban Development, 3 (4).

Samet, J. M. (2000). National Morbidity, Mortality, and Air Pollution Study. Health Effects Institute, Boston.

Scott, A. (1998). Environmental impact of small scale industries in Third World. UK Global Environmental Change Programme, ESRC, Knowledge Base. 
Shrivastava, P. (1995). Industrial/Environmental Crises and Corporate Social Responsibility. The Journal of Socio-Economics, 24 (1), 211-227.

Smith, M.A. \& Kemp, R. (1998). Small Firms and the Environment 1998: A Grounded Report. Groundwork, Birmingham.

Sommer, B., \& Sommer, R. (2002). A Practical Guide to Behavioural Research - Tools and Techniques. (5th ed.). New York, Oxford University Press Inc.

Steinke, I. (2004). Quality criteria in qualitative research. A companion to qualitative research, 184-190. London: Sage Publications.

Suh, H. H., Bahadori, T., Vallarino, J. and Spengler, J. D. (2000). Criteria for air pollutants and toxic air pollutants. Environmental Health Perspective. 108 (Suppl. 4), 625 - 633.

The North American Mosaic (2008). An Overview of Key Environmental Issues. Commission for Environmental Cooperation. pp. 44-46. http://www3.cec.org/islandora/en/item/2349north-american-mosaic-overview-key-environmental-issues-en.pdf

Topp, L., Barker, B. \& Degenhardt, L. (2004). The external validity of results derived from ecstasy users recruited using purposive sampling strategies. Drug and Alcohol Dependence, 73, 33-40.

Ugwuanyi, J. U., Obi, F. C. (2002). A survey of Health Effects of Air Pollution on Peasant Farmers in Benue State, Nigeria. Int. J. environ. Stud., 59. Gordon and Breach Sci. Publishers, U.K.

UNDESA (United Nations Department of Economic and Social Affairs/Population Division). (2011). World Urbanization Prospects.

UNIDO (2011) Independent UNIDO Country Evaluation, Federal Republic of Nigeria. Available at:http://www.unido.org/fileadmin/user_media/About_UNIDO/Evaluation/Country_Repo rts/Nigeria_E-Book.pdf (Accessed March 10, 2015).

Walker, M., Nunez, J., Walkingstick, M. \& Banack, S. A. (2004). Ethnobotanical investigation of the Acjachemen clapperstick from blue elderberry, Sambucus mexicana (Caprifoliaceae). Economic Botany, 58, 21-24.

Wen, X. (n.d.). Point Sources of Pollution: Local Effects and its Control - Industrial Pollution. Encyclopedia of Life Support System, Vol. 1.

WHO (2004a). Health aspects of air pollution. Results from WHO project "Systematic review of health aspects of air pollution in Europe". World Health Organization Regional Office for Europe 2004. http//www.euro.who.int/document/E83080.pdf 
WHO (2005). Air Quality Guidelines - Global Update. 2006, Copenhagen.

WHO (2007). New Country-by-Country Data Show in Detail the Impact of Environmental

Factors on Health. Geneva, Switzerland: World health Organization. World Health Organisation. Global estimates of burden of diseases caused by environmental and occupational risks. http://www.who.int/quantifying_ehimpacts/global/urbair/en/

Wong, V., Turner, W., \& Stoneman, P. (1996). Marketing strategies and market prospects for environmentally-friendly consumer products. British Journal of Management, 7, 263281.

World Bank (Report) "Republic of Nigeria - Health Care Cost, Financing and Utilization," 1991.

Zhen, L., Zoebisch, M. A., Chen, G. \& Feng, Z. (2006). Sustainability of farmers' soil fertility management practices: A case study in the North China Plain. Journal of Environmental Management, 79, 409-419. 